Faculdade de Zo ot ec nia e Engenharia de Al imentos

\title{
AVALIAÇÃO DE MÉTODOS PARA DETERMINAÇÃO DA DIGESTIBILIDADE APARENTE UTILIZANDO FARELO DE VAGEM DE ALGAROBA (Prosopis juliflora (Swartz) D.C.) EM EQÜINOS
}

\section{Rosane Barros da Silva Stein}

D issertação de M estrado depositada na Seção de PósG raduação da Faculdade de Zootecnia e Engenharia de A lim entos da U SP, com o parte dos requisitos para a obtenção do $\mathrm{T}$ ílu de $\mathrm{M}$ estre em Zootecnia, na área de concentração: Q ualidade e P rodutividade A nim al

Orientador: Prof. Dr. Luiz Roberto Aguiar de Toledo 


\section{FICHA CATALOGRÁFICA}

preparada pela

Biblioteca da Faculdade de Zootecnia e Engenharia de Alimentos da Universidade de São Paulo

Stein, Rosane Barros da Silva

S818a Avaliação de métodos para determinação da digestibilidade aparente utilizando farelo de vagem de algaroba (Prosopis juliflora (Swartz) D.C.) em eqüinos / Rosane Barros da Silva Stein. - Pirassununga, 2002. Dissertação (Mestrado) Faculdade de Zootecnia e Engenharia de Alimentos Universidade de São Paulo. Departamento de Zootecnia. Área de concentração: Qualidade e Produtividade Animal. Orientador: Prof. Dr. Luiz Roberto Aguiar de Toledo.

Unitermos: 1. Digestibilidade 2. Eqüinos, nutrição 3. Suplementos alimentares para animal I. Título. 
“...- $\mathcal{N a ̃ o ~ s e ~ g l o r i e ~ o ~ s a ́ b i o ~ n a ~ s a b e d o r i a , ~ . . . ; ~ m a s ~ o ~ q u e ~ s e ~}$ gloriar, glorie-se nisto: em me confecer e saber que sou o Senhor e faço misericórdia, juízo e justiça na terra; porque destas coisas me agrado, diz o Senhor." Bíblia Sagrada. Jeremias 9:23 e 24

\section{Dedico}

"Ó profundidade da riqueza, tanto da sabedoria como do conhecimento de Deus! Quão insondáveis são os teus juízos, e inescrutáveis, os teus caminhos! Quem, pois, confeceu a mente do nosso Senhor? Ou quem foi o seu conselheiro? Ou quem primeiro deu a ele para que the venha a ser restituido? Por que dEle, e por meio dEle, e para Ele são todas as coisas. A E Le, pois, a glória eternamente. Amém." Bíblia Sagrada. Romanos 11:33 a 36 
"Tudo em volta vai mudando: estações que vem, se vão. Poucas coisas permanecem aquecendo o coração..." Mas nós, “...estaremos sempre juntos, e juntos vamos ser, pra sempre, amigos no Senhor. Vamos viver, pra sempre, ligados pelo amor." Trecho da música "Amigos para sempre": Coral IASP:

\section{Dedico}

Ao meu querido esposo, Sérgio, e a toda família BARROS, por me ensinarem os mais nobres princípios: viver com Deus, e em família. Especialmente à minha avó Gisélia, exemplo de vida o qual almejo seguir. Amo vocês. 


\section{AGRADECIMENTOS}

Sobretudo, “Àquele que é poderoso para fazer infinitamente mais do que tudo que pedimos ou pensamos,..., a Deus seja a glória,...., para todo o sempre. Amém”. Bíblia Sagrada. Efésios 3:20.

A Sérgio, meu querido esposo e companheiro, por seu amor incondicional demonstrado em todas as etapas desse caminho.

Aos meus pais, Rovenate e Zélia, por tudo que já fizeram para que chegasse até aqui, educando, confiando, apoiando, e, acima de tudo, amando.

Aos saudosos companheiros do trabalho duro, que dividiram dias e noites de experimento e folia sem os quais este trabalho se tornaria muito mais árduo. A vocês da rural, Ana, Anderson, Chiara, Edson, João Batista, João Soares, Liliane, Silvana, Tiago, Viviane e Mírio, um beijo muito carinhoso.

Aos funcionários e estagiários do setor de eqüinos da UFRRJ, em especial Luciano, Zezinho e Max, pela indispensável colaboração durante todo o trabalho de campo.

Ao meu prezado orientador Prof ${ }^{\circ}$ Dr. Luiz Roberto Aguiar de Toledo, pelos ensinamentos, compreensão, paciência e toda confiança depositada na minha pessoa.

Ao querido Prof ${ }^{\circ}$ Dr. Fernando Queiroz de Almeida - UFRRJ, fonte de inspiração para o meu trabalho, por ter me desvendado este caminho, pelo apoio e acompanhamento fundamentais.

Aos funcionários do Laboratório de Bromatologia e das Agrárias, em especial, Rose e Rosilda e à Prof ${ }^{a}$. Dr ${ }^{\mathrm{a}}$ Catarina Abdalla Gomide, não somente pelo auxílio, mas pela amizade e estímulo em todos os momentos. 
À Rosane, Liamara, e à família Domingos que me acolheram em um dos períodos mais difíceis deste trabalho.

Às amigas do quarto A6, Denise, Tatiane e Käthery, com as quais dividi alegrias, tristezas, material, miojo e tudo mais!!!!! Foi ótimo morar e poder contar com vocês.

Aos queridos professores Dr. Paulo Henrique Mazza e Dr. César Gonçalves de Lima por se interessarem e se empenharem em análises estatísticas inovadoras que tanto enriqueceram este trabalho.

Ao prezado prof $^{\circ}$ Dr. Rubens Nunes, pela dedicação e preciosa orientação na parte econômica deste trabalho.

A RIOCON ${ }^{\circledR}$ por ter fornecido o farelo de vagem de algaroba para este estudo, e por ser uma empresa arrojada, impressionando-nos, incentivando-nos e inovando o desenvolvimento técnico do país. Especialmente ao técnico e administrador José Antônio, por todo o apoio concedido.

À FAPESP pela concessão da bolsa de estudos e auxílio financeiro em toda pesquisa.

À FZEA por ter me dado a oportunidade de me aperfeiçoar nos estudos.

A querida Lêlê, que me mostrou dia a dia que fidelidade e amizade são virtudes a serem demonstradas em todo e qualquer momento.

A todos que direta ou indiretamente contribuíram para esta vitória em minha vida, 


\section{SUMÁRIO}

Página

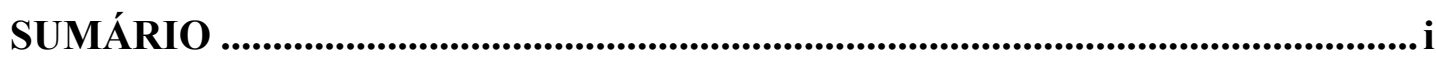

LISTA DE FIGURAS ...........................................................................................ii

LISTA DE TABELAS ..................................................................................

LISTA DE ABREVIATURAS ........................................................................... vi

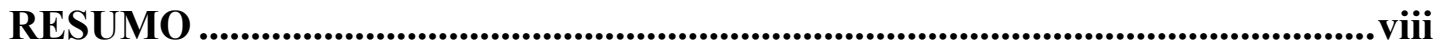

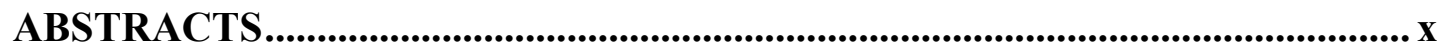

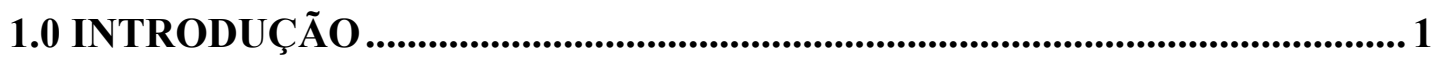

2.0 REVISÃO BIBLIOGRÁFICA.................................................................... 3

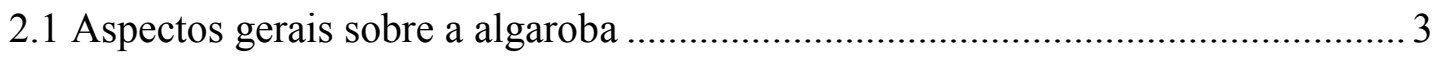

2.2 Algaroba: digestibilidade e viabilidade econômica ............................................... 5

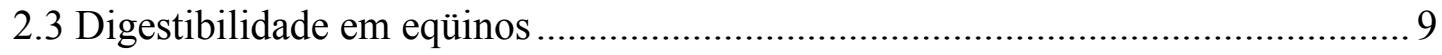

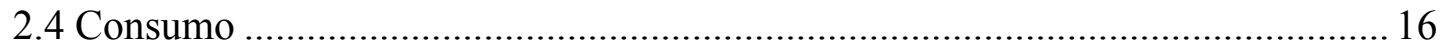

2.5 Estimativa de digestibilidade através de indicadores internos .......................... 18

3.0 MATERIAL E MÉTODOS................................................................... 21

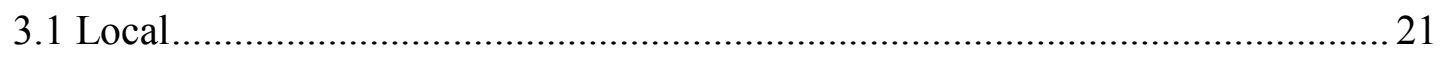

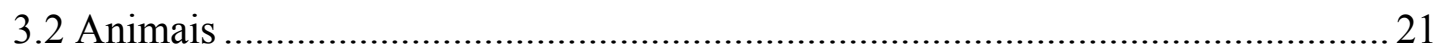

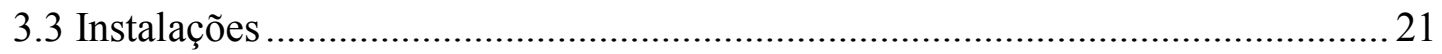

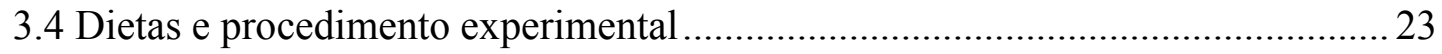

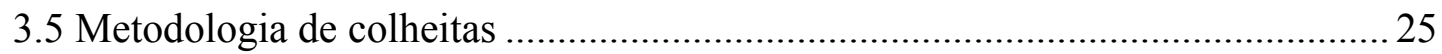

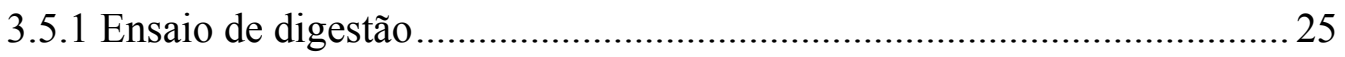

3.5.2 Viabilidade econômica da substituição ................................................... 26

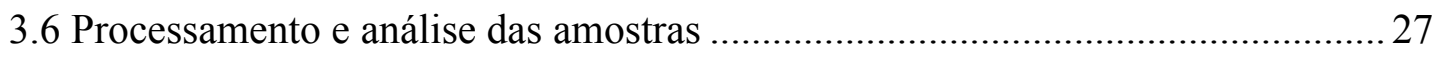

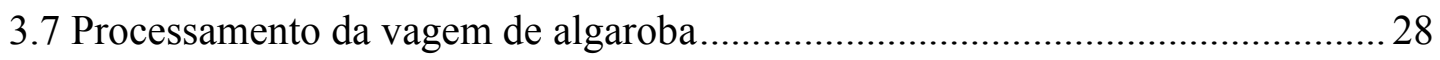

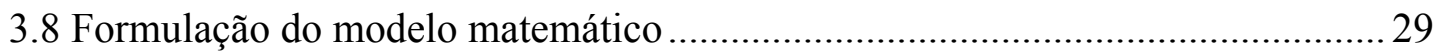

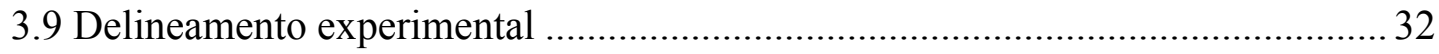

4.0 RESULTADOS E DISCUSSÃO .................................................................... 34

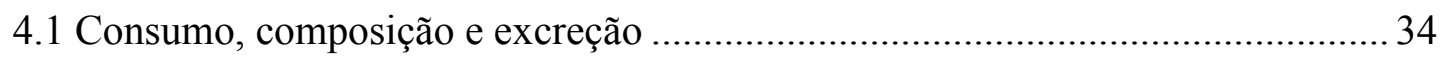

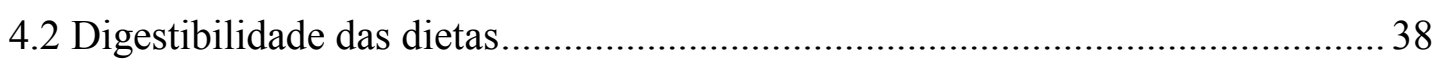

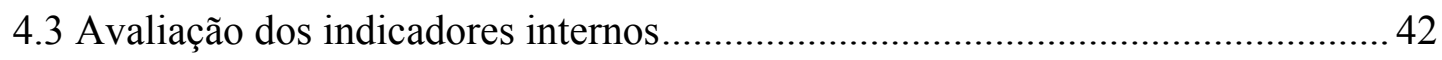

4.4 Viabilidade econômica da substituição MDPS por FVA..................................... 49 


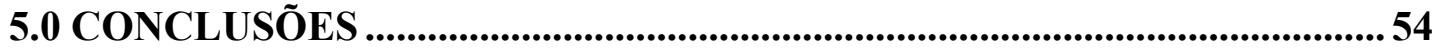

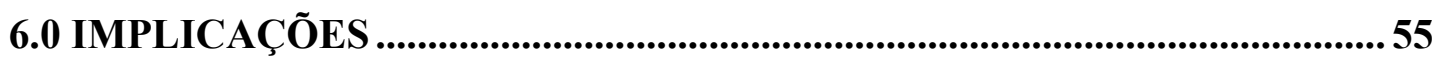

ANEXO A .......................................................................................................................56

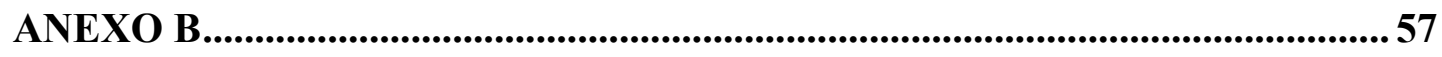

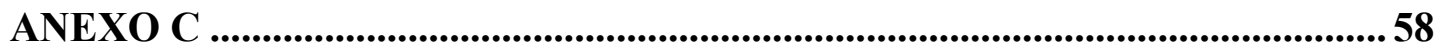

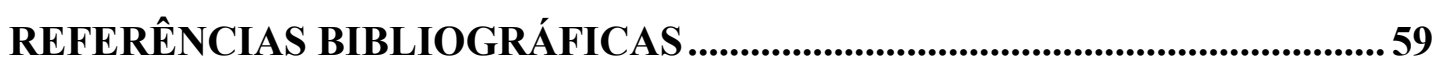

APÊNDICE 1

APÊNDICE 2

APÊNDICE 3 


\section{LISTA DE FIGURAS}

\section{Página}

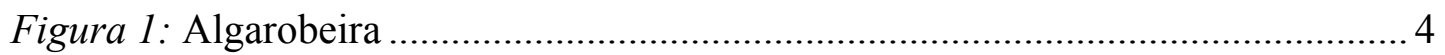

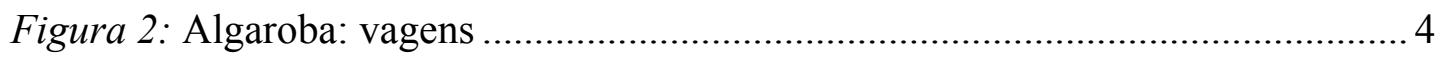

Figura 3: Égua Mangalarga Marchador - Quarela, 18 anos, Bloco IV..................... 22

Figura 4: Égua Mangalarga Marchador - Felina, 5 anos, Bloco II.......................... 22

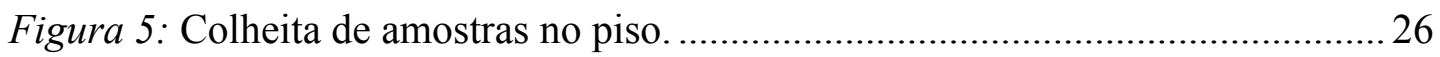

Figura 6: Comportamento dos nutrientes FDA e EB excretados nas fezes de éguas consumindo feno de Coast cross e concentrado (60:40\%) com diferentes níveis de FVA em substituição ao MDPS.

Figura 7: Comportamento dos coeficientes de digestibilidade aparente das fibras em éguas consumindo feno de Coast cross e concentrado (60:40\%) com diferentes níveis de FVA em substituição ao MDPS.

Figura 8: Resposta do CDEB em éguas consumindo feno de Coast cross e concentrado (60:40\%) com diferentes níveis de FVA em substituição ao MDPS.

Figura 9: Curvas de regressão dos vieses dos indicadores (CDMS colheita total CDMS indicador) contra os CDMS estimados por cada um deles $(p=0,0001)$. FDAi: $y=0,9862 x-48,523, R^{2}=0,5453$. CELi: $y=1,2104 x-58,862, R^{2}=$ 0,7389. CIA: $y=0,6934 x-29,337, R^{2}=0,2813$.

Figura 11: Cotações de preço ao produtor do milho (grão) ao longo de 10 anos, deflacionados pelo IGP-M. Elaborado a partir de dados obtidos da Fundação Getúlio Vargas - FGV - Agroanalysis (2002).

Figura 12: Sazonalidade dos preços do milho demonstrado por regressão linear. Método utilizado: mínimos quadrados ordinários onde a variável dependente é o preço do milho e as variáveis independentes são 12 variáveis binárias $(0,1)$ representativas dos meses do ano. Elaborado a partir de dados (10 anos) obtidos da FGV - Agroanalysis (2002). 


\section{LISTA DE TABELAS}

Página

Tabela 1: Valores de coeficientes de digestibilidade aparente total publicados: autor (es), ano de publicação, dieta utilizada e categoria animal. 15

Tabela 2: Composição centesimal dos ingredientes das rações experimentais T1, T2, T3 e T4 com os respectivos níveis de substituição do MDPS pelo FVA: $0,33,66$ e $100 \%$.

Tabela 3: Composição química das rações experimentais T1, T2, T3 e T4 com os respectivos níveis de substituição do MDPS pelo FVA: 0, 33, 66 e 100\%... 23

Tabela 4: Composição química dos ingredientes utilizados (\% na MS). 24

Tabela 5: Médias de peso vivo (kg) e consumo (kg MS/dia, \% PV e peso metabólico - PM) de éguas alimentadas com feno de Coast cross e concentrado (60:40\%) com diferentes níveis de substituição do MDPS pelo FVA.

Tabela 6: Composição química média fecal de éguas consumindo feno de Coast cross e concentrado $(60: 40 \%)$ com diferentes níveis de FVA em substituição ao MDPS.

Tabela 7: Coeficientes de digestibilidade aparente (CD) da MS, MO, PB, HCEL, FDN, FDA e EB de éguas consumindo feno de Coast cross e concentrado (60:40\%) com diferentes níveis de FVA em substituição ao MDPS. 38

Tabela 8: Coeficientes de digestibilidade aparente da matéria seca (CDMS) estimados por meio da colheita total de fezes (CT) e dos indicadores: celulose indigestível (CELi), fibra em detergente ácido indigestível (FDAi) e cinza insolúvel em ácido (CIA), em éguas alimentadas com feno de Coast cross e concentrado $(60: 40 \%)$ com diferentes níveis de substituição do MDPS pelo FVA. 42

Tabela 9: Teor de indicadores na dieta total e em seus componentes (\% na MS).

Tabela 10: Comparação das estimativas de CDMS por indicadores internos através da análise do viés (CDMS indicador - CDMS colheita total de fezes). 
Tabela 11: Comparação das regressões obtidas a partir do viés de indicadores (CDMS indicador - CDMS colheita total de fezes) para avaliação do quesito robustez. 46

Tabela 12: Custo de alimentos e rações para eqüinos utilizando o FVA em substituição ao MDPS. 49

Tabela 13: Teor de nutrientes (\% na MS) e preço do MDPS e do milho. 66

Tabela 14: Preços e relações encontradas para MDPS e milho em revendedores de insumos no estado de São Paulo, na $2^{\text {a }}$ quinzena de julho de 2002. 67

Tabela 15: Taxa de câmbio R\$/US\$ comercial - venda média semanal, nos meses de junho e julho de 2002.*

Tabela 16: Composição química média fecal de éguas consumindo feno de Coast cross e concentrado $(60: 40 \%)$ com diferentes níveis de FVA em substituição ao MDPS (colheita parcial de fezes). 68

Tabela 17: Média dos coeficientes de digestibilidade (\%) da MS (CDMS), MO (CDMO), PB (CDPB), FDN (CDFDN), FDA (CDFDA), HCEL (CDHCEL) e EB, (CDEB) de éguas alimentadas com feno de Coast cross e concentrado (60:40\%) com diferentes níveis de FVA em substituição MDPS, determinados por colheita total de fezes e indicadores internos. 69 


\section{LISTA DE ABREVIATURAS}

Ac - Concentração do indicador no concentrado

Af - Concentração do indicador no feno

Afe - Concentração do indicador nas fezes

$\mathrm{Ai}$ - Concentração do indicador ingerido

As - Concentração do indicador nas sobras

AGV - Ácidos graxos voláteis

Cc - Consumo de concentrado

CD - Coeficiente de digestibilidade

CELi - Celulose indigestível

Cf - Consumo de feno

CIA - Cinza Insolúvel em Ácido

CMS - Consumo de matéria seca

CRN - Consumo Real de Nutrientes

CT - Colheita total de fezes

EB - Energia Bruta

ED - Energia Digestível

FB - Fibra Bruta

FDA - Fibra em Detergente Ácido

FDAi - Fibra em Detergente Ácido indigestível

FDN - Fibra em Detergente Neutro

FVA - Farelo de Vagem de Algaroba

Ind.exc - Quantidade de indicador excretado

Ind.fe - Quantidade de indicador nas fezes

Ind.i - Quantidade de indicador ingerido

MDPS -Milho Desintegrado com Palha e Sabugo

MO - Matéria Orgânica

MS - Matéria Seca

Nc - Quantidade de nutriente do concentrado

$\mathrm{Nf}$ - Quantidade de nutriente do feno

Nfe - Quantidade de nutriente das fezes 
Ns - Quantidade de nutriente das sobras

PB - Proteína Bruta

PV ${ }^{0,75}$ - Peso Metabólico

PV - Peso Vivo

S - Sobras

VAT - Vagem de algaroba triturada 


\section{RESUMO}

STEIN, R.B.S. Avaliação de métodos para determinação da digestibilidade aparente utilizando farelo de vagem de algaroba (Prosopis juliflora (Swartz) D.C.) em eqüinos. 69 p. il. 2002. Dissertação de Mestrado - Faculdade de Zootecnia e Engenharia de Alimentos - Universidade de São Paulo.

Utilizando 16 éguas adultas da raça Mangalarga Marchador, com idade entre 3,5 a 18,4 anos, e peso médio de $394,80 \pm 46,22 \mathrm{~kg}$, determinaram-se os coeficientes de digestibilidade aparente (CD) da matéria seca (MS), matéria orgânica (MO), proteína bruta (PB), fibra em detergente ácido (FDA), fibra em detergente neutro $(F D N)$, hemicelulose (HCEL) e energia bruta (EB), e avaliou-se a viabilidade econômica de dietas contendo farelo de vagem de algaroba (FVA) em substituição ao milho desintegrado com palha e sabugo - rolão de milho (MDPS). Foram comparadas quatro metodologias para estimar os CDMS: colheita total de fezes (CT) e o uso dos indicadores internos: celulose indigestível (CELi), fibra em detergente ácido indigestível (FDAi) e cinza insolúvel em ácido (CIA). As dietas foram isoprotéicas e isocalóricas, compostas de feno de Coast cross (Cynodon dactylon cv. Coast cross) e concentrado (60:40\%), e a variação ocorreu nos níveis de substituição do MDPS pelo FVA, os quais foram: 0, 33, 66 e 100\%. O delineamento experimental adotado foi em blocos casualizados com 4 repetições em cada tratamento. A avaliação das estimativas do CDMS pelos indicadores foi efetuada através de um modelo considerando o viés, ou seja, a diferença entre CDMS estimado pelo indicador e pela CT. Não ocorreu efeito de bloco para nenhuma das variáveis estudadas. O consumo não foi afetado pelos tratamentos, obtendo-se valores médios de 1,8\% PV (peso vivo), 7,02 kg MS/dia e 79,84 g MS/ $\mathrm{kg} \mathrm{PV}{ }^{0,75}$. A substituição afetou quadraticamente a excreção de FDA e EB nas fezes $(p<0,05)$. Os CDMS, CDMO CDPB e CDHCEL não mostraram diferenças entre os tratamentos. As médias calculadas foram 49,19\% (CDMS), 50,19\% (CDMO), 56,89\% (CDPB) e 
35,46\% (CDHCEL). Observou-se efeito linear decrescente para o CDFDN ( $\mathrm{p}=$ $0,0105)$, e efeito quadrático para os CDFDA $(\mathrm{p}=0,0468)$ e para o CDEB $(\mathrm{p}=$ 0,0147) em função dos níveis de substituição do MDPS pelo FVA. De acordo com as equações obtidas, o ponto máximo de digestibilidade para a FDA foi alcançado com $22,27 \%$ de substituição, enquanto para FDN e EB, com 0\% de substituição do MDPS pelo FVA. Entre os indicadores avaliados o FDAi foi o de parâmetros mais acurados. Com respeito à precisão, não foram observadas diferenças entre os indicadores $(\mathrm{p}<$ 0,05). Sobre robustez, as estimativas da FDAi e da CELi foram afetadas pelo consumo de matéria seca e pelo próprio CDMS, ao passo que a CIA foi afetada apenas pelo CDMS $(p<0,05)$. As taxas de recuperação calculadas foram 98,49, 94,49 e 144,5\% para a FDAi, CELi e CIA, respectivamente, e apenas a da FDAi não diferiu de $100 \%(\mathrm{p}<0,05)$. A classificação dos indicadores em função dos conceitos de avaliação utilizados (acurácia, precisão e robustez) foi FDAi > CIA > CELi. O custo das rações aumentou em 4,53, 10,64 e 11,60\% para os níveis de 33, 66 e 100\% de substituição, em relação ao tratamento isento de FVA. A viabilidade econômica da substituição do MDPS pelo FVA ocorre desde que o seu preço/kg não ultrapasse $85,95 \%$ do preço/kg do MDPS ou 70,09\% do preço/kg do milho grão.

Palavras chaves: Digestibilidade aparente, eqüinos, indicadores, Prosopis juliflora, viabilidade econômica. 


\begin{abstract}
S
STEIN, R.B.S. Determination of apparent digestibility evaluation methods in equines, using mesquite pod meal (Prosopis juliflora (Swartz) D.C.). 69 p. il. 2002. Dissertação de Mestrado. Faculdade de Zootecnia e Engenharia de Alimentos - Universidade de São Paulo.
\end{abstract}

By Rosane Barros da Silva Stein

Dr. Luiz Roberto Aguiar de Toledo, Major professor.

Sixteen mares of the Mangalarga Marchador breed, ageing from 3.5 to 18.4 years, weighting $394.80 \pm 46.22 \mathrm{~kg}$ were used. The apparent digestibility coefficients (CD) of dry matter (MS), organic matter (MO), crude protein (PB), acid detergent fiber (FDA), neutral detergent fiber (FDN), hemicellulose (HCEL) and gross energy (EB) were determined. The economic viability of the diets with mesquite pod meal (FVA) substituting corn and cob meal (MDPS) was evaluated. Four methods to estimate CDMS were compared: total feces collection (CT) and the use of internal markers: indigestible cellulose (CELi), indigestible acid detergent fiber (FDAi) and acid insoluble ash (CIA). The diets were isoproteic and isocaloric and were composed by Coast cross (Cynodon dactylon cv. Coast cross) hay and concentrate (60:40\%). The variation occurred on the level of substitution of MDPS by FVA: 0, 33, 66 and 100\%. A randomized complete blocks experimental design with 4 replications per treatment was adopted. The CDMS evaluation estimated by the markers was made by a model considering the bias, i.e., the difference between CDMS estimated by marker and by CT. Blocks did not affect significantly any studied variables. The intake was not affected by the treatments, averaging $1.8 \% \mathrm{PV}$ (body weigh), $7.02 \mathrm{~kg} \mathrm{MS} /$ day, $79.84 \mathrm{~g} \mathrm{MS} / \mathrm{kg}$ PV ${ }^{0.75}$. The substitution had a second-degree effect on excretion of FDA and EB in feces $(p<0.05)$. The CDMS, CDMO, CDHCEL and CDPB did not differ between the treatments. The averages 
were $49.19 \%$ (CDMS), 50.19\% (CDMO), 56.89\% (CDPB), and 35.46\% (CDHCEL). The decrease linear effect for CDFDN ( $p=0.0105$ ), and second-degree effect for CDFDA $(p=0.0468)$ and for CDEB $(p=0.0147)$, was observed in function of the substitution. According of the equations, the max point of digestibility to FDA was obtained with $22.27 \%$ of substitution, however to FDN e EB, was obtained with $0 \%$. Between the evaluated markers, FDAi was more accurate. Considering precision, no differences were observed between markers $(p<0.05)$. On robustness, FDAi and CELi estimatives were affected by dry matter intake and by its own CDMS, whereas CIA's estimative were affected only by CDMS $(p<0.05)$. Markers recoveries were 98.49, 94.49 and $144.5 \%$ for FDAi, CELi e CIA, respectively and, only the FDAi recovery did not differ from $100 \%(p<0.05)$. The ranking of the markers by the evaluation of the concepts (accuracy, precision and robustness) was FDAi $>$ CIA $>$ CELi. The concentrate cost increased in $4.53,10.64$ and $11.60 \%$ for the substitution levels of 33, 66 and 100\%, respectively, compared to the diets without FVA. The economic viability of substitution of MDPS by FVA occurs since its price $/ \mathrm{kg}$ is not over $85.95 \%$ of the MDPS's price $/ \mathrm{kg}$ or $70.09 \%$ of the corn's price $/ \mathrm{kg}$.

Keywords: Apparent digestibility, equine, markers, economic viability, Prosopis juliflora. 


\subsection{INTRODUÇÃO}

A alimentação e exploração animal na região nordeste do Brasil encontra barreiras para seu desenvolvimento devido às adversidades de climas característicos daquela região. $\mathrm{Na}$ estação seca, as altas temperaturas e baixos índices pluviométricos durante o ano são características dos climas árido e semi-árido, e prejudicam a produção de alimentos para os rebanhos.

Alimentos comumente utilizados em regiões de clima mais ameno (sul e sudeste, por exemplo) nem sempre atingem níveis adequados de produção nos climas quentes. A utilização de recursos, como irrigação, torna a produção animal, por vezes, inviável economicamente, principalmente em criações de pequena escala.

Devido a esses fatores, a utilização de alimentos alternativos que sejam adaptados, capazes de se desenvolverem e produzirem nutrientes a baixo custo, se torna relevante para o desenvolvimento da pecuária nestas regiões.

A algarobeira é uma leguminosa arbórea do gênero Prosopis introduzida no Brasil na região de Pernambuco desde a década de 40 , onde obteve desenvolvimento verdadeiramente animador. As sementes eram oriundas do Peru, que há muito utilizavam-na como recurso alimentar na criação animal (GOMES, 1961). Seu valor nutritivo concentra-se nas vagens (frutos), de onde se obtém rica fonte de proteínas e carboidratos, possuindo valor energético comparável ao milho. É encontrada em todo o norte e nordeste Brasileiro, desenvolvendo-se com invejável vigor desde praças até fazendas que se beneficiam de suas riquezas nutricionais na criação animal.

A literatura relata inúmeros trabalhos sobre a utilização da vagem de algaroba na alimentação para ruminantes, aves, suínos e coelhos, contudo não existem trabalhos se referindo ao uso desta fonte na alimentação de eqüinos.

A criação destes animais obrigatoriamente passa pela qualidade do manejo nutricional bem como o custo de produção. Daí a importância de se fornecer alimentos nutricionalmente adequados à espécie, que proporcionem bom 
desenvolvimento e, ao mesmo tempo, que sejam adaptados às limitações financeiras e edafoclimáticas da região criadora.

No estudo da nutrição eqüina, a determinação da digestibilidade é de grande importância para avaliação de alimentos usados nas dietas. A colheita total de fezes é o método direto utilizado e considerado o mais confiável, entretanto, é um processo dispendioso e demorado. Apesar disso, existe interesse em estabelecer métodos simples que possam contornar as dificuldades inerentes ao método tradicional.

A estimativa da digestibilidade dos nutrientes pode também ser feita através de métodos indiretos que se baseiam no uso de indicadores que, sendo ingeridos, devem ser totalmente recuperados nas fezes. Componentes naturais de alimentos, por serem pretensamente indigestíveis em sua passagem através do trato gastrintestinal, podem ser caracterizados como indicadores internos.

Considerando sua utilidade, ensaios de digestão com eqüinos têm sido realizados avaliando o uso dos indicadores FDAi, CIA e CELi. Há evidências de que é possível a utilização destes compostos para se obter estimativas da digestibilidade de nutrientes, já que os resultados apontam altas taxas de recuperação fecal, bem como similaridade significativa com os coeficientes de digestibilidade de nutrientes calculados a partir do método de colheita total de fezes.

Ponderando a importância da espécie eqüina na pecuária, seu destaque na estrutura sócio-econômica do país nas áreas de esporte e lazer, gerando empregos, capital e divisas de considerável respeito, e, portanto, a necessidade de investir em tecnologia e ciência para melhor criação destes animais, têm-se como objetivos neste trabalho:

avaliar a substituição do rolão de milho (MDPS) pelo farelo de vagem de algaroba (FVA) em rações concentradas para eqüinos através de ensaio de digestibilidade;

analisar a viabilidade econômica de dietas contendo esta fonte alimentar alternativa, e;

comparar os CDMS estimados através de 4 métodos distintos, quais sejam, colheita total de fezes, e três indicadores internos: CELi, FDAi e CIA. 


\subsection{REVISÃO BIBLIOGRÁ FICA}

\subsection{Aspectos gerais sobre a a lgaroba}

Graças aos elevados teores de PB e baixos de parede celular, as leguminosas estão destinadas a ocupar um papel de destaque na alimentação dos herbívoros em geral e, dos ruminantes em particular (GOMIDE e QUEIRÓZ, 1993). Entre as várias espécies estudadas adaptáveis às condições de clima e solo, a algarobeira (Prosopis juliflora (Swartz) D.C.) destaca-se pelo seu valor na produção de frutos, madeira, sombreamento, reflorestamento, suporte à apicultura, e ainda na alimentação humana (FARIAS e BARROS, 1982). Entretanto, a viabilidade desta fonte alternativa de alimentação carece de uma investigação científica, já que o cultivo e a utilização no arraçoamento animal é relativamente recente, sendo até inédito em pesquisas com eqüinos.

A algarobeira é uma leguminosa arbórea que concentra seu valor forrageiro em seus frutos, as vagens (figuras 1 e 2 ). Estas vagens apresentam boa digestibilidade e composição bromatológica adequada, e são constituídas de $58 \%$ de pericarpo, 28,1\% de casca da semente e 13,9\% de sementes (DEL VALLE et al., 1983). Por possuir elevados teores de açúcares totais e sacarose, pode ser usada em rações para bovinos contendo uréia (BARROS e QUEIRÓZ FILHO; 1982; GOMIDE e QUEIRÓZ, 1993).

Devido aos níveis energético e protéico encontrados, a vagem de algaroba é enquadrada na classe dos alimentos energéticos podendo substituir o milho (SILVA et al., 2001). Resultados de análises química e energética, com base na matéria seca, mostram valores variando entre: 8,48 a $14,70 \%$ de $\mathrm{PB}, 9,47$ a $23,12 \%$ de $\mathrm{FB}$, e 3.209 a $4.514 \mathrm{kcal} / \mathrm{kg}$ de EB, sendo ainda rica em sacarose com níveis entre 20 a $30 \%$, somando mais que $50 \%$ dos carboidratos totais, minerais e vitaminas. 
Além das qualidades já citadas, a algarobeira produz vagens durante todo o ano, portanto durante o período de maior escassez de chuva e de alimento, apresentando-se disponíveis para a alimentação animal (AZEVÊDO, 1982). A produção de vagens pode variar de 2 a 8 ton/ha/ano, a depender do modo de extração/cultivo adotado (EMATERBA, 1983).

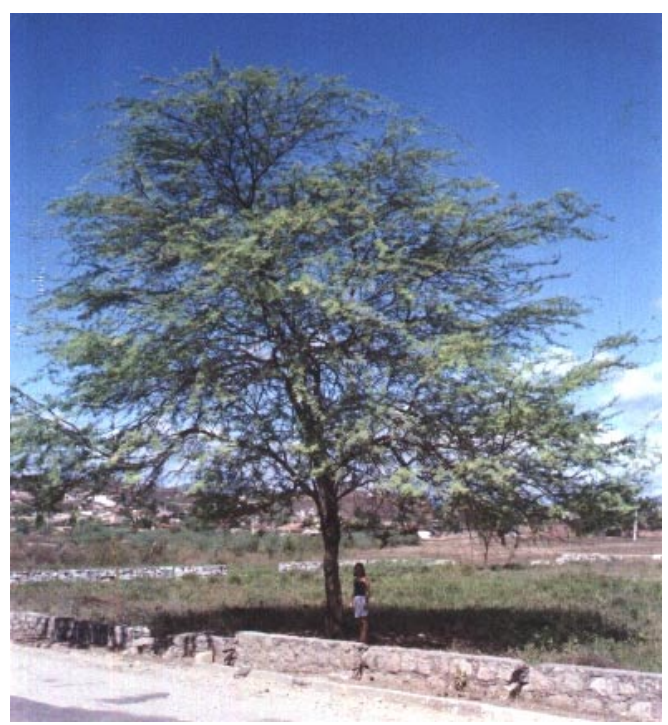

Figura 1: Algarobeira

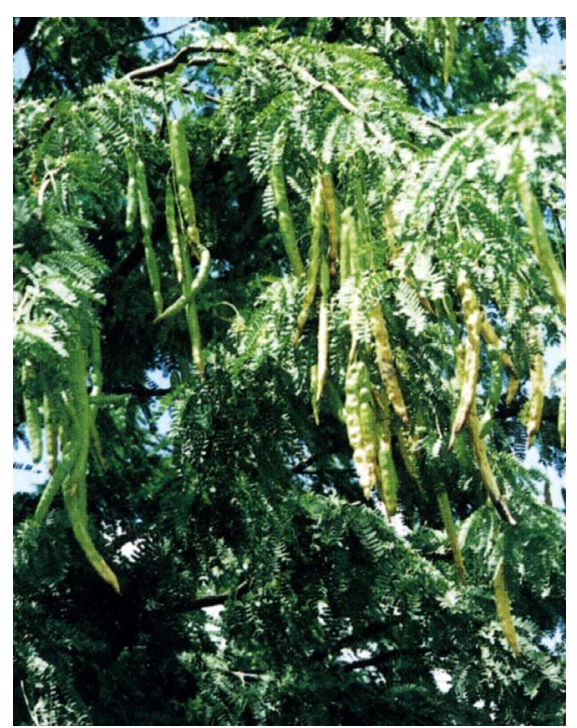

Figura 2: Algaroba: vagens

DEL VALLE et al. (1983) listam razões que mostram o interesse de se estudar o gênero Prosopis; entre elas, seu crescimento e adaptação em solos áridos e semi-áridos, com baixa pluviosidade anual, a riqueza como fonte de proteína e alto conteúdo de lisina. Seu expressivo conteúdo de fibra pode prejudicar o ataque das enzimas digestivas, limitando o acesso das proteases aos locais das células onde as proteínas estão presentes, tendo como conseqüência a redução da digestibilidade deste nutriente. Recomenda-se, pois, seu uso em combinação com cereais para ressaltar os benefícios desta fração nutritiva. Foram encontrados como primeiro e segundo aminoácidos limitantes a treonina e isoleucina, respectivamente. Apesar da riqueza em aminoácidos sulfurosos $(4,7 \mathrm{~g} / 16 \mathrm{~g}$ de $\mathrm{N})$, a metionina representa apenas $28,7 \%$ deste total (semelhante à soja). O fator inibidor de tripsina foi encontrado em níveis insignificantes nas vagens (1,4 TIU - Trypsin Inhibitor Units /mg, na MS) (DEL VALLE et al., 1983).

Não foram encontrados glicosídeos cianogênicos, nem atividade hemaglutinante na farinha de vagens de algaroba processada a $75^{\circ} \mathrm{C}$, porém 
detectou-se a presença de 222,2 TIU/g e 125,40 QIU/g de inibidores de tripsina e quimotripsina, respectivamente (LIMA et al., 1983). Por outro lado, ORTEGANIEBLAS et al., (1996) detectaram alcalóides e atividade hemaglutinante, e obtiveram $60 \mathrm{TIU} / \mathrm{g}$ e 5\% de fenóis na farinha de sementes de algaroba. Apesar disso, os autores comentam que as concentrações são insuficientes para constituírem problemas nutricionais.

No Peru e Havaí, substitui-se o farelo de algodão entre outros concentrados, pelo FVA para ruminantes, aves e suínos. Buo et al., apud AZEVÊDO (1982), refere-se à pesquisa realizada no México com ovinos em engorda, onde a substituição do sorgo pelo FVA em uma ração balanceada permitiu maiores ganhos de peso até o nível de $45 \%$ de substituição, sendo este o tratamento mais econômico.

Estudos realizados no Brasil, utilizando a vagem de algaroba na alimentação de bovinos, ovinos, caprinos, coelhos, aves e suínos, como suplemento energético e/ou protéico, em substituição às fontes de alimentos tradicionais (trigo, milho, sorgo, melaço, etc.), demonstram que há viabilidade no uso das vagens da algarobeira (ARAÚJO et al., 1990; AZEVÊDO, 1982; BARROS e QUEIRÓZ FILHO; 1982; ESPINDOLA et al., 1985; NOBRE, 1982; PINHEIRO et al.; 1986; SILVA, 1990a).

Em relação ao uso da vagem de algaroba na alimentação de eqüídeos, GOMES (1961) relata consumo entre 2 e 6 kg diários, por eqüinos e muares, nas cavalariças do exército Peruano. Segundo MARTIN-ROSSET (1993) o fruto da algarobeira é muito apetecível para os cavalos e estes podem consumir cerca de 1,2 $\mathrm{kg} / 100 \mathrm{~kg}$ de PV/dia. Entretanto o autor comenta que esse material possui digestibilidade limitada.

\subsection{Algaroba: digestibilidad e viabilidade econômica}

A vagem da algaroba tem sido mais intensamente estudada ao longo dos últimos 20 anos, apesar de anteriormente já ocupar um papel relevante na pecuária de regiões de clima semi-árido.

Estudando a viabilidade biológica e econômica da substituição do farelo de trigo pela vagem de algaroba triturada (VAT) em diferentes proporções, na 
alimentação de vacas em lactação, NOBRE (1982) evidenciou maior eficiência de produção de leite e menor custo, quanto maior o nível de substituição, até máximo de $60 \%$. O autor comenta que as diferenças de custo foram devido à variação das quantidades e de preços adotados de outros componentes da ração, já que a algaroba tem amplas condições de contribuir de maneira decisiva e econômica para a melhoria do arraçoamento suplementar dos rebanhos.

SILVA et al. (1982) avaliaram o desempenho de bovinos de corte em confinamento, substituindo em até $100 \%$ do farelo de trigo pela VAT. Não observaram diferenças significativas entre os tratamentos com relação a ganho de peso, porém a dieta contendo $100 \%$ de VAT foi a mais viável economicamente.

BARROS e QUEIRÓZ FILHO (1982) relatam o uso de algaroba em rações para carneiros, à base de farelo de algodão, melaço e uréia, suplementando o capimelefante (Pennisetum purpureum Shum). O uso de 0, 25, 50, 75 e 100\% de vagem de algaroba, em substituição ao melaço, resultou em efeito quadrático sobre o ganho de peso vivo e conversão alimentar, cujos valores máximos ocorreram quando a algaroba substituía, 53,2 e 50,8\%, respectivamente.

TALPADA e SHUKLA (1990) avaliaram vacas em lactação alimentadas com dietas contendo 0,15 e $30 \%$ de VAT. O nível de $15 \%$ de inclusão proporcionou maiores ganhos de peso e maior produção de leite. Os resultados mostraram que a VAT pode ser utilizada até $30 \%$ no concentrado de vacas lactantes, sendo, o custo da alimentação por $\mathrm{kg}$ de leite produzido, reduzido à medida que se aumenta a proporção de algaroba na ração.

Os mesmos autores, TALPADA e SHUKLA (1988), avaliando a digestibilidade e balanços de nutrientes, concluíram que não há diferenças na energia digestível consumida entre os níveis de utilização da VAT. Foi observado um balanço negativo de fósforo, indicando que, em níveis altos (30\%), deve-se suplementar este nutriente para os animais. Ainda neste experimento, foi observada uma tendência de aumento na digestibilidade da $\mathrm{FB}$, sendo os outros coeficientes não significativamente diferentes entre os tratamentos.

RAVIKALA et al. (1995) avaliando dietas completas contendo 0, 15 e 30\% de VAT na alimentação de cordeiros em crescimento, demonstraram não haver diferenças significativas entre os tratamentos, porém a dieta com 15\% de VAT 
resultou em maiores médias de ganho de peso diário, assim como a melhor eficiência alimentar. $\mathrm{O}$ custo de alimentação/kg de ganho foi significativamente $(\mathrm{p}<0,05)$ reduzido na proporção do aumento da algaroba, viabilizando esta fonte alimentar.

Não foram observadas diferenças no consumo (32,5 a 40,2 g MS/kg PV ${ }^{0,75}$ ) e nem entre os CDMS (67,5 a 73,5\%), CDPB (62,4 a 69,9\%) e CDEB (67 a 72\%) quando se ofereceram exclusivamente vagens de algaroba inteiras ou trituradas, aquecidas ou não, para carneiros (BARBOSA, 1977). O autor verifica, contudo, um efeito biológico decrescente entre os tratamentos (trituração e aquecimento). Houve tendência do aquecimento das vagens reduzir o balanço de nitrogênio, mas este não diferiu entre os tratamentos.

No mesmo estudo, BARBOSA (1977) forneceu capim-elefante e vagens de algaroba (inteiras ou trituradas, aquecidas ou não) para carneiros, na proporção 1:1,6 (base na MS). A trituração das vagens proporcionou incremento no consumo de MS, EB e PB, na ED e na proteína digestível (24\% e $25 \%$ a mais, respectivamente). Apesar de não se obterem diferenças entre os tratamentos, observou-se menores coeficientes de digestibilidades nessa mistura comparando-os com o experimento anterior. Estes resultados foram atribuídos à baixa qualidade do capim $(\mathrm{PB}=5,9 \% \mathrm{e}$ conteúdo de parede celular $=68,5 \%)$. Verificou-se efeito inverso ao experimento anterior com respeito à trituração e aquecimento.

Em suínos, estudos avaliaram os efeitos da inclusão de diferentes níveis de algaroba em rações completas sobre desempenho de suínos em terminação. Não foram observados efeitos da inclusão dos níveis na ração sobre os ganhos de peso e consumo médio diário. Entretanto, observou-se efeito linear decrescente significativo sobre a conversão alimentar dos animais (PINHEIRO et al., 1986; PINHEIRO et al., 1993; SILVA et al., 1989b). Atribui-se esse efeito ao aumento dos níveis de fibra das rações, bem como a redução do consumo de metionina, na medida em que se eleva o nível de inclusão de FVA (SILVA et al., 1989a). Contudo, LIMA FILHO et al. (1998) encontraram aumento $(\mathrm{p}<0,05)$ no ganho de peso diário em suínos de 240 a 270 dias de idade, alimentados com diferentes níveis de FVA, e concluíram que este pode ser incluído até $50 \%$ em dietas de suínos machos mestiços, sem nenhum efeito negativo em parâmetros produtivos.

ARAÚJO et al. (1990) não observaram diferenças significativas para 
parâmetros de ganho de peso diário e conversão alimentar na substituição do milho e farelo de trigo pela farinha de vagem de algaroba, até o nível de $30 \%$, na alimentação de suínos em terminação, sendo demonstrada vantagem econômica até o nível de $20 \%$ de inclusão.

Valores de digestibilidade e de metabolismo de animais consumindo dietas a base de VAT ou farinha de pericarpo de algaroba (FPA), foram determinados em coelhos na fase pós-desmame (SILVA et al., 1990a), e em suínos nas fases inicial, crescimento e terminação (SILVA et al.,1989a; SILVA et al.,1989b). Ambos ingredientes substituíram 30\%, com base na MS, das dietas referências. Os valores obtidos em coelhos foram de 2.088 e $3.143 \mathrm{kcal} / \mathrm{kg}$ de ED, de 45,98 e 66,96\% de MS digestível e 71,94 e 76,43\% de digestibilidade da proteína, para VAT e FPA, respectivamente, mostrando a superioridade da FPA. Entretanto, em suínos, as diferenças de digestibilidade e valores energéticos encontrados entre os ingredientes foram explicados em função da perda de sementes no processamento para produzir a FPA, onde se encontraria 35,83 a 39,25\% de proteína e 4,5 a 6,5\% de gordura. Por outro lado, a concentração de inibidores nutricionais nesta porção da vagem podem ter contribuído para a redução dos coeficientes de digestibilidade e energia deste ingrediente observados neste experimento.

ESPÍNDOLA et al. (1985) avaliaram a substituição do milho pela farinha de vagem de algaroba, em rações isoprotéicas para coelhos. Foi constatado aumento significativo no consumo diário bem como piora na conversão alimentar na medida em que se aumentou o nível de algaroba na ração. Os autores concluem que a farinha de vagem de algaroba poderá substituir totalmente o milho, desde que o seu preço por kg não ultrapasse a $65 \%$ do preço por $\mathrm{kg}$ do milho.

Verificando a possibilidade da substituição do milho pela VAT em ração para frangos de corte, ASSIS et al. (1990) recomendou a substituição de até 15\% do milho, a depender de uma análise econômica, enquanto BRANDÃO et al. (1989) recomendou a utilização de até 5\%, nas rações inicial e final, sem afetar significativamente o desempenho dos animais. Resultados sugerem que até $10 \%$ de vagem de algaroba pode ser incorporado em dietas iniciais e finais de frangos sem nenhum efeito adverso sobre o desempenho (VANKER et al., 1998).

PINHEIRO et al. (1998) verificaram efeito cúbico para consumo alimentar 
em frangos de corte. Os autores alegam que características organolépticas inerentes à farinha de vagem de algaroba tenham influenciado negativamente o consumo, na mesma proporção de seu aumento na ração. Os efeitos lineares decrescente para ganho de peso e crescente para a conversão alimentar, são explicados pelo aumento de fibra na ração, o que reduziria a digestibilidade dos demais nutrientes, e ainda pela presença de fatores antinutricionais (tanino e inibidor de tripsina). Pelo estudo econômico, recomendou-se até o nível de 7\% de substituição.

Testando níveis de inclusão ( 0 a $25 \%$ ) de FVA na ração de codornas japonesas, OLIVEIRA et al. (2001c) observaram resposta quadrática obtendo nível ótimo de inclusão de $15,66 \%$ para o consumo de ração, quando excluiu o tratamento com $0 \%$ de FVA. Na produção e massa de ovos as melhores respostas foram obtidas com níveis de 14,91 e 14,81\%, respectivamente. Segundo os autores, o aumento de fibra da ração deve ser a principal explicação para a queda de desempenho das codornas no nível de $25 \%$ de inclusão da FVA.

\subsection{Digestibilidade em eqüin os}

Classificados como herbívoros com ceco e cólon funcional, os eqüinos têm necessidade de uma dieta balanceada que contenha níveis adequados de nutrientes, além de fibra e energia, para executar suas funções. Como ruminantes, possuem câmaras fermentativas, ceco e cólon, nas quais ocorre a degradação do alimento que escapou da digestão química no intestino delgado.

Os eqüinos utilizam como fonte primária de energia os carboidratos, que primeiro são expostos às enzimas pancreáticas e intestinais antes de chegarem às câmaras de fermentação (NRC, 1989). O intestino delgado é responsável por $80 \mathrm{a}$ 95\% da digestão dos açúcares e amido, e 80\% do desaparecimento da proteína dietética e das gorduras.

Segundo MEYER (1995), a atividade do ceco e do cólon depende principalmente do tipo e da quantidade de substâncias nutritivas provenientes do intestino delgado, da velocidade de trânsito e da capacidade de tamponamento no lúmen. Do tempo total de trânsito, cerca de $85 \%$ são gastos no intestino grosso. FRAPE (1986) relata que o conteúdo digestivo é movimentado $30 \mathrm{~cm}$ por minuto, 
sendo que a maioria deste alcançará o ceco 3 horas após a refeição fornecida.

A celulose em combinação com outros componentes vegetais é considerada a base do alimento volumoso para eqüinos. O principal produto da fermentação dos carboidratos estruturais presentes nestes alimentos, tal como em ruminantes, são os $\mathrm{AGV}$, que servem como fontes de energia assim que são absorvidos pela parede do intestino grosso nos eqüinos, ou pelas paredes do rúmem em ruminantes. De acordo com o NRC (1989), uma larga fração da energia metabolizável é derivada desses compostos, sendo o proprionato o principal precursor de glicose.

Quando grandes quantidades de concentrado chegam ao intestino grosso, a proporção entre estes ácidos se modifica, podendo ocorrer redução do $\mathrm{pH}$. As conseqüências desta fermentação excessiva seriam o desequilíbrio da flora e fauna, formação de gases e ácidos indesejáveis, associados a uma digestão de alimento irregular (MEYER, 1995).

De acordo com MEYER (1995) o mínimo de FB na dieta total (em MS) deve estar entre 16 a 18\% para animais que se encontram em manutenção (mínimo de 0,5 $\mathrm{kg} / 100 \mathrm{~kg} \mathrm{PV} /$ dia). O autor cita algumas conseqüências da ingestão ineficiente deste material: 1) aumento dos riscos para vários tipos de distúrbios; 2) formação de pontas nos dentes molares por uma mastigação incompleta; 3) a quantidade reduzida de saliva pode ocasionar obstrução do esôfago ou fermentações excessivas no estômago; 4) a ocupação e saciedade insuficiente podem levar a vícios ou a ingestão aumentada de cama. A menor atividade de síntese dos microorganismos intestinais na dieta pobre em fibras favorece o aparecimento de deficiências nutricionais latentes. O limite superior na ingestão de volumoso é dado pela necessidade em energia e pela capacidade de ingestão de alimento.

Em herbívoros, fatores determinantes da extensão da utilização de fibras no sistema digestivo, são o tempo disponível e a eficiência microbiana da digestão (De FOMBELLE et al., 1999). Neste aspecto encontramos uma das principais diferenças entre a digestão das fibras em eqüinos e ruminantes. Resultados de dois experimentos mostraram que a alimentação com altas porcentagens de grãos, mesmo com aumento do tempo de digestão, deprime a eficiência da utilização da fibra (menores digestibilidades aparente de FDA e FDN) no ecossistema microbiano em pôneis, provavelmente devido a uma sobrecarga no intestino delgado pelo concentrado, 
alcançando este o ceco e cólon, sendo mais evidente quando o concentrado foi servido primeiro (De FOMBELLE et al., 1999).

A constituição e forma física da dieta influenciam a taxa de passagem do conteúdo digestivo e, conseqüentemente, a digestão de nutrientes. Resultados de experimentos com alfafa mostraram menor digestão de FDA em peletes comparados ao feno de alfafa. Contudo não houve diferença na digestão de MS (CYMBALUK, 1990). Estes resultados são atribuídos ao menor tempo de retenção dos peletes em relação às fibras longas ou picadas apenas.

O NRC (1989) preconiza o processamento de dietas e alimentos fornecidos para cavalos, com a finalidade de elevar a digestibilidade destes materiais. Contudo, alerta para a necessidade de conter fibras longas na dieta. A trituração demasiada pode ocasionar distúrbios justamente pelo fato de reduzir o tempo de retenção destas partículas, além de fermentarem muito rapidamente.

Segundo FRAPE (1986), cavalos têm menor capacidade de digerir fibras quando comparados aos ruminantes domésticos. Logo, gramíneas antes do florescimento, contendo uma proporção maior de folhas se torna um alimento valioso. O fator mais importante relatado pelo NRC (1989) em relação à qualidade da forragem é o estágio de maturidade no tempo de colheita, estando este relacionado com a quantidade e qualidade da fibra existente neste material.

Ao comparar a digestão de fenos em bovinos e eqüinos, CYMBALUK (1990) registrou maiores coeficientes de digestibilidade da MS, EB, FDA e FDN para bovinos sendo a digestibilidade da proteína similar entre as espécies. Ao comparar os resultados com um segundo experimento, concluiu que eqüinos digerem melhor a MS de feno de leguminosas do que de gramíneas; mas isto pode depender da maturidade a qual a planta é colhida e, portanto, do conteúdo de fibras.

Um fator considerado importante para a digestibilidade das fibras é o teor de lignina da forragem, que ao elevar-se, provoca redução na digestibilidade do alimento. $\mathrm{O}$ conteúdo em FB de sementes de leguminosas é mais alto em relação ao dos cereais ( 6 a 14\%), porém sua digestibilidade é maior devido ao baixo teor em lignina, principalmente se há um processamento ou uma moagem grosseira prévia (MEYER, 1995).

LaCASHA et al. (1999) encontraram digestibilidade do feno de Coast cross 
(Cynodon dactylon cv. Coast Cross) inferior ao feno de alfafa, excetuando-se, contudo, os componentes da parede celular. Relacionou-se este fato ao reduzido conteúdo total destes componentes presentes no feno de alfafa, o que redundaria em maior taxa de passagem, portanto, ocasionando menor tempo de fermentação.

Observou-se aumento na digestibilidade dos constituintes de parede celular em função da redução no teor de FDN das dietas. O menor consumo deste nutriente pode reduzir a taxa de passagem, elevando, conseqüentemente, o tempo de retenção do conteúdo digestivo no ceco e cólon e favorecendo a fermentação da fibra no intestino grosso (OLIVEIRA, 1995).

A menor capacidade de digestão de fenos fibrosos, se deve ao número e atividade celulolítica da microflora cecal, sendo estes menores em relação aos bovinos (CYMBALUK, 1990; FRAPE, 1986). A digestibilidade da MO e da FB em cavalos alimentados com dietas contendo mais que 15\% de FB estão cerca de 85 e 70-75\%, respectivamente, dos valores estimados para ruminantes (FRAPE, 1986). Isto é atribuído, novamente, a maior taxa de passagem característica nesta espécie, além das diferenças entre as espécies bacterianas celolulíticas.

PEARSON e MERRITT (1991) estimaram a digestibilidade aparente em pôneis alimentados com feno versus palha de cevada. A palha proporcionou menores coeficientes de digestibilidade para a MS, MO e EB, entretanto a digestibilidade da FDA e FDN foram maiores. Esses resultados foram atribuídos ao maior tempo de retenção do conteúdo digestivo proporcionado pela palha em relação ao feno, permitindo uma fermentação mais extensiva deste material nas câmaras. Os mesmos autores compararam o tempo de retenção do conteúdo digestivo estimado por marcadores (Cr mordente e Co-EDTA) e relataram que existe aparentemente menor retenção seletiva de partículas sólidas no trato posterior dos eqüinos do que no estômago compartimentado dos ruminantes.

Os eqüinos utilizam a energia de carboidratos solúveis mais eficientemente que os bovinos pelo fato de absorverem mais, proporcionalmente, na forma de açúcares. O nitrogênio também é menos aproveitado, já que a proteína dietética é em menor proporção convertida para proteína microbiana (FRAPE, 1986). Não se pode esquecer, entretanto, que, por este mesmo fato, há necessidade de fornecimento dos aminoácidos essenciais dieteticamente, com especial atenção para a lisina, primeiro 
aminoácido limitante para cavalos. Mesmo ocorrendo a produção de proteína microbiana no intestino grosso, a literatura em geral concorda que apenas uma pequena porção desta produção está disponível para o cavalo.

Quanto maior a porção do alimento degradado e absorvido antes do intestino grosso, maior é o rendimento da energia digestível, e menores os riscos de processos fermentativos indesejáveis (MEYER, 1995). A retenção estomacal do alimento rico em proteínas e carboidratos solúveis melhora a utilização desses nutrientes nas primeiras porções do trato gastrointestinal (GONÇALVES et al., 1998). A administração conjunta de volumoso e concentrado não diminuem a digestibilidade dos componentes do concentrado, bem como altas percentagens de amido não influenciam a digestibilidade da FB. A presença do amido eleva a taxa de degradação no intestino grosso (FRAPE, 1995).

REZENDE et al. (1998), avaliando diferentes ordens de alimentação de uma dieta constituída de feno Coast cross e concentrado na proporção de 1:1, demonstraram que o fornecimento dos dois alimentos simultaneamente ou do volumoso 3 horas antes do concentrado proporcionam maiores coeficientes de digestibilidade das frações fibrosas em comparação ao fornecimento do concentrado 3 horas antes do feno. A explicação provável seria a chegada mais rápida do volumoso ao intestino grosso permanecendo lá mais tempo e conseqüentemente sob melhor atuação das bactérias.

Segundo ARAÚJO et al. (1997) diferentes formas de arraçoamento com dietas mistas não interferem na digestibilidade de nutrientes, considerando o fornecimento de grãos 2 ou 4 horas após volumoso ou fornecimento de grãos em única refeição junto com $1 / 3$ de volumoso.

O fornecimento de dietas mistas é preferencial às dietas de volumoso exclusivo. A melhoria na digestibilidade é provavelmente devido ao aumento da taxa de passagem do concentrado pelo intestino delgado ocasionado pelo volumoso, servindo este de substrato para a flora, favorecendo a digestão e produção de energia $(\mathrm{AGV})$ a partir dos carboidratos estruturais do alimento fibroso.

ALVARENGA (1996) relatou para uma dieta de feno de Coast cross exclusivo coeficientes de digestibilidade aparente médios inferiores na ordem de 26,0, 18,7, 29,6 e 13,2\% para MS, MO, PB e FDN, respectivamente, comparados a 
dieta mista composta de $70 \%$ feno e $30 \%$ concentrado. Segundo o autor, o fato do animal consumir preferencialmente o concentrado promove preenchimento gástrico rápido na região pilórica e, portanto, pouca alteração no $\mathrm{pH}$, permitindo alta atividade microbiana no estômago e duodeno. A conseqüência deste processo seria uma rápida digestão do concentrado e mais eficiente do volumoso que vem sendo ingerido na seqüência.

Comparando a utilização de energia e a digestibilidade entre pôneis e cavalos VERMOREL et al. (1997) observaram melhores CD na dieta contendo milho (30\%), em relação ao fornecimento exclusivo de feno e suplemento mineral. Em relação às perdas de energia, a dieta mista também se mostrou mais eficiente.

OLIVEIRA et al. (2001a) avaliaram a digestibilidade aparente em eqüinos, com 12 a 18 meses de idade, alimentados com diferentes proporções de concentrado e volumoso (Coast cross). Foi observado efeito linear negativo no coeficiente de digestibilidade da MS em função dos níveis de fibra nas dietas enquanto nos coeficientes de digestibilidade da $\mathrm{PB}$ e EB foi observado efeito quadrático com pontos máximos de 76,9\% (CDPB) e 66,12\% (CDEB). Não se verificou influencia sobre os CDFDA e CDFDN nem sobre o consumo.

De acordo com ALMEIDA et al. (1998b) existe uma maior eficiência de digestão microbiana no intestino grosso quando o aporte de substrato é qualitativamente maior em proteína não-digerida no intestino delgado (local primário para degradação deste nutriente), quando este alcança seu limite máximo de digestão. A digestibilidade aparente total da PB neste mesmo trabalho, com potros, apresentou comportamento quadrático, em função do teor de PB elevado na dieta estimando-se o máximo em 79,98\% para o nível de $17,92 \%$ de PB ingerida. A média de digestibilidade aparente total da MS foi $64,0 \%$.

Elevando o teor protéico através do farelo de soja na alimentação de potros, ALMEIDA et al. (1998c) encontraram maiores digestibilidades de compostos nitrogenados, o que indicaria que o excesso desses compostos que passam do íleo ao intestino grosso é digerido neste local. As médias de digestibilidade aparente total da MS estiveram entre 67,36 e 69,69\%.

$\mathrm{Na}$ tabela 1 estão catalogados valores de coeficientes de digestibilidade aparente em eqüinos de diversos nutrientes em dietas à base de feno e concentrado. A 
literatura mostra uma variação de informações, dependendo principalmente do tipo e idade da forragem avaliada.

Tabela 1: Valores de coeficientes de digestibilidade aparente total publicados: autor (es), ano de publicação, dieta utilizada e categoria animal.

\begin{tabular}{|c|c|c|c|c|c|c|c|}
\hline \multirow{2}{*}{ Bibliografia } & \multicolumn{7}{|c|}{ Coeficientes de digestibilidades dos nutrientes (\%) } \\
\hline & $M S$ & MO & $F D N$ & $F D A$ & HCEL & $P B$ & $E B$ \\
\hline $\begin{array}{c}\text { ALVARENGA, } 1996^{1,2} \\
\text { Feno Coast cross: concentrado, } \\
70: 30 \%\end{array}$ & 59,15 & 62,60 & 56,20 & & & 70,50 & \\
\hline $\begin{array}{l}\text { ARAÚJO et al., } 1997^{1,2} \\
\text { Feno Coast cross:concentrado, } \\
50: 50 \%\end{array}$ & 63,75 & & 52,04 & 39,94 & 62,59 & 67,28 & 63,93 \\
\hline $\begin{array}{c}\text { ARAÚJO, } 1999^{2} \\
\text { Feno Coast cross:milho }\end{array}$ & 60,71 & 61,51 & 48,54 & 39,09 & 56,90 & 56,51 & 57,14 \\
\hline $\begin{array}{c}\text { Feno Coast cross:farelo de soja, } \\
60: 40 \%\end{array}$ & 57,62 & 58,17 & 44,49 & 39,87 & 49,57 & 85,18 & 59,38 \\
\hline $\begin{array}{c}\text { De FOMBELLE et al., } 1999 \\
\text { Feno (picado): concentrado, } 70: 30\end{array}$ & & 55,00 & 40,40 & 36,10 & & & \\
\hline $\begin{array}{l}\text { e 50:50\%, } \\
\text { respectivamente, em pôneis }\end{array}$ & & 63,70 & 39,30 & 33,90 & & & \\
\hline $\begin{array}{l}\text { GONÇALVES et al., } 1998^{2,3} \\
\text { Feno Coast cross: concentrado, } \\
50: 50 \%\end{array}$ & 54,05 & & & & & 57,35 & 54,40 \\
\hline $\begin{array}{l}\text { MARTIN-ROSSET et al., } 1990 \\
\text { Feno:concentrado, } 85: 15 \%{ }^{1,2}\end{array}$ & 52,90 & 54,00 & & & & 57,90 & 49,80 \\
\hline $\begin{array}{c}\text { MIRAGLIA et al., } 1999^{2} \\
2 \text { dietas com a mesma mistura de }\end{array}$ & 58,28 & 61,78 & 46,64 & 40,82 & & 65,24 & 61,67 \\
\hline $\begin{array}{c}\text { concentrados peletizados } \\
67: 33 \% \\
\end{array}$ & 61,69 & 64,38 & 52,56 & 46,33 & & 68,85 & 64,27 \\
\hline $\begin{array}{l}\text { OLIVEIRA et al., } 2001 \mathrm{a} \\
\text { Feno Coast cross:concentrado, } \\
60: 40 \% \text {, animais de } 12 \text { a } 18 \text { anos }\end{array}$ & 61,95 & & 50,60 & 41,61 & & 74,85 & 62,55 \\
\hline $\begin{array}{c}\text { OLIVEIRA et al., } 2001 \mathrm{~b}^{2} \\
\text { Feno Coast cross:farelo de soja } \\
86,5: 13,5 \% \text {. }\end{array}$ & 49,58 & & 52,61 & 49,82 & 55,50 & 63,85 & 48,61 \\
\hline $\begin{array}{c}\text { REZENDE et al., } 1998^{2,3} \\
\text { Feno Coast cross:concentrado } \\
50: 50 \%\end{array}$ & & & 42,25 & 24,65 & 57,20 & & \\
\hline $\begin{array}{c}\text { VERMOREL } \text { et al., } 1997^{2} \\
\text { Feno:milho peletizado } \\
70: 30 \%\end{array}$ & 63,20 & & 51,90 & 47,60 & & 61,30 & 60,70 \\
\hline
\end{tabular}

${ }^{1}$ Média de tratamentos.

${ }^{2}$ Animais adultos.

${ }^{3}$ Média obtida de tratamentos. A: concentrado fornecido junto ao feno e C: concentrado fornecido 3 horas após o feno. 


\subsection{Consumo}

A energia requerida para a manutenção do cavalo é destinada a manter a temperatura corpórea e as funções elementares, ou seja, metabolismo basal, além da ingestão de alimentos e sua digestão e movimentos não direcionados, ainda assim vitais (MEYER, 1995). Os gastos adicionais em parte estão numa relação linear com o PV. A necessidade diária de energia digestível é por sua vez relacionada ao PV com o expoente $0,75\left(\mathrm{PV}^{0,75}\right)$, a qual se denomina peso metabólico.

O consumo esperado para animais em manutenção corporal varia em torno de 2\% do PV, em MS (FRAPE, 1986; MEYER, 1995; NRC, 1989). Deste valor, ao menos $1 \%$ deve ser fornecido na forma de forragem de boa qualidade. Segundo o NRC (1989), animais nesta categoria são capazes de consumir até 2,5\% do PV em MS de dieta exclusiva de volumoso, preenchendo seus requerimentos completamente.

A digestibilidade de diferentes forragens conservadas foi medida em pôneis (MOORE-COLYER e LONGLAND, 2000). Dos alimentos testados, o feno foi o que apresentou menores valores. O consumo de energia e proteína digestíveis calculados excedeu os requerimentos diários dos pôneis com as forragens, com exceção do feno (consumo de proteína digestível apenas $20 \%$ do requerido), o que resultou em deficiências destes nutrientes. O consumo de MS diário médio de feno foi de 1,49\% $\mathrm{PV}, 4,95 \mathrm{~kg} \mathrm{MS} /$ dia ou $62,9 \mathrm{~g} \mathrm{MS} / \mathrm{kg} \mathrm{PV}^{0,75}$.

Sob a perspectiva do peso metabólico corporal, para alcançar os requerimentos energéticos, eqüinos devem consumir mais forragem de baixa qualidade por unidade de peso metabólico, para compensar sua reduzida habilidade de utilizar energia destes volumosos, em relação aos bovinos. CYMBALUK (1990) observou que o consumo de MS e FDN entre bovinos e eqüinos foi similar. Conhecendo-se a relação inversa existente entre o consumo de MS e o teor de FDN na forragem, e sendo esta finita devido ao limite de enchimento do intestino delgado, CYMBALUK (1990) relata a semelhança entre estas espécies em suas limitações do intestino delgado apesar das diferenças no tempo de retenção e taxa de passagem.

Foram observados maiores consumos de MS quando se reduziu o nível de fibra da dieta em potros com 20 meses de idade (OLIVEIRA, 1995). Com a adição 
de milho triturado e farelo de soja, reduziu-se o nível de fibra da ração elevando conseqüentemente o consumo de MS (4,1, 4,8 e 5,7 kg MS/dia para dietas a) capim elefante exclusivo, b) capim + milho e $c$ ) capim + milho e soja, respectivamente, com proporção volumoso:concentrado 1:1).

Discordando destes resultados, OLIVEIRA et al. (2001a) não observou diferenças de consumo em potros com idade de 12 a 18 meses, alimentados com diferentes proporções de concentrado e volumoso (médias de consumo $=2 \% \mathrm{PV}$,

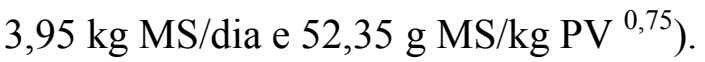

VERMOREL et al. (1997) compararam a utilização de energia e a digestibilidade entre pôneis e cavalos fornecendo duas dietas: feno exclusivo ou feno + milho peletizado. As médias de consumo de MS foram 55,7 e 76,7 g MS/kg PV ${ }^{0,75}$ na dieta exclusiva com feno e 38,6 e $58,2 \mathrm{~g} \mathrm{MS} / \mathrm{kg} \mathrm{PV}^{0,75}$ na dieta com concentrado para pôneis e cavalos, respectivamente.

Segundo MEYER (1995), cavalos em manutenção necessitam de cerca de $3 \mathrm{~g}$ de proteína digestível por $\mathrm{kg} \mathrm{PV}{ }^{0,75}$, sendo estas suficientes para manter o equilíbrio em nitrogênio do organismo e ainda permitir um discreto acúmulo de proteína.

De acordo com o NRC (1989) a proteína compõe cerca de $80 \%$ da estrutura corporal (livre de gordura e água) de um cavalo. Seu requerimento varia em função da necessidade animal, da qualidade e disponibilidade da proteína, e da sua digestibilidade, sendo que animais em crescimento são mais sensíveis à qualidade do que os que estão apenas em manutenção.

A digestibilidade da proteína de uma dieta varia entre 43 e 69\%. Uma relação concentrado:volumoso maior que 1:1 pode resultar em maiores digestibilidades (70 a 75\%). A recomendação para mantença é de $1,3 \mathrm{~g}$ de $\mathrm{PB} / \mathrm{kg}$ de $\mathrm{PV} /$ dia, considerando dietas de volumosos de baixa qualidade, com CD da PB de 46\% (NRC, 1989).

ALMEIDA et al. (1998b) trabalhando com 5 diferentes níveis de proteína em dieta $50 \%$ feno Coast cross e $50 \%$ concentrado (milho e soja), observaram aumento de consumo de MS até o nível de 14,55\% de PB (2,32\% a 2,57\% PV), conforme equação estabelecida. Mais tarde registraram consumos de MS (1,87 a 2,30\% PV ou

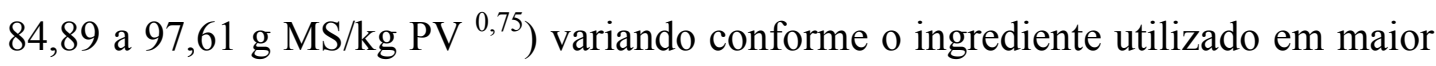
proporção no concentrado (60\% de milho ou soja) (ALMEIDA et al., 1998c). Os resultados foram associados aos níveis de proteína, carboidratos solúveis e amido 
presente nas diferentes dietas.

Dietas mistas de feno e milho ou feno e soja (60:40\%) proporcionaram consumos de 1,96 e 2,11\% PV (ARAÚJO, 1999).

O consumo de até 1,6 vezes o nível de mantença de dieta contendo $85 \%$ de feno e $15 \%$ de concentrado não afetou a digestibilidade de nutrientes em éguas com peso médio de $510 \mathrm{~kg}$ (MARTIN-ROSSET et al., 1990).

\subsection{Estimativa de digestibilidade através de indicadores internos}

Estudos com indicadores internos e externos têm sido utilizados em ensaios de digestibilidade em eqüinos com o objetivo de tornar as estimativas de digestibilidade aparente de nutrientes mais práticas, econômicas e menos laboriosas. A CIA, a FDAi e a CELi são alguns desses indicadores que tem apresentado estimativas próximas às da colheita total e portanto vistos como indicadores potenciais.

Estudando a CIA, MACHADO (1992) concluiu que o indicador foi eficiente em estimar a digestibilidade de nutrientes em eqüinos, com coeficientes semelhantes àqueles obtidos com a coleta total de fezes e, apresentando porcentagens de recuperação próximas de 100\%. ARAÚJO (1999) chegou a este mesmo resultado quando forneceu $60 \%$ de feno Coast cross e $40 \%$ de milho ou farelo de soja para eqüinos. Ambos autores ressaltam, todavia, a necessidade de mais estudos nesta espécie, a fim de avaliar com segurança o potencial deste indicador.

MIRAGLIA et al. (1999), utilizando duas dietas constituídas de feno e dois diferentes concentrados, ambos peletizados, nas proporções de 67:33, obtiveram estimativas de coeficientes de digestibilidade pela CIA ligeiramente superiores aos obtidos pela colheita total de fezes, não diferindo, contudo, estatisticamente. Foram calculadas correlações entre os dois métodos, observando-se valores de $85 \%$ para MS, de $83 \%$ para $\mathrm{MO}$, de $81 \%$ para energia, de $90 \%$ para $\mathrm{FB}$, de $89 \%$ para $\mathrm{PB}$, de $84 \%$ para FDA, de $90 \%$ para FDN, de $85 \%$ para extrato nitrogenado livre, de $98 \%$ para extrato etéreo. Os autores ressaltam que as diferenças obtidas entre o CDMS observados na literatura são provavelmente devido à variação de alimentos utilizados, já que nos seus próprios experimentos, diferentes concentrados deram 
origem a diferentes coeficientes de digestibilidade.

Estimativas da digestibilidade através da CIA em $\mathrm{HCl}$ a $2 \mathrm{~N}$ apresentaram porcentagens de recuperação fecal bastante próximas de 100\% $(100,12 \pm 1,51$ e $101,32 \pm 1,20$, para dieta de feno exclusivo de Coast cross e feno + capim elefante 60:40\%, respectivamente). Os valores de digestibilidade dos nutrientes MS, MO, PB, EB, FDN, FDA e HCEL das duas dietas foram semelhantes ao método de colheita total de fezes (ARAÚJO et al., 2000).

Colheitas de fezes efetuadas em diferentes horários (as 10 e 16 horas) não mostraram diferenças para os teores de CIA. Mediram-se ainda as concentrações de CIA nas fezes durante períodos de $24 \mathrm{~h}$, sendo estas razoavelmente constantes, confirmando, portanto, os resultados das colheitas parciais realizadas (CUDDEFORD e HUGUES, 1990). Os autores concluem que a CIA pode ser utilizada como marcador indireto para estimar coeficientes de digestibilidade de nutrientes em cavalos, quando a colheita total de fezes é impraticável.

PENNING e JOHNSON (1983a) utilizaram como marcadores a CIA e a CELi em ovinos para estimar a digestibilidade aparente da MO, e recomendaram a utilização da CELi. O tempo de incubação in vitro requerido para digerir as amostras foi determinado: 6 dias seriam suficientes para a digestão completa das amostras de alimento, enquanto para fezes, 10 dias de incubação seriam necessários. Das forragens utilizadas (Lolium perenne cv. Melle e Medicago sativa cv. Maris Phoenix), relatou-se pior estimativa da CIA para a alfafa. Uma menor taxa de passagem desta forragem poderia incorrer na necessidade de maior tempo para este marcador alcançar um equilíbrio no trato gastro intestinal.

Os mesmos autores, em um segundo trabalho equivalente, concluíram que a FDAi pode ser usada como um indicador confiável para predizer a digestibilidade da MO em ovinos. O FDAi alcançou um valor constante após 5,5 dias de incubação (PENNING e JOHNSON, 1983b).

SUNVOLD e COCHRAN (1991) compararam os marcadores CIA e FDAi, entre outros, com a colheita total de fezes em bovinos para predição da digestibilidade da MO de diferentes tipos de forragem. As estimativas da FDAi foram diferentes da colheita total. Contudo, para a CIA, não houve diferença significativa com relação à estimativa de digestibilidade aparente da MO para os 
fenos de gramíneas. Com relação ao feno de alfafa, observou-se uma superestimativa associada a uma taxa de recuperação maior que 100\%. A recomendação existente na literatura é que a ração ou alimento contenha no mínimo 0,75\% de CIA (na MS) para que esta estime a digestibilidade, em ruminantes, com precisão. Relatou-se neste trabalho apenas $0,3 \%$ de CIA no feno de alfafa, o que explicaria este resultado.

ALMEIDA et al. (2000), não encontraram diferenças entre os coeficientes de digestibilidade da MS obtidos com a FDAi e CELi comparados à colheita total de fezes, com o percentual de recuperação fecal destes indicadores de 98,75 e 101,72\%, respectivamente.

FERRET et al. (1999) trabalharam com FDAi comparando-o, entre outros indicadores, com a colheita total de fezes, em ovinos. Devido a taxa de recuperação encontrada diferente de $100 \%$ em 4 das 8 dietas estudadas (média $=92,1 \%$ ), os autores não recomendam sua utilização como indicador. Relataram ainda o efeito do tipo de feno afetando a taxa de recuperação dos indicadores.

Os resultados de estimativas da digestibilidade aparente pré-cecal da MS em eqüinos utilizando FDAi e CELi como indicadores são contraditórios. ALMEIDA et al. (1998a) relatam uma super estimativa do fluxo de MS ileal, resultando em valores negativos de digestibilidade; entretanto os autores atentam para o fato da recuperação destes materiais fibrosos ter sido prejudicada pela possível retenção nas cânulas.

ALVARENGA (1996), avaliando 5 indicadores internos, concluiu que a FDAi foi o que melhor estimou o fluxo de conteúdo digestivo ileal em eqüinos consumindo $70 \%$ de feno de capim Coast cross e $30 \%$ de concentrado. A metodologia utilizada para obter o FDAi, neste caso, foi a digestibilidade in situ. O mesmo autor observou menores taxas de recuperação (FDAi) na dieta mista em comparação ao feno exclusivo (86,6 e 96,1\% versus 72,9 e $80 \%)$. 


\subsection{MATERIAL E MÉTODOS}

\subsection{Local}

O experimento foi conduzido nas dependências do Setor de Eqüinocultura do Instituto de Zootecnia da Universidade Federal Rural do Rio de Janeiro (UFRRJ), Rodovia BR 465, km 47, Seropédica - RJ. De acordo com a estação experimental de Itaguaí-RJ, as coordenadas do local de experimento são: $22^{\circ} 45^{\prime} \mathrm{S}$ e $43^{\circ} 41^{\prime} \mathrm{W}$ e altitude $33 \mathrm{~m}$. Os dados meteorológicos colhidos no período $1^{\circ}$ a 30 de junho de 2001 registram temperaturas máxima, mínima e média, respectivamente, de $26,8^{\circ} \mathrm{C}$, $16,8^{\circ} \mathrm{C}$ e $21,0^{\circ} \mathrm{C}$, umidade relativa de $68,7 \%$ e precipitação de $15,3 \mathrm{~mm}$.

As análises foram efetuadas nos Laboratórios de Bromatologia e das Agrárias do Departamento de Zootecnia da Faculdade de Zootecnia e Engenharia de Alimentos da Universidade de São Paulo (FZEA - USP).

\subsection{Animais}

Foram utilizadas 16 éguas da raça Mangalarga Marchador, com idade entre 3,5 e 18,4 anos e peso médio de 394,8 $\pm 42,66 \mathrm{~kg}$ (figuras 3 e 4).

\subsection{Instalações}

Foram utilizadas baias individuais com dimensões de $3,5 \mathrm{~m} \mathrm{x} \mathrm{3,0} \mathrm{m,} \mathrm{providas}$ de piso de cimento, sem cama, comedouros para ração, volumoso, sal e bebedouro tipo balde. 


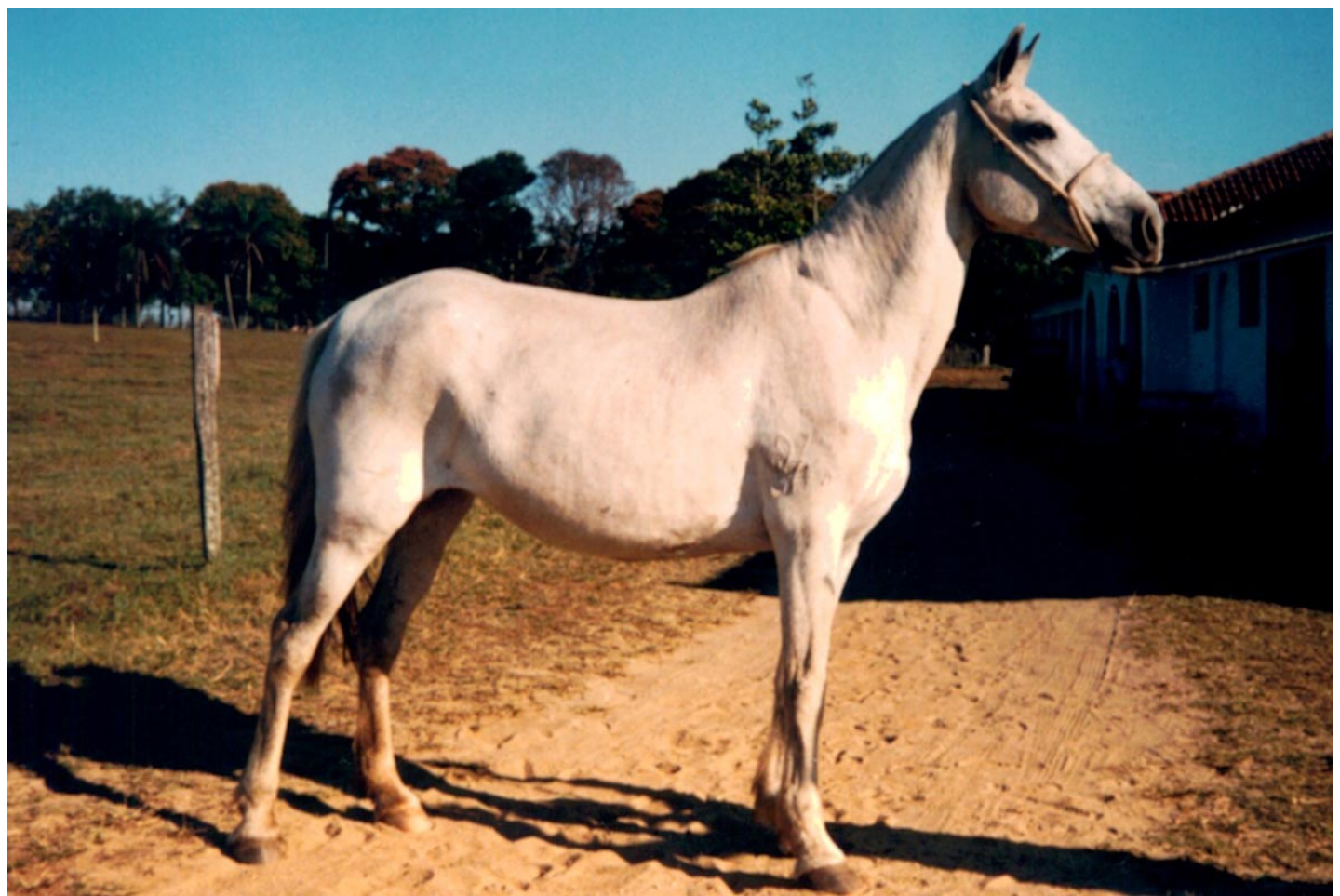

Figura 3: Égua Mangalarga Marchador - Quarela, 18 anos, Bloco IV.

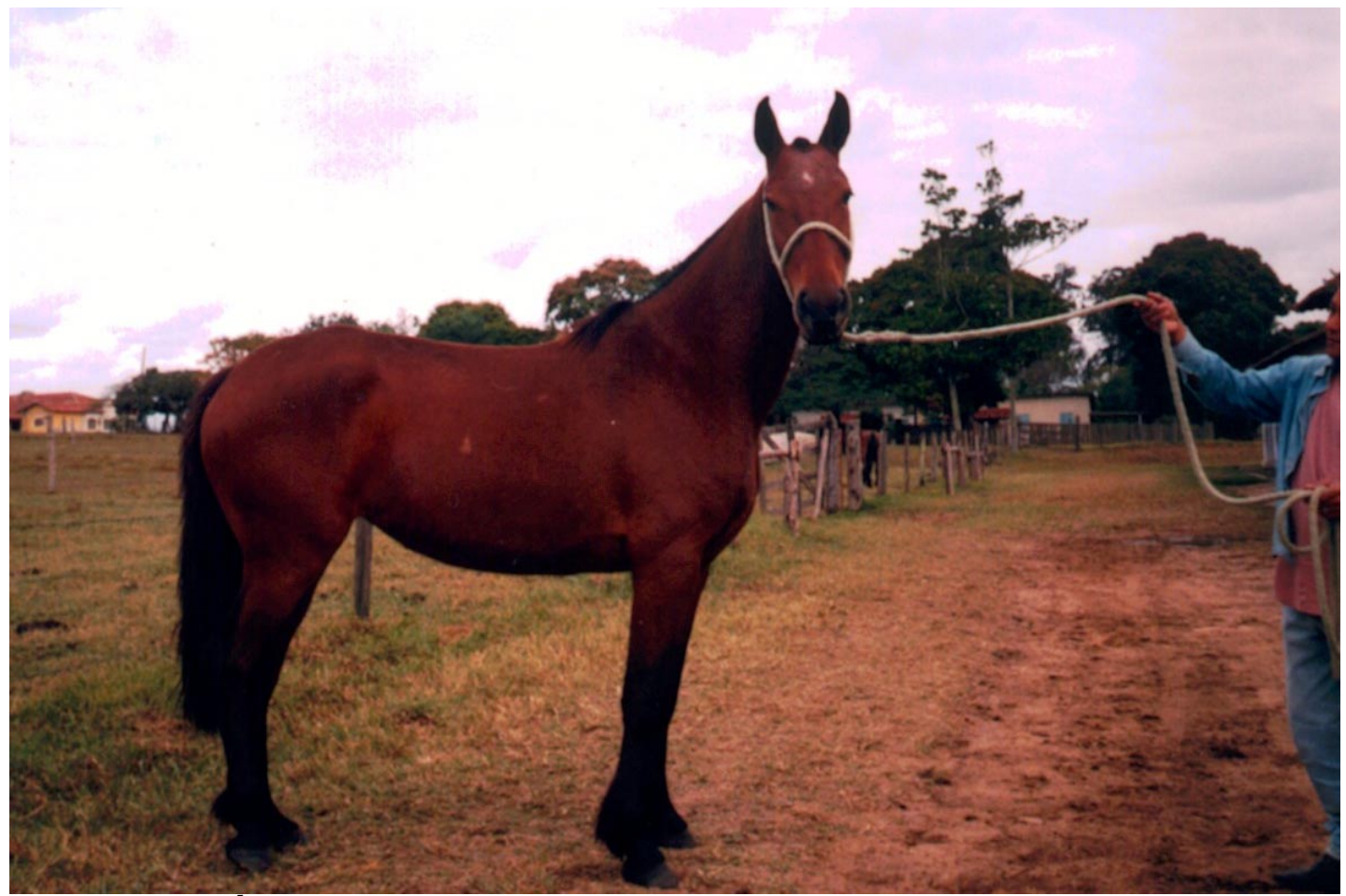

Figura 4: Égua Mangalarga Marchador - Felina, 5 anos, Bloco II. 


\subsection{Dietas e procedimento ex perimental}

O experimento teve duração total de 26 dias, sendo composto de um período de 21 dias para adaptação e avaliação de consumo voluntário (FASE I), e 5 dias para colheita de fezes (FASE II). Os tratamentos consistiram de 4 rações contendo 4 diferentes níveis $(0,25,50$ e 75\%) de FVA, em substituição ao MDPS, formulados de tal forma a serem isoprotéicas e isocalóricas. O parâmetro de substituição utilizado foi o peso, visto que fixamos a quantidade máxima total do MDPS/FVA na ração concentrada, em 75\%. Logo, ocorreu substituição de $0,33 \%$, 66\% e 100\% do MDPS pelo FVA.

A composição centesimal e química das rações experimentais e dos ingredientes encontra-se nas tabelas 2,3 e 4 , respectivamente.

Tabela 2: Composição centesimal dos ingredientes das rações experimentais T1, T2, T3 e T4 com os respectivos níveis de substituição do MDPS pelo FVA: 0, 33, 66 e $100 \%$.

\begin{tabular}{lcccc}
\hline Ingredientes & $\boldsymbol{T 1}$ & $\boldsymbol{T} 2$ & $\boldsymbol{T 3}$ & $\boldsymbol{T 4}$ \\
\hline Rolão de milho (MDPS) & 75,00 & 50,00 & 25,00 & 0,00 \\
Farelo de vagem de algaroba (FVA) & 0,00 & 25,00 & 50,00 & 75,00 \\
Farelo de soja & 7,28 & 6,72 & 6,64 & 3,32 \\
Farelo de trigo & 14,73 & 14,11 & 15,85 & 19,07 \\
Calcário calcítico & 1,99 & 3,17 & 1,51 & 1,61 \\
Sal comum & 1,00 & 1,00 & 1,00 & 1,00 \\
\hline Total & $\mathbf{1 0 0 , 0 0}$ & $\mathbf{1 0 0 , 0 0}$ & $\mathbf{1 0 0 , 0 0}$ & $\mathbf{1 0 0 , 0 0}$ \\
\hline
\end{tabular}

Tabela 3: Composição química das rações experimentais T1, T2, T3 e T4 com os respectivos níveis de substituição do MDPS pelo FVA: 0, 33, 66 e 100\%.

\begin{tabular}{ccccccc}
\hline \multicolumn{7}{c}{ Nutrientes (\% $\boldsymbol{n a} \boldsymbol{M S})$} \\
\hline Tratamentos & $\boldsymbol{E B}(\mathbf{k c a l} / \mathbf{k g})$ & $\boldsymbol{P B}$ & $\boldsymbol{F D N}$ & $\boldsymbol{F D} \boldsymbol{A}$ & $\boldsymbol{C a}$ & $\boldsymbol{P}$ \\
T1 & $3.504,29$ & 10,23 & 24,56 & 11,99 & 0,78 & 0,275 \\
T2 & $3.298,89$ & 10,38 & 26,53 & 15,70 & 1,20 & 0,205 \\
T3 & $3.404,31$ & 10,33 & 24,58 & 15,52 & 0,78 & 0,230 \\
T4 & $3.418,70$ & 10,40 & 23,55 & 14,90 & 0,93 & 0,220 \\
\hline $\boldsymbol{D P}^{1}$ & 84,26 & 0,07 & 1,25 & 1,73 & 0,198 & 0,030 \\
\hline
\end{tabular}

${ }^{1}$ Desvio Padrão.

A quantidade de alimento fornecido aos animais foi estabelecida segundo as 
recomendações do NATIONAL RESEARCH COUNCIL (NRC, 1989), visando atender as exigências nutricionais para a categoria. Portanto, na fase de adaptação, os animais receberam dietas equivalentes a $1,7 \%$ do seu peso vivo, em matéria seca ao ar (90\% MS - NRC, 1989) constituídas de 60\% feno de Coast cross (Cynodon dactylon cv. Coast cross) picado e $40 \%$ de concentrado.

Tabela 4: Composição química dos ingredientes utilizados (\% na MS).

\begin{tabular}{|c|c|c|c|c|c|c|c|}
\hline Ingredientes & $M S$ & $P B$ & $F D N$ & $F D A$ & $E B(\mathrm{kcal} / \mathrm{kg})$ & $C a$ & $\boldsymbol{P}$ \\
\hline Rolão de Milho (MDPS) & 88,50 & 7,58 & 26,14 & 13,11 & $3.619,35$ & 0,08 & 0,16 \\
\hline $\begin{array}{l}\text { Farelo de vagem de } \\
\text { algaroba (FVA) }\end{array}$ & 87,09 & 8,34 & 25,26 & 18,89 & $3.464,99$ & 0,25 & 0,10 \\
\hline Farelo de soja & 88,39 & 40,45 & 9,76 & 17,03 & $3.596,10$ & 0,33 & 0,34 \\
\hline Farelo de trigo & 88,38 & 13,25 & 33,19 & 11,45 & $3.475,25$ & 0,11 & 0,79 \\
\hline Calcário calcítico & - & - & - & - & - & 32,00 & - \\
\hline Sal comum & - & - & - & - & - & - & - \\
\hline Feno de Coast cross & 89,00 & 4,52 & 67,74 & 36,95 & $3.363,02$ & 0,31 & 0,13 \\
\hline
\end{tabular}

O período de adaptação foi dividido em 4 subfases:

(a) $1^{\mathrm{o}}$ ao $5^{\mathrm{o}}$ dia: os animais permaneceram confinados nas baias durante os períodos diurnos, recebendo $1 / 3$ da dieta total preconizada, subdividida em 2 refeições (8:00 e 14:00 h). Às 17:00 h as éguas eram soltas para um piquete onde complementavam sua alimentação em pasto de gramíneas misto até a manhã seguinte (7:00 h), quando eram presas novamente.

(b) $6^{\circ}$ ao $10^{\circ}$ dia: os animais passaram a receber $2 / 3$ da dieta, divididos igualmente às 8:00 e 18:00 h. O horário de pastejo foi modificado para 12:00 às 16:00 h, com o objetivo de reduzir este tempo e elevar o consumo da dieta fornecida no cocho.

(c) $11^{\circ}$ ao $15^{\circ}$ dia: a partir desta fase os animais permaneceram confinados 24 h, sendo exercitados diariamente cerca de 10 minutos, visando a manutenção da saúde podal (caminhada 2 a 2 no cabresto ao redor do galpão onde se instalou o experimento). A alimentação passou a ser fornecida 3 vezes diariamente (8:00, 13:00 e 18:00 h), ainda constituindo $2 / 3$ da dieta total preconizada. A partir deste período passou-se a colheita e pesagem de sobras de alimento do cocho e no chão.

(d) $16^{\circ}$ ao $21^{\circ}$ dia: o manejo foi o mesmo adotado na fase anterior, apenas modificando o fornecimento da dieta que passou a ser integral às éguas (3/3), 
conforme tabela NRC (1989) e proporções anteriormente citadas. Para que o fornecimento de alimento fosse ad libitum, acrescentava-se a dieta 10\% (consumo total, mantendo relação concentrado:volumoso) quando se observava pouca sobra.

\subsection{Metodologia de colheitas}

\subsubsection{Ensaio de digestão}

$\mathrm{Na}$ fase experimental II foram efetuadas as colheitas total e parcial de fezes para determinação dos coeficientes de digestibilidade aparente da MS, MO, PB, FDA, FDN, HCEL e da EB utilizando-se para isso, as equações propostas por CHURCH (1993).

A colheita total foi feita num período de 24 horas durante os 5 dias da FASE II. As fezes foram colhidas diretamente do piso (figura 5), acondicionadas em baldes plásticos identificados por animal, e pesadas periodicamente nos seguintes horários: 13:00 h (período designado manhã - 8:00 às 13:00h), 18:00 h (tarde - 13:00 às 18:00h), 24:00 h (noite - 18:00 às 24:00h) e 8:00 h (madrugada - 24:00 às 8:00h). Cada conjunto destes horários constituía um dia de colheita. Após homogenização e pesagem nos baldes foram colhidas alíquotas de $10 \%$ da produção fecal medida dentro do período. Estas amostras foram acondicionadas em sacos plásticos, devidamente identificadas, e refrigeradas para posterior armazenagem em freezer, com temperatura variando de $-5^{\circ} \mathrm{C} \mathrm{a}-10^{\circ} \mathrm{C}$.

A colheita parcial de fezes foi realizada uma vez em cada um dos períodos (manhã, tarde e noite). Amostras entre 150 e $250 \mathrm{~g}$ foram colhidas imediatamente após defecação, na superfície da massa fecal, evitando assim contato com o piso. Após pesagem e identificação, este material foi refrigerado e posteriormente armazenado em freezer, com temperatura variando de $-5^{\circ} \mathrm{C}$ a $-10^{\circ} \mathrm{C}$.

As sobras de alimento desta fase foram pesadas e amostradas diariamente, bem como identificadas e armazenadas tal qual as fezes para posteriores análises. 


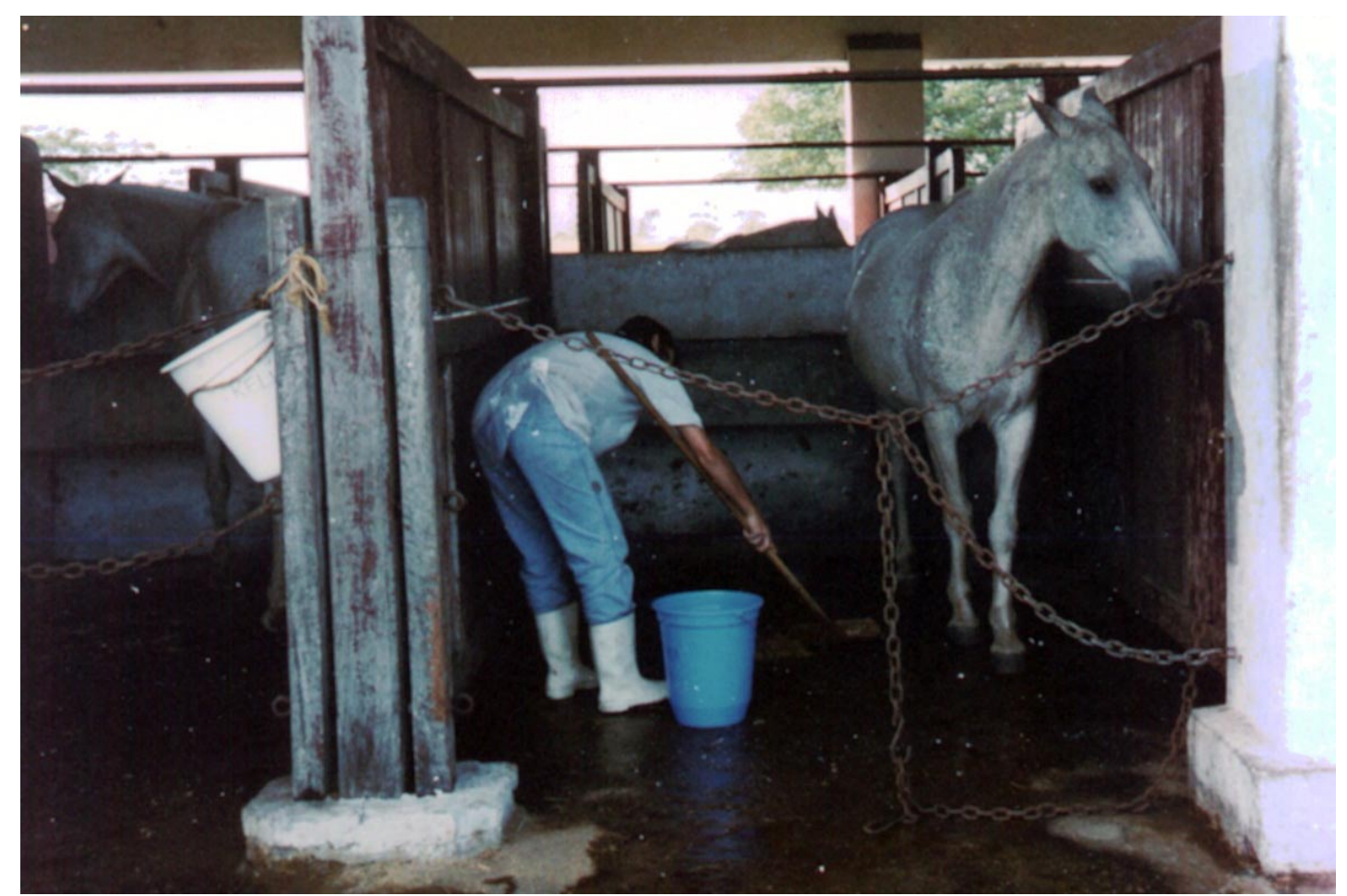

Figura 5: Colheita de amostras no piso.

\subsubsection{Viabilidade econômica d a substituição}

O levantamento do custo da ração foi efetuado no estado da Bahia nas cidades de Feira de Santana, Itabuna, Jequié, Salvador e Vitória da Conquista, no período de 17 a 28 de junho de 2002. Utilizaram-se como critérios para escolha das cidades a criação eqüina e a atividade agropecuária da região, bem como a distância do pólo hipoteticamente distribuidor do farelo de vagem de algaroba. ${ }^{1}$

Os estabelecimentos onde os dados foram colhidos caracterizam-se por serem revendedores de pelo menos três dos ingredientes do concentrado. A amostragem atingiu cerca de $70 \%$ dos estabelecimentos em cada cidade pesquisada.

O cálculo por quilo de ração foi feito a partir dos preços pesquisados e das quantidades dos ingredientes das 4 rações avaliadas. $\mathrm{O}$ farelo de vagem de algaroba foi cotado a partir do custo de produção (RIOCON ${ }^{\circledR}$ ) agregando-se a este valor o

${ }^{1}$ RIOCON ${ }^{\circledR}$ : Fazendas Reunidas Rio de Contas Ltda. Distrito de Catingal. Município de Manoel Vitorino. Região da Serra da Pipoca - Bahia. Forneceu o FVA para experimento, porém não comercializa o farelo puro: apenas o incorpora a seus produtos (rações animais). 
frete, mão de obra (descarregar) e margem de lucro (fixa em 10\%) em cada uma das cidades pesquisadas.

Não havendo disponibilidade da informação, no mercado pesquisado, considerou-se como preço do rolão de milho (MDPS) $82 \%$ do preço do milho (grão) na mesma região, com base nos seguintes critérios:

a relação nutricional observada entre o MDPS e o milho é de 0,84 , considerando uma média ponderada a partir da contribuição em energia e proteína do MDPS no volume total destes nutrientes nas rações;

a relação de preços entre o MDPS e o milho, pesquisada em revendedores na $2^{\mathrm{a}}$ quinzena de julho (2002), nas cidades de Mogi Mirim, Limeira e Pirassununga, estado de São Paulo, é de 0,79.

Através da relação nutricional lança-se mão de um ou outro insumo, baseando-se no custo-benefício. Além disso, sabe-se que o MDPS é um insumo inerente à produção do milho em grão, porém com características de produção de autoconsumo. Sendo assim, o tipo de produção, colheita, transporte, processamento e comercialização destes insumos geram uma relação de preços MDPS/Milho relativa, funcional para qualquer região no Brasil.

O fato de que a relação entre MDPS/Milho no mercado (São Paulo) observada está abaixo da relação nutricional calculada pode ser explicado pela diferença nos custos de transporte por unidade de massa $(\mathrm{kg})$ : sendo o MDPS menos denso, o frete por kg acaba sendo mais caro.

O apêndice 1 detalha todo cálculo efetuado para se chegar ao preço do MDPS.

\subsection{Processamento e análise das amostras}

Amostras compostas de fezes dos períodos da colheita total (manhã, tarde, noite e madrugada) por animal/dia foram feitas ao final de cada dia. Assim, foram congeladas 5 amostras (5 dias) de cada animal, totalizando 80 amostras.

Após o período de colheitas, as amostras foram descongeladas e feitas uma única amostra composta dos 5 dias, por animal. Deste conteúdo foram separadas 
alíquotas de 200 g para secagem em estufa de ventilação forçada a $65^{\circ} \mathrm{C}$, por 48 horas, sendo posteriormente moídas em moinho com peneira de $1 \mathrm{~mm}^{2}$ para as futuras análises laboratoriais.

Amostras da colheita parcial também foram homogenizadas por animal no período dos 5 dias, e uma amostra composta dos períodos de colheita (manhã, tarde e noite) foi utilizada para as análises. Para as sobras procedeu-se da mesma maneira: fez-se uma amostra composta referente aos 5 dias de colheita, por animal.

As análises bromatológicas dos alimentos, sobras e fezes foram realizados segundo a metodologia descrita por SILVA (1990b). Os teores de FDAi e CELi nas amostras foram obtidos após incubação in vitro dessas amostras em líquido ruminal, por 144 horas, segundo a metodologia descrita por COCHRAN et al. (1986). A metodologia usada para estimar CIA $(\mathrm{HCl} 2 \mathrm{~N})$ foi descrita por VAN KEULEN e YOUNG (1977).

\subsection{Processamento da vagem de algaroba}

Após a colheita, que se dá pela catação das vagens maduras que caem no chão, o seguinte processamento da vagem para a obtenção do farelo de vagem algaroba foi utilizado:

Trituração: as vagens foram picadas através de uma picadeira produzida sob encomenda da fábrica. Este equipamento assemelha-se ao sistema da betoneira (misturadora de concreto) compondo-se essencialmente de boca receptora das vagens, rolo condutor que impede o acúmulo das vagens na boca, e o conjunto de facas picadoras.

Condução e armazenagem: as vagens picadas foram então conduzidas por elevadores de caneca até os silos onde permanecem estocadas. Estes silos liberam o material por gravidade para a rosca sem fim que tem a finalidade de conduzi-lo para o interior da fábrica, propriamente dito, onde a vagem será transformada em farelo.

Secagem: as vagens picadas foram recebidas no secador (D'Andrea ${ }^{\circledR}$ ) com aproximadamente $25 \%$ de umidade. Este equipamento foi adaptado com uma "capa" de aço que tem a finalidade de reduzir a perda de energia (calor) no 
aquecimento das vagens, e conseqüentemente, reduzir o tempo de secagem deste material. $\mathrm{O}$ aquecimento foi feito através de uma fornalha que contém tubos de aço. Os tubos são aquecidos pelo fogo e, através de um exaustor na parte interna da fábrica, o ar externo foi succionado através dos tubos, sendo então aquecido e dirigido para o interior do secador. A temperatura neste recipiente alcança $80^{\circ} \mathrm{C}$, entre 4 a 6 horas. Então, desligada a fornalha, o resfriamento naturalmente ocorreu por mais 4 a 6 horas. O período completo de secagem durou entre 10 a 12 horas, a temperatura média registrada foi de $60^{\circ} \mathrm{C}$ e o material permaneceu com 7 a $10 \%$ de umidade.

Moagem: saindo do secador, através da rosca sem fim, o material entra no moinho (Koopers $\left.{ }^{\circledR}\right)$ para ser finalmente farelado. Este aparelho é provido de facas e nele é acoplado um exaustor. $\mathrm{O}$ ar succionado pelo exaustor carreia o pó produzido na moagem e permite a queda (vácuo) do farelo no elevador de canecas que então o conduz aos silos de armazenagem e ensacamento.

O equipamento envolvido no processamento pode ser visualizado através das figuras em anexo (A, B e C).

\subsection{Formulação do modelo matemático}

Para obtenção do consumo real dos nutrientes consideramos as médias de consumo de feno e concentrado e das sobras para cada animal. Abaixo descrevemos a equação utilizada (1).

$$
\mathrm{CRN}=\frac{(\mathrm{Cc} \times \mathrm{Nc}+\mathrm{Cf} \times \mathrm{Nf})-\mathrm{S} \times \mathrm{Ns}}{100}
$$

onde:

$\mathrm{CRN}=$ consumo real de determinado nutriente (g de MS);

$\mathrm{Cc}=$ quantidade de concentrado consumida ( $\mathrm{g}$ de $\mathrm{MS})$;

$\mathrm{Nc}=$ concentração do nutriente no concentrado (\% da MS);

$\mathrm{Cf}=$ quantidade de feno consumida (g de MS);

$\mathrm{Nf}=$ concentração do nutriente no feno $(\%$ da $\mathrm{MS})$;

$\mathrm{S}=$ sobra média medida no período de colheita ( $\mathrm{g}$ de $\mathrm{MS}$ ); 
Ns = concentração do nutriente nas sobras (\% da MS $)$.

Os coeficientes de digestibilidade aparente da MS estimados através dos indicadores (CDMS Ind) foram obtidos pelas seguintes equações (2, 3 e 4):

$$
\text { CDMSInd }(\%)=100-100 \times(\mathrm{Ai} \div \text { Afe })
$$

onde:

$\mathrm{Ai}=$ concentração do indicador ingerido (\% da MS);

Afe $=$ concentração do indicador nas fezes (\% da MS).

Calculou-se a concentração do indicador ingerido da seguinte forma (3):

$$
\operatorname{Ind} . i(g)=(A f \times C f)+(A c \times C c)-(A s \times S)
$$

onde:

Ind. $\mathrm{i}=$ quantidade do indicador ingerido ( $\mathrm{g}$ de $\mathrm{MS})$;

$\mathrm{Ac}=$ concentração do indicador no concentrado (\% da MS);

$\mathrm{Af}=$ concentração do indicador no feno $(\%$ da MS $)$;

As = concentração do indicador nas sobras (\% da MS);

$\mathrm{Cc}=$ quantidade de concentrado consumida ( $\mathrm{g}$ de $\mathrm{MS}$ );

$\mathrm{Cf}=$ quantidade de feno consumida (g de MS);

$\mathrm{S}=$ sobra média medida no período de colheita ( $\mathrm{g}$ de MS).

Conhecendo esta quantidade se tem (4):

$$
\operatorname{Ai}(\%)=(\text { Ind. } 1 \div \mathrm{CMS}) \times 100
$$

onde:

$\mathrm{Ai}=$ concentração do indicador ingerido (\% da MS);

Ind. $\mathrm{i}=$ quantidade do indicador ingerido ( $\mathrm{g}$ de $\mathrm{MS})$;

$\mathrm{CMS}=$ consumo de MS (g de MS).

Abaixo seguem as equações utilizadas para estimar a excreção fecal pelo 
indicador (Exc.)(5) e sua taxa de recuperação (TR)(6):

$$
\text { Exc. }(g)=\frac{\text { Ind.i }}{\text { Ind.fe }} \quad \text { TR(\%) }=\frac{\text { Ind.exc }}{\text { Ind.i }} \times 100
$$

onde:

Ind. $\mathrm{i}=$ quantidade do indicador ingerido $(\mathrm{g}$ de $\mathrm{MS})$;

Ind.fe $=$ concentração do indicador nas fezes $(\%$ de MS $)$;

Ind.exc $=$ quantidade de indicador excretado ( $\mathrm{g}$ da MS).

A forma de avaliação estatística dos indicadores foi adotada a partir do trabalho de JONKER et al. (1998), e executada através do programa estatístico SAS (1989). Para tanto foram considerados os seguintes conceitos:

Viéz é denominada a diferença entre a estimativa do CDMS pelo indicador e a estimativa do CDMS pela colheita total.

Acurácia é a capacidade de se direcionar a atenção para aquilo que se quer observar. Está relacionado com o fato de observar o valor certo (IATROS, 2002). Portanto, é caracterizado acurado o indicador que possui um viés médio próximo ao valor zero.

Precisão é a maior ou menor proximidade entre a observação ou a previsão que foi realizada (estimativa do indicador) e o que de fato aconteceu (coeficientes calculados pela colheita total) (IATROS, 2002). Está relacionado com o fato de acertar nas quantidades. Conseqüentemente, quanto menor o desvio padrão observado para os vieses dos indicadores, mais preciso ele é.

Robustez é a caracterização do indicador que menos é influenciado por fatores alheios (peso, idade, tratamento, consumo). Para que o indicador se enquadre neste conceito, deve possuir, em relação às retas de regressão do viés versus variáveis, pequenos coeficientes angulares e de determinação $\left(\mathrm{R}^{2}\right)$, grandes erros padrões e ainda inexistência de inclinação da reta indicada por altas probabilidades estatísticas.

As estimativas do modelo foram comparadas com os valores de viés (CDMS indicador - CDMS colheita total) do grupo de dados para cada indicador. As médias 
dos vieses e os respectivos desvios padrões foram calculados. Para avaliar a acurácia dos indicadores, os vieses foram submetidos a análise de variância (teste F). Em seguida o teste Tukey foi utilizado para comparar médias e o teste $T$ para verificar sua igualdade ao valor zero (viés $=0$ ) através do PROC UNIVARIATE (SAS, 1989). A precisão das estimativas dos indicadores foi avaliada submetendo os desvios padrões dos vieses ao teste de homogenidade das variâncias (teste Levene), e a diferença entre eles foi avaliada pelo TTEST PROCEDURE (SAS, 1989). As taxas de recuperação dos indicadores foram comparadas estatisticamente ao valor 100 através do teste T utilizando novamente o PROC UNIVARIATE (SAS, 1989). A avaliação de robustez de cada indicador foi obtida regredindo o viés contra os próprios valores de CDMS estimados pelo indicador e contra outras variáveis selecionadas (tratamento, peso, idade, consumo de matéria seca) que poderiam interferir nos resultados. Para isso utilizou-se o PROC GLM (SAS, 1989). Para comparação das inclinações das retas foi usado o teste $t$-student. Os testes experimentais utilizados foram aplicados segundo MILLIKEN e JOHNSON (1984) e a probabilidade considerada foi $5 \%$.

\subsection{Delineamento experimen tal}

O delineamento utilizado para o ensaio de digestão foi em blocos casualizados, com 4 repetições em cada tratamento. Utilizou-se a variável Idade para determinação dos blocos: Bloco I: 3,5 a 5 anos; Bloco II: 5 a 9 anos; Bloco III: 13 a 17 anos; Bloco IV: 17 a 18,4 anos.

Adotou-se para análise o seguinte modelo estatístico:

Yijk $=\mu+\mathrm{Bi}+\mathrm{Tj}+$ eijk, onde:

$\mathrm{k}=$ número de animais $=1,2,3, \ldots$, e 16 ;

Yijk = valor observado dos coeficientes de digestibilidade dos nutrientes, relativo a cada indivíduo k, no bloco i, que recebeu ração com nível j de substituição do MDPS pelo FVA;

$\mu=$ estimativa de média geral;

$\mathrm{Bi}=$ efeito dos blocos, sendo $\mathrm{i}=1,2,3$ e 4;

$\mathrm{T} \mathrm{j}=$ efeito do nível de substituição do MDPS pelo FVA, sendo $\mathrm{j}=0,33,66 \mathrm{e}$ 
$100 \%$

eijk = erro aleatório inerente a cada observação Yijk, $\sim \operatorname{NID}\left(0, \sigma_{\mathrm{e}}{ }^{2}\right)$.

Para avaliação da substituição do MDPS pelo FVA, os dados do ensaio de digestibilidade (colheita total de fezes) foram submetidos à análise de variância (teste F) e regressão utilizando o PROC GLM (SAS, 1989), considerando resultados significativos a $5 \%$ de probabilidade. 


\subsection{RESULTADOS E DISC USSÃO}

\subsection{Consumo, composição e excreção}

Todas as análises de variância foram efetuadas considerando bloco e tratamento como fontes de variação. Entretanto, não houve efeito significativo de blocos para quaisquer das variáveis estudadas. Assim sendo, confirmada a não interferência desta fonte de variação (idade dos animais) sobre os resultados obtidos neste experimento, no decorrer dos resultados e discussão, não mais abordar-se-á a este respeito.

$\mathrm{Na}$ tabela 5 estão registrados os valores médios de peso vivo e de consumo dos animais durante o experimento. A substituição pelo FVA não alterou o consumo dos animais em nenhum dos parâmetros calculados. As éguas apresentaram boa aceitabilidade à dieta, não sendo observada nenhuma restrição de consumo devido ao alimento teste (FVA).

Tabela 5: Médias de peso vivo (kg) e consumo (kg MS/dia, \% PV e peso metabólico - PM) de éguas alimentadas com feno de Coast cross e concentrado (60:40\%) com diferentes níveis de substituição do MDPS pelo FVA.

\begin{tabular}{|c|c|c|c|c|}
\hline Tratamento $^{1}$ & $P V(k g)$ & $C M S(\mathrm{~kg} / \mathrm{dia})^{2}$ & $C M S(\% P V)^{2}$ & $C P M\left(g M S / k g P V^{0,75}\right)^{2}$ \\
\hline T1 & 398,25 & 6,72 & 1,72 & 75,99 \\
\hline T2 & 409,25 & 7,37 & 1,80 & 80,58 \\
\hline T3 & 367,75 & 6,57 & 1,80 & 78,46 \\
\hline T4 & 393,44 & 7,43 & 1,89 & 84,34 \\
\hline$C V(\%)^{3}$ & 6,58 & 13,70 & 12,03 & 12,58 \\
\hline
\end{tabular}

Substituição do MDPS pelo FVA: T1 = 0\%;T2 = 33\%;T3 = 66\%;T4 = 100\%.

${ }^{2}$ Análise de variância pelo teste $\mathrm{F}$ indica diferença não significativa $(\mathrm{p}>0,05)$.

${ }^{3}$ Coeficiente de variação. 
O feno oferecido aos animais caracterizou-se como de baixa qualidade possuindo um teor de PB de apenas 4,52\% e elevados percentuais de FDN e FDA de 67,74 e $36,95 \%$, respectivamente (tabela 4). Este fato provavelmente influenciou a magnitude do consumo de todos os tratamentos, considerando que uma forragem de menor qualidade limita o consumo de MS (CYMBALUK, 1990; NRC, 1989). OLIVEIRA (1995) atribuiu menor consumo de MS aos altos níveis de FDN e lignina encontrados no capim-elefante, de 84 e 11,4\%, respectivamente.

A ingestão de MS obtida foi superior às recomendações do NRC (1989) para o peso médio observado (1,68\% PV ou 6,6 kg MS/dia para animais com 392,17 kg), entretanto inferior aos 2\% PV preconizados por FRAPE (1986) e MEYER (1995).

Provavelmente o teor médio de proteína na dieta total, de $6,84 \%$, também tenha afetado a escala de consumo dos animais. ALMEIDA et al. (1998b) relataram consumo de 2,32\% PV para dietas com 7,35\% de PB, observando aumento até o nível de 14,55\% de PB. Mais tarde os mesmos autores (ALMEIDA et al., 1998c) constataram redução no consumo de MS em potros (de 7,11 kg MS/dia ou 87,25 g $\mathrm{MS} / \mathrm{kg} \mathrm{PV}{ }^{0,75}$ para 6,79 $\mathrm{kg} \mathrm{MS} /$ dia ou 84,89 g MS/kg PV ${ }^{0,75}$ ) atribuindo os resultados ao incremento da proteína, dos carboidratos solúveis e amido, ao utilizar maiores proporções de milho e/ou soja ( $60 \%$ do concentrado).

A ingestão diária média de PB calculada, de $1,24 \mathrm{~g} / \mathrm{kg} \mathrm{PV}$, foi muito próxima da recomendação do NRC (1989) para animais em manutenção consumindo dietas de baixa qualidade $(1,30 \mathrm{~g} / \mathrm{kg} \mathrm{PV})$. Entretanto, para os tratamentos com níveis de substituição 0, 33, 66 e 100\% de MDPS por FVA, os consumos de ED de 9,91, 9,27, 7,78 e 9,54 Mcal/kg de MS, respectivamente, estiveram em média 30,42\% abaixo das exigências do NRC (1989) preconizadas para a categoria de manutenção com peso médio de $392,17 \mathrm{~kg}$. Atribuiu-se estes resultados à baixa qualidade do feno, anteriormente discutida, fornecida aos animais.

Os dados de consumo são superiores aos obtidos por VERMOREL et al. (1997), que relataram consumos de 5,78 kg MS/dia e 58,2 g MS/kg MS PV ${ }^{0,75}$. Entretanto são inferiores aos de ARAÚJO (1999) que obteve 1,96 e 2,11\% PV em dietas mistas para cavalos. OLIVEIRA et al. (1995) e OLIVEIRA et al. (2001a) também obtiveram CMS inferior aos do presente trabalho. No entanto, ao compararse os consumos em percentual de PV ou PM, os resultados obtidos por ambos autores 
foram superiores aos deste trabalho. A disparidade entre os valores deve-se, em parte, as categorias dos animais utilizadas nos experimentos, animais jovens e adultos.

A composição química das fezes está apresentada na tabela 6. A substituição do MDPS pelo FVA afetou de forma quadrática as quantidades de FDA e de EB excretadas nas fezes (figura 6). A resposta observada pode ser explicada em função do teor de FDA no concentrado que se eleva com a inclusão da FVA (tabela 3). Apesar do farelo de trigo também contribuir com o conteúdo de fibras na dieta (tabela 4), a proporção utilizada deste ingrediente nas rações com $66 \%$ e 100\% de substituição do MDPS pelo FVA não justificaria o aumento de excreção de fibras nas fezes. Estes resultados indicam que o teor de FVA influenciou as diferentes respostas obtidas nos diferentes tratamentos.

Tabela 6: Composição química média fecal de éguas consumindo feno de Coast cross e concentrado (60:40\%) com diferentes níveis de FVA em substituição ao MDPS.

\begin{tabular}{|c|c|c|c|c|c|c|}
\hline \multirow[b]{2}{*}{ Tratamentos } & \multicolumn{6}{|c|}{ Nutrientes (\% na MS) } \\
\hline & MS total ${ }^{3}$ & $M M^{3}$ & $P B^{3}$ & $F D N^{3}$ & $F D A^{*}$ & $E B(M c a l / k g) *$ \\
\hline T1 & 23,89 & 5,98 & 6,17 & 74,50 & 45,69 & 3,98 \\
\hline $\mathbf{T 2}$ & 25,49 & 6,18 & 5,85 & 73,66 & 44,00 & 4,16 \\
\hline T3 & 21,57 & 5,94 & 5,90 & 76,28 & 47,34 & 4,16 \\
\hline T4 & 24,47 & 5,76 & 5,52 & 75,30 & 49,17 & 4,00 \\
\hline$C V(\%)^{2}$ & 11,98 & 7,38 & 8,66 & 2,40 & 1,59 & 1,70 \\
\hline
\end{tabular}

Substituição do MDPS pelo FVA: T1 $=0 \% ; \mathrm{T} 2=33 \% ; \mathrm{T} 3=66 \% ; \mathrm{T} 4=100 \%$.

${ }^{2}$ Coeficiente de variação.

${ }^{3}$ Análise de variância pelo teste $\mathrm{F}$ indica diferença não significativa $(\mathrm{p}>0,05)$.

* Diferença significativa (teste $\mathrm{F}, \mathrm{p}<0,05)$ com efeitos quadráticos para FDA $\left(\mathrm{y}=0,0008 \mathrm{x}^{2}-\right.$ $\left.0,0361 x+45,357, R^{2}=0,7726, p=0,001\right)$ e para $E B\left(y=-0,000075 x^{2}+0,0077 x+3.9831, R^{2}=0,49\right.$, $\mathrm{p}=0,001)$.

A maior excreção de EB nas fezes possivelmente seja reflexo da menor digestibilidade de compostos fibrosos, abordada futuramente (subdivisão 4.2). O percentual dos demais nutrientes, MS total, MM, PB e FDN, não se mostrou significativamente diferente entre os tratamentos.

De acordo com as equações de regressão obtidas (tabela 6), os teores máximos de FDA (49,75\%) e EB (4,18 Mcal/kg MS) excretados nas fezes foram alcançados com 100 e 51,37\%, e os mínimos (44,95\% e 4,00 Mcal/kg MS) com 
23,10 e $100 \%$ de substituição do FVA pelo MDPS, respectivamente.
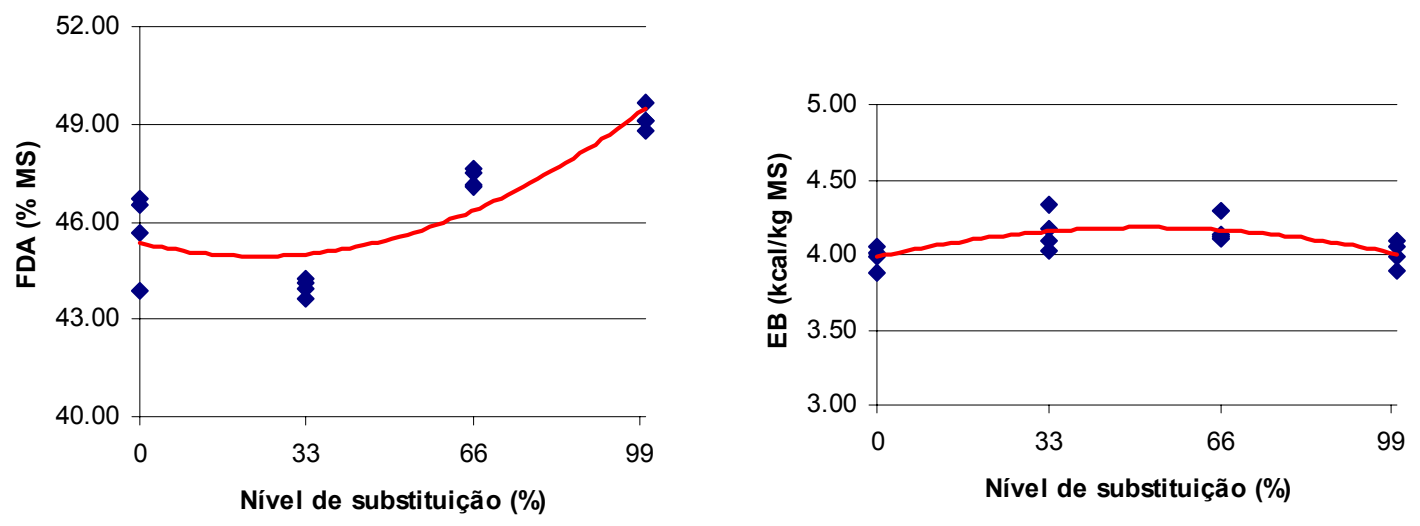

Figura 6: Comportamento dos nutrientes FDA e EB excretados nas fezes de éguas consumindo feno de Coast cross e concentrado $(60: 40 \%)$ com diferentes níveis de FVA em substituição ao MDPS.

A produção diária de fezes obtida através da colheita total foi de $3,25,3,67$, 3,44 e 3,89 kg de MS/dia, para os tratamentos com 0,33, 66 e 100\% de substituição do MDPS pelo FVA, respectivamente.

Discordando dos resultados deste trabalho, MEYER (1995) estima a produção diária de fezes de 1 a $3 \%$ PV, dependendo da quantidade e qualidade do alimento ingerido. No entanto a composição descrita está de acordo com os resultados obtidos, com exceção do teor de proteína: 75\% água, 2 a $8 \%$ cinzas bruta, 1 a $4 \%$ PB e 5 a $10 \%$ FB (MEYER, 1995).

CYMBALUK (1990) relatou teores de umidade de fezes, de 74,7 a $81 \%$, similares a este trabalho, variando conforme o tipo de forragem. FRAPE (1986) admite, entretanto, para animais saudáveis teores entre 58 e $62 \%$, relatando que este não é um parâmetro muito influenciado pela alimentação. HARRIS e RODIEK (1993) mediram o teor de água das fezes em eqüinos alimentados com feno e diferentes proporções de polpa de beterraba e não observaram diferenças entre as dietas, com teores variando entre 74 e $76 \%$.

Pela avaliação dos parâmetros de consumo, composição e excreção, acima discutidos, não existem fatores que inviabilizem a substituição do MDPS pelo FVA em até $100 \%$, em rações para eqüinos em manutenção. 


\subsection{Digestibilidade das dieta s}

Na tabela 7 podem-se observar os valores médios de CDMS, CDMO, CDPB CDHCEL, CDFDN, CDFDA e CDEB das dietas. Não foram mostradas diferenças significativas entre os tratamentos para os coeficientes de digestibilidade da MS, MO, PB e HCEL das dietas. Resultados semelhantes foram relatados por TALPADA e SHUKLA (1988) e BARROS e QUEIRÓZ FILHO (1982) que, empregando níveis de VAT até 30 e 76,39\% no concentrado para vacas e carneiros, respectivamente, também não detectaram diferenças na digestibilidade dos nutrientes MS e PB entre os tratamentos.

Tabela 7: Coeficientes de digestibilidade aparente (CD) da MS, MO, PB, HCEL, FDN, FDA e EB de éguas consumindo feno de Coast cross e concentrado (60:40\%) com diferentes níveis de FVA em substituição ao MDPS.

\begin{tabular}{cccccccc} 
& \multicolumn{7}{c}{$\boldsymbol{C D}(\%)$} \\
\hline Tratamentos $^{1}$ & $\boldsymbol{M S}^{2}$ & $\boldsymbol{M O}^{2}$ & $\boldsymbol{P B}^{2}$ & $\boldsymbol{H C E L}^{2}$ & $\boldsymbol{F D N} \boldsymbol{N}^{*}$ & $\boldsymbol{F D} \boldsymbol{A}^{* *}$ & $\boldsymbol{E B}^{* *}$ \\
\hline T1 & 51,35 & 52,61 & 56,28 & 40,00 & 27,48 & 16,50 & 43,30 \\
T2 & 50,05 & 51,10 & 57,65 & 34,43 & 27,67 & 22,26 & 37,70 \\
T3 & 47,66 & 48,72 & 55,38 & 30,17 & 19,52 & 11,24 & 35,20 \\
T4 & 47,54 & 48,30 & 58,24 & 37,13 & 20,70 & 7,90 & 37,93 \\
\hline $\boldsymbol{C V} \boldsymbol{( \% )}^{3}$ & 4,86 & 4,62 & 7,38 & 12,65 & 16,61 & 27,33 & 7,17 \\
\hline
\end{tabular}

${ }^{1}$ Substituição do MDPS pelo FVA: T1 = 0\%;T2 = 33\%;T3 = 66\%;T4 =100\%.

${ }^{2}$ Análise de variância pelo teste $\mathrm{F}$ indica diferença não significativa entre os dados $(\mathrm{p}>0,05)$.

${ }^{3}$ Coeficiente de variação.

* Análise de variância indica diferença significativamente entre os tratamentos (teste $\mathrm{F}, \mathrm{p}<0,05$ ), com efeito linear para CDFDN $\left(y=-0,0853 x+28,089, R^{2}=0,3793, p=0,0105\right)$.

** Análise de variância indica diferença significativamente entre os tratamentos (teste $\mathrm{F}, \mathrm{p}<0,05$ ), com efeitos quadráticos para CDFDA $\left(y=-0,002 \mathrm{x}^{2}+0,0891 \mathrm{x}+17,751, \mathrm{R}^{2}=0,5263, \mathrm{p}=0,0468\right)$ e para CDEB $\left(y=0,0019 x^{2}-0,2441 x+43,402, R^{2}=0,629, p=0,0147\right)$.

Os valores de digestibilidade obtidos neste trabalho estão, em média, abaixo de muitos trabalhos na literatura citados na tabela 1. Apesar das diferenças entre dietas e condições experimentais, em geral, influenciarem nos resultados, a magnitude dos coeficientes de digestibilidade deve ter sido afetada pela qualidade do feno utilizado. BARBOSA (1977) realizou 2 experimentos com carneiros aos quais forneceu exclusivamente vagens de algaroba sob diferentes tratamentos (vagens inteiras ou trituradas, aquecidas ou não por 2 horas $80^{\circ} \mathrm{C}$ ) e capim-elefante + vagens de algaroba submetidas aos mesmos tratamentos (razão 1:1,6, na MS). Confrontando 
os resultados dos ensaios, observaram-se menores coeficientes de digestibilidade quando as vagens foram consumidas com o capim-elefante. A diferença foi atribuída à qualidade do capim utilizado.

Obteve-se diferença significativa entre os tratamentos para os coeficientes de digestibilidade aparente da FDN, FDA e EB $(\mathrm{p}<0,05)$. A figura 7 ilustra os efeitos linear e quadrático detectados nas digestibilidades da FDN e FDA $(p=0,0105$ e $p=$ 0,0468, respectivamente) proporcionado pela substituição progressiva de MDPS pelo FVA. De acordo com as equações obtidas, o ponto máximo de digestibilidade da FDA (18,74\%) é atingido com 22,27\% de substituição, enquanto que, para a FDN, a maior digestibilidade $(28,09 \%)$ se dá com $0 \%$ de substituição do MDPS pelo FVA.
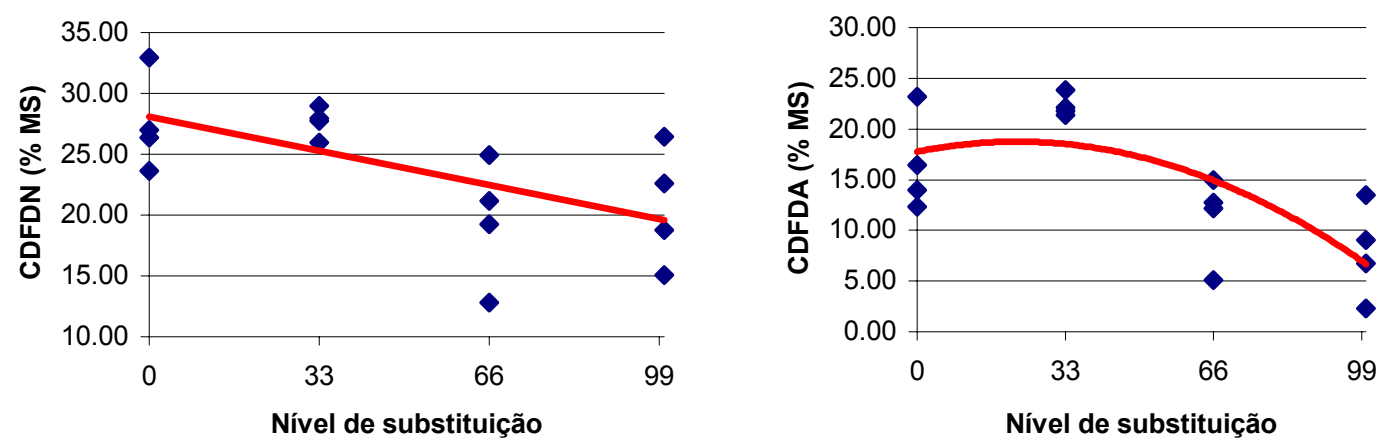

Figura 7: Comportamento dos coeficientes de digestibilidade aparente das fibras em éguas consumindo feno de Coast cross e concentrado (60:40\%) com diferentes níveis de FVA em substituição ao MDPS.

A vagem da algarobeira tem em sua composição $28,1 \%$ de casca caracterizada como dura e fibrosa, com teores de FB, de 31,6\% e FDA, de 37,5\%, segundo DEL VALLE et al. (1983). É possível que os componentes fibrosos, presentes em abundância na casca da algaroba, possuam baixa digestibilidade no trato digestivo de eqüinos. TALPADA e SHUKLA, (1988) utilizando o VAT para vacas em lactação não detectaram reduções significativas na digestibilidade dos compostos fibrosos. Outros trabalhos relataram ganhos de peso equivalentes (RAVILAKA et al., 1995; SILVA et al., 1982) e melhora na produção e qualidade do leite (NOBRE, 1982; TALPADA e SHUKLA, 1990) quando se utilizou a VAT 
para ruminantes.

Apesar destes resultados contraditórios, sabe-se que a eficiência na digestão das fibras é inferior em eqüinos, comparada aos ruminantes (CYMBALUK, 1990; FRAPE, 1986). As características principais que tornam esse fato realidade são: a diferença entre as quantidades e espécies das bactérias celulolíticas existentes no ceco e cólon, em relação ao rúmen, e a maior taxa de passagem do conteúdo digestivo observada nos eqüinos (De FOMBELLE et al., 1999; FRAPE, 1986; LaCASHA, 1999).

$\mathrm{O}$ aumento da ingestão de FDN e FDA, portanto de MS, pode afetar a digestibilidade de compostos fibrosos através da elevação da taxa de passagem (LaCASHA et al., 1999; OLIVEIRA, 1995). Esta pode ser a explicação para a redução da digestibilidade de FDN e FDA quando se elevou o nível de substituição de FVA nas rações, já que rações com maiores níveis de substituição também apresentaram maiores teores destes compostos.

Aliado a estas observações, o aumento no teor de componentes indigestíveis da parede vegetal (tabela 9, CELi e FDAi) observado nas rações com FVA também sugerem a redução na digestibilidade dos componentes fibrosos quando há aumento do nível de FVA no concentrado.

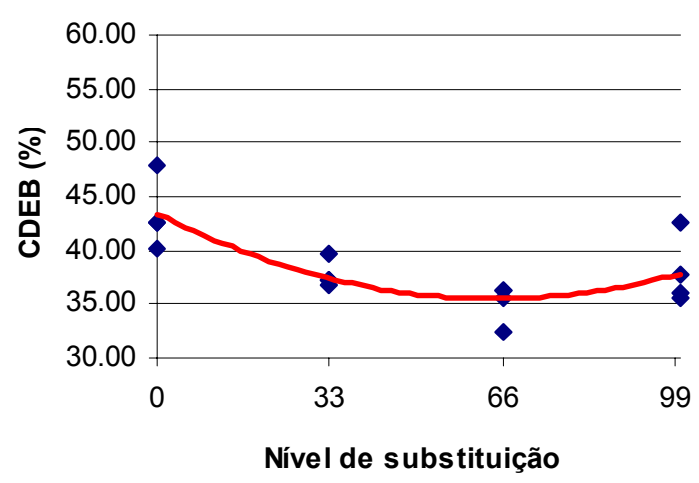

Figura 8: Resposta do CDEB em éguas consumindo feno de Coast cross e concentrado (60:40\%) com diferentes níveis de FVA em substituição ao MDPS.

Na figura 8 é ilustrado o efeito quadrático sofrido pelo CDEB $(\mathrm{p}=0,0147)$ com a substituição do MDPS pelo FVA. A maior digestibilidade $(43,40 \%)$ foi alcançada com nível 0 (zero) de substituição, enquanto a menor $(35,56 \%)$ com nível 
de $64,24 \%$ de substituição. Divergindo deste resultado TALPADA e SHUKLA (1988) e BARROS e QUEIRÓZ FILHO (1982) não observaram efeitos sobre o CDEB quando forneceram VAT no concentrado para vacas lactantes e carneiros, respectivamente.

Os principais produtos da fermentação dos carboidratos estruturais, tanto em eqüinos quanto em ruminantes, são os $\mathrm{AGV}$ que se constituem a principal fonte de energia para os eqüinos. A digestibilidade destes carboidratos está, portanto, diretamente relacionada com a curva de resposta da energia. Foi observada redução no CDEB até $64,24 \%$ de substituição pelo FVA, enquanto para os CDFDN e CDFDA houve reduções até $100 \%$ de substituição.

Estudos em aves, coelhos e suínos constataram piores conversões alimentares associados aos efeitos sobre consumo e/ou ganho de peso dos animais, ao substituir o milho (ou dieta referência à base de milho e soja) pela vagem de algaroba em dietas (BRANDÃO et al., 1989; ESPÍNDOLA et al., 1985; OLIVEIRA et al., 2001c; PINHEIRO et al., 1986; PINHEIRO et al., 1998; SILVA et al., 1989b). A estes efeitos também se atribuem os níveis de fibras incrementados pelo aumento de algaroba nas rações.

Por outro lado, existem trabalhos na literatura que recomendam para monogástricos a substituição entre 10 e $50 \%$ do milho pela vagem de algaroba, sem prejuízos de desempenho para animais adultos (ARAÚJO et al., 1990; ASSIS et al., 1990; LIMA et al., 1998; VANKER et al., 1998).

Outros fatores como o nível de tanino na vagem de algaroba, bem como a aceitabilidade deste ingrediente, são apontados como prejudiciais quando se trabalha com monogástricos. Os níveis de compostos fenólicos no FVA neste estudo foram obtidos (taninos $=6,6 \mathrm{~g} \cdot \mathrm{kg}^{-1} \mathrm{MS}$ e fenóis $=12,0 \mathrm{~g} \cdot \mathrm{kg}^{-1} \mathrm{MS}$, cortesia do CENA) ${ }^{2} \mathrm{e}$ estão dentro da normalidade aceitável e encontrada, por exemplo, na própria alfafa (NOZELLA, 2001). Ademais, é possível que o processamento ao qual foi submetido o FVA tenha reduzido os níveis desses compostos (ORTEGA-NIEBLAS et al., 1996). Com relação à aceitabilidade da algaroba, MARTIN - ROSSET (1993) comenta a sua apreciação pelos eqüinos. Além disso, as informações que se tem com

${ }^{2}$ CENA $=$ Centro de Estudos Nucleares na Agricultura. Piracicaba, SP. Valores expressos em mg equivalentes de Ácido Tânico. 
a prática de alguns criadores é que o FVA, assim como as vagens inteiras, é bem aceito por esta espécie animal.

Outros fatores antinutricionais, como o inibidor de tripsina e quimotripsina, atividade hemaglutinante e glicosídeos cianogênicos foram encontrados nas vagens de algaroba, porém em níveis insuficiente para provocarem efeitos sobre a digestibilidade de nutrientes (DEL VALLE et al., 1983; LIMA et al., 1983).

Considerando os resultados de digestibilidade nas condições do presente trabalho, é viável a substituição do MDPS pelo FVA em até 100\%, para eqüinos em manutenção, mesmo conhecendo as perdas na digestibilidade, principalmente dos componentes fibrosos, o que não parece comprometer a viabilidade biológica desta substituição.

\subsection{Avaliação dos indicador es internos}

Toda a avaliação dos indicadores foi realizada a partir do modelo baseado na diferença da estimativa do CDMS pelo indicador e do CDMS obtido pela colheita total, a qual denominou-se viés (JONKER et al., 1998). Estas estimativas estão apresentadas na tabela 8 e os demais resultados nas tabelas 9,10 e 11 .

Tabela 8: Coeficientes de digestibilidade aparente da matéria seca (CDMS) estimados por meio da colheita total de fezes (CT) e dos indicadores: celulose indigestível (CELi), fibra em detergente ácido indigestível (FDAi) e cinza insolúvel em ácido (CIA), em éguas alimentadas com feno de Coast cross e concentrado $(60: 40 \%)$ com diferentes níveis de substituição do MDPS pelo FVA.

\begin{tabular}{ccccc}
\hline Tratamentos $^{1}$ & $\boldsymbol{C T}$ & $\boldsymbol{F D} \boldsymbol{A} \boldsymbol{i}$ & $\boldsymbol{C E} \boldsymbol{L} \boldsymbol{i}$ & $\boldsymbol{C I A}$ \\
\hline T1 & 51,53 & 51,03 & 47,62 & 65,24 \\
T2 & 50,05 & 45,48 & 41,96 & 65,13 \\
T3 & 47,66 & 49,48 & 47,14 & 66,26 \\
T4 & 47,54 & 47,00 & 47,09 & 62,23 \\
\hline $\boldsymbol{C V}(\%)$ & 4,86 & 4,53 & 6,62 & 2,70 \\
\hline ção do MDPS pelo FVA: T1 = 0\%;T2 $=33 \% ; \mathrm{T} 3=66 \% ; \mathrm{T} 4=100 \%$. \\
cente de variação (\%)
\end{tabular}

${ }_{2}$ Substituição do MDPS Coeficicente de variação $(\%)$
( $)$ 
Tabela 9: Teor de indicadores na dieta total e em seus componentes (\% na MS).

\begin{tabular}{cccc}
\hline Dietas $^{1}$ & $\boldsymbol{F D} \boldsymbol{A i}$ & $\boldsymbol{C E L i}$ & $\boldsymbol{C I A}$ \\
\hline T1 & 16,89 & 11,58 & 0,80 \\
T2 & 18,64 & 12,58 & 0,79 \\
T3 & 18,48 & 12,30 & 0,77 \\
T4 & 19,84 & 12,77 & 0,78 \\
\hline Concentrado $^{2}$ & & & \\
\hline T1 & 7,49 & 5,94 & 0,22 \\
T2 & 11,64 & 8,31 & 0,20 \\
T3 & 11,49 & 7,77 & 0,15 \\
T4 & 14,41 & 8,67 & 0,15 \\
Feno & 23,56 & 15,58 & 1,21 \\
\hline
\end{tabular}

${ }^{1}$ Dietas contendo $60 \%$ de feno Coast cross e $40 \%$ de concentrado.

${ }^{2}$ Níveis de substituição do MDPS pelo FVA: T1 = 0\%;T2 = 33\%;T3 = 66\%;T4 = 100\%.

As medidas de acurácia dos indicadores CELi e FDAi (tabela 10), com relação à média dos vieses, não mostraram diferenças entre si pelo teste Tukey. No entanto, a FDAi mostrou-se mais acurado por apresentar média de viés igual ao valor 0 (zero), não se diferenciando, por conseguinte, da estimativa obtida pela colheita total. A média dos vieses da CIA mostrou-se significativamente diferente dos demais indicadores $(\mathrm{p}<0,05)$ assim como diferente de 0 (zero), caracterizando-se deste modo o indicador menos acurado.

Tabela 10: Comparação das estimativas de CDMS por indicadores internos através da análise do viés (CDMS indicador - CDMS colheita total de fezes).

\begin{tabular}{|c|c|c|c|}
\hline Indicadores & $F D A i$ & CELi & $C I A$ \\
\hline \multicolumn{4}{|c|}{ Acurácia } \\
\hline Médias dos vieses (\%) ${ }^{1,2}$ & $-0,9475 b$ & $-3,2406 b^{*}$ & $15,5200 \mathrm{a}^{*}$ \\
\hline Probabilidade & 0,3598 & 0,0221 & 0,0001 \\
\hline \multicolumn{4}{|c|}{ Precisão } \\
\hline Desvio Padrão $^{3}$ & 4,0092 & 5,0796 & 3,0737 \\
\hline Probabilidade & $<0,0500$ & $<0,0500$ & $<0,0500$ \\
\hline \multicolumn{4}{|c|}{ Qualidade } \\
\hline Taxa de Recuperação (\%) ${ }^{4}$ & 98,49 & $94,49 * *$ & $144,50 * *$ \\
\hline Probabilidade & 0,4554 & 0,0282 & 0,0001 \\
\hline
\end{tabular}

Letras iguais na mesma linha indicam médias iguais.

${ }^{1}$ Análise de variância (teste $\left.\mathrm{F}, \mathrm{p}=0,001\right)$ e Tukey $(\mathrm{p}<0,05)$ indicam diferença entre médias.

${ }^{2}$ Probabilidade do teste $\mathrm{T}$ de média $=0$. * Média diferente de 0 (zero).

${ }^{3}$ Teste de homogenidade das variâncias (Levene, $\mathrm{p}=0$,0142) seguido de TTEST: probabilidades correspondentes a comparações 2 a 2 .

${ }^{4}$ Probabilidade do teste $\mathrm{T}$ de média $=100 . * *$ Média diferente de $100(\mathrm{cem})$. 
PENNING e JOHNSON (1983a) avaliaram os indicadores CIA e CELi, através de incubação in situ, com vistas ao modelo descrito no presente trabalho. Alimentando ovinos com alfafa (Medicago sativa cv. Maris Phoenix) ou "ryegrass" (Lolium perenne cv. Melle) peletizados, estimaram o CDMO através dos indicadores comparando-os com os calculados através da colheita total. Os vieses de ambos indicadores foram comparados e verificou-se que, com exceção da estimativa da CELi para o "ryegrass", os vieses foram significativamente maiores do que 0 (zero) $(\mathrm{p}<0,05)$, e ainda que, os vieses encontrados para CIA foram superiores àqueles obtidos pela CELi. Atribui-se aos coeficientes de variação e às taxas de recuperação, a alta variabilidade encontrada para a CIA na predição do CDMO para animais recebendo alfafa, o que concorda com o presente trabalho. Segundo os autores, a menor digestibilidade da alfafa poderia levar a redução na taxa de passagem limitando o tempo necessário para este marcador alcançar um equilíbrio no trato gastro intestinal. Apesar da digestibilidade da MO entre colheita total e CELi não diferirem entre si, não se sabe se esses resultados poderiam ser aplicados a forragens verdes.

Avaliando o viés da FDAi em relação a colheita total em forragens diferentes (alfafa, "ryegrass" e trevo vermelho - Trifolium pratense cv. Hungaropoly) em ovinos, PENNING e JOHNSON (1983b) concluíram que a FDAi pode ser usada como um indicador confiável para predizer o CDMO em ovinos, inclusive superando a precisão dos indicadores CELi e CIA, testados previamente. Por outro lado, outros trabalhos relataram estimativas de CDMO da FDAi diferentes da colheita total (SUNVOLD e COCHRAN, 1991 e FERRET et al., 1999). Os efeitos da qualidade da dieta e das variações analíticas na extração da fibra parecem afetar a taxa de recuperação dos indicadores.

Para avaliação da precisão comparou-se os desvios padrões dos vieses dos indicadores 2 a 2. Não foram mostradas diferenças significativas entre o desvio padrão dos vieses dos indicadores. Considerando, entretanto, que o indicador é mais preciso quanto menor o desvio padrão dos vieses obtidos por ele em relação à colheita total, a CIA pode ser considerado o mais preciso entre os três.

Apenas a taxa de recuperação obtida pela FDAi não se mostrou diferir de $100 \%(\mathrm{p}=0,4554)$. Apesar deste resultado estatístico, obteve-se neste trabalho alta 
taxa de recuperação para a CELi (média $=94,49 \%$ ). As estimativas de digestibilidade da CIA foram, em média, $40 \%$ acima daquelas calculadas pela colheita total, atribuindo-se estes resultados às maiores taxas de recuperação.

A literatura preconiza o teor mínimo de $0,75 \%$ (na MS) de CIA na ração ou alimento para que a estimativa da digestibilidade por este indicador, em ruminantes, seja precisa (Thonney et al., 1985 apud ARAÚJO, 1999). SUNVOLD e COCHRAN (1991) atribuíram as super estimativas de CDMO e altas taxas de recuperação obtidas pelo indicador, em novilhos de corte, ao baixo teor de CIA no feno de alfafa $(0,3 \%)$, contudo observaram variação de acordo com a forragem utilizada (alfafa, "bromegrass" e feno de capim nativo).

No presente trabalho, apesar do feno possuir alto teor e as rações apresentarem percentuais baixos de CIA, a proporção ingerida deste indicador na dieta total se adequou ao valor preconizado na literatura (tabela 9). Vale salientar que todo o alimento que caía do cocho sobre o piso era ingerido pelos animais. ARAÚJO (1999), no entanto, obteve alta taxa de recuperação em dieta para eqüinos composta de feno Coast cross e milho (60:40\%), mesmo tendo teores de CIA insignificantes no milho; o teor de CIA no feno foi de 1,07\%. Em concordância com este autor, o controle sobre a contaminação do alimento por agentes que afetam a recuperação deste indicador seria, portanto, a possível causa das altas recuperações encontradas neste trabalho.

CUDDEFORD e HUGUES (1990) e MIRAGLIA et al. (1999) também observaram super estimativa dos coeficientes de digestibilidade estimados pela CIA em relação à colheita total em eqüinos, apesar de não existirem diferenças significativas. Todavia, existem resultados contraditórios na literatura, onde não se observam super estimativas e as taxas de recuperação aproximam-se de 100\% (ARAÚJO, 1999; ARAÚJO et al., 2000; MACHADO, 1992). Autores ressaltam, contudo, a necessidade de mais estudos nesta espécie, a fim de avaliar com segurança o potencial deste indicador.

A tabela 11 explana a avaliação de robustez de cada um dos indicadores. De acordo com as análises efetuadas, os indicadores FDAi e CELi sofreram influência das variáveis CDMS e CMS. Apesar de também ser afetada pelo CDMS, a CIA não foi influenciada pelo CMS $(p=0,0902)$. O menor coeficiente angular da reta de 
regressão CMS versus viés da CIA, comparada à dos outros indicadores, reforça este resultado.

As variáveis peso dos animais, idade e tratamento não interferiram nas estimativas de CDMS dos indicadores.

Tabela 11: Comparação das regressões obtidas a partir do viés de indicadores (CDMS indicador - CDMS colheita total de fezes) para avaliação do quesito robustez.

\begin{tabular}{|c|c|c|c|}
\hline Indicadores & $F D A i$ & $C E L i$ & $\overline{C I A}$ \\
\hline \multicolumn{4}{|c|}{ Variável $=C D M S(\%)$} \\
\hline Coef. Angular 1,2 & 0,9862 & 1,2104 & 0,6934 \\
\hline Erro Padrão & 0,2346 & 0,1952 & 0,2995 \\
\hline $\mathrm{R}^{2}$ & 0,5453 & 0,7389 & 0,2813 \\
\hline Probabilidade ${ }^{3}$ & 0,0001 & 0,0001 & 0,0255 \\
\hline \multicolumn{4}{|c|}{ Variável $=C M S(g)$} \\
\hline Coef. Angular $^{2}$ & $-2,2406$ & $-2,3833$ & $-1,4900$ \\
\hline Erro Padrão & 0,8590 & 0,8590 & 0,8590 \\
\hline $\mathrm{R}^{2}$ & 0,3645 & 0,2573 & 0,2747 \\
\hline Probabilidade & 0,0125 & 0,0082 & 0,0902 \\
\hline \multicolumn{4}{|c|}{ Variável $=$ Tratamento } \\
\hline Coef. Angular & 0,0188 & 0,0540 & 0,0191 \\
\hline Erro Padrão & 0,0272 & 0,0272 & 0,0272 \\
\hline $\mathrm{R}^{2}$ & 0,0326 & 0,1669 & 0,0574 \\
\hline Probabilidade & 0,4929 & 0,0538 & 0,4858 \\
\hline \multicolumn{4}{|c|}{ Variável $=$ Peso $(\mathrm{kg})$} \\
\hline Coef. Angular & $-0,0159$ & $-0,0167$ & $-0,0287$ \\
\hline Erro Padrão & 0,0231 & 0,0231 & 0,0231 \\
\hline $\mathrm{R}^{2}$ & 0,0338 & 0,0232 & 0,1882 \\
\hline Probabilidade & 0,4948 & 0,4751 & 0,2213 \\
\hline \multicolumn{4}{|c|}{ Variável = Idade (anos) } \\
\hline Coef. Angular & 0,0593 & 0,0617 & $-0,0464$ \\
\hline Erro Padrão & 0,1793 & 0,1793 & 0,1793 \\
\hline $\mathrm{R}^{2}$ & 0,0084 & 0,0056 & 0,0086 \\
\hline Probabilidade & 0,7426 & 0,7327 & 0,7973 \\
\hline
\end{tabular}

Os resultados de robustez ficam evidenciados em função das probabilidades estatísticas observadas quando se regrediu os vieses destes indicadores contra cada uma das variáveis. A baixa probabilidade (resultado significativo) indica a existência 
de inclinação da reta (alto coeficiente angular) e, portanto, que ela se desloca em função da variável, como se observa nas figuras 9 e 10.

FDAi

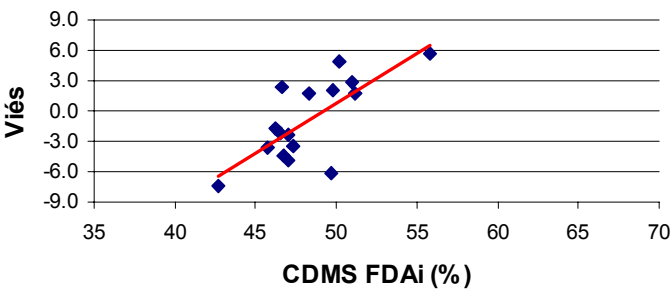

CELi

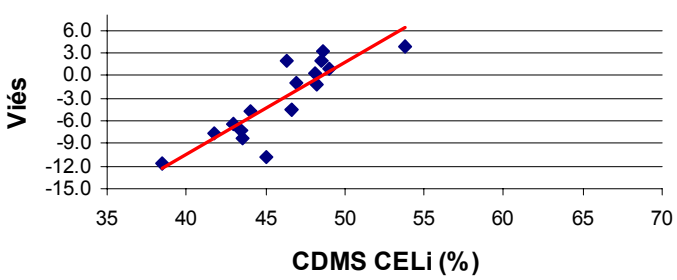

CIA

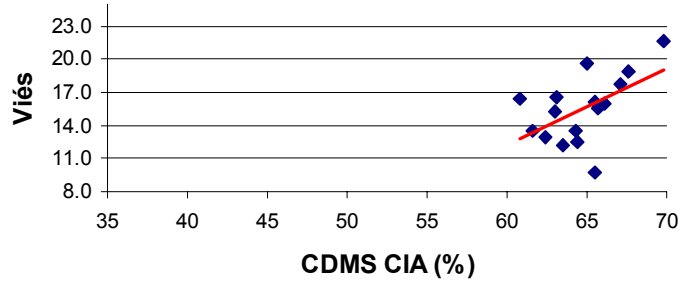

Figura 9: Curvas de regressão dos vieses dos indicadores (CDMS colheita total - CDMS indicador) contra os CDMS estimados por cada um deles (p = 0,0001). FDAi: $y=$ $0,9862 x-48,523, R^{2}=0,5453$. CELi: $y=1,2104 x-58,862, R^{2}=0,7389$. CIA: $y=0,6934 x-29,337, R^{2}=$ 0,2813 .
FDAi

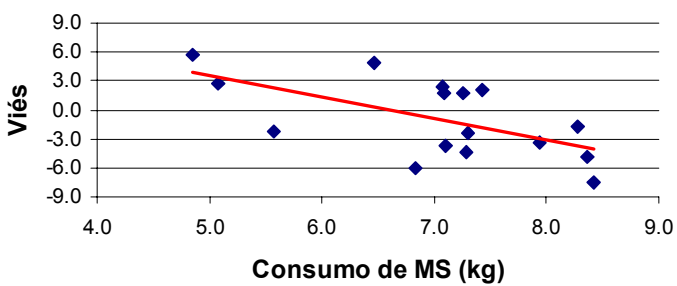

CELi

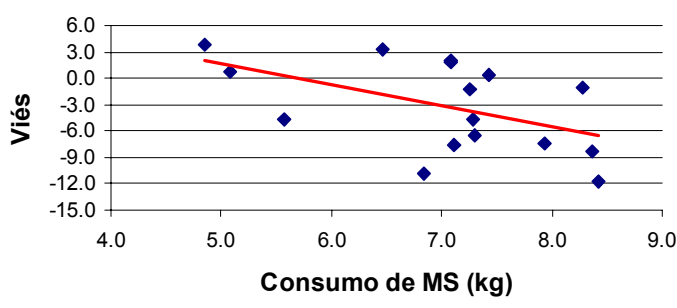

CIA

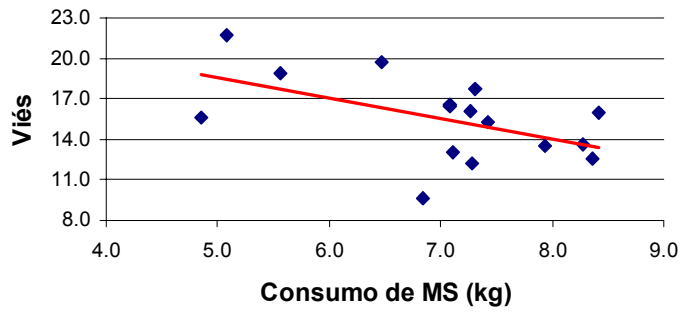

Figura 10: Curvas de regressão dos vieses dos indicadores (CDMS colheita total - CDMS indicador) contra o CMS (kg) medido $(p=$ 0,002). FDAi: $y=-2,2391 x+14,776$, $R^{2}=0,3645$. CELi: $y=-2,3832 x+$ 13,494, $R^{2}=0,2573$. CIA: $y=$ $1,4904 x+25,987, R^{2}=0,2747$. 
As comparações entre as inclinações das retas de regressão dos indicadores não se mostraram significativas, o que significa dizer que os indicadores CELi, FDAi e CIA são igualmente influenciados pelas variáveis CMS e CDMS. Ainda assim, com relação à influência do CDMS, observa-se através da figura 9 que a CELi tende a pontos mais relacionados entre si $\left(\mathrm{R}^{2}=0,7389\right)$ do que os demais indicadores, além de possuir o maior coeficiente angular entre as 3 retas comparadas, o que indica de que sofre maior interferência desta variável. O coeficiente de determinação $\left(R^{2}\right)$ e o erro padrão também demonstram a interferência da variável nas estimativas dos indicadores, pois quanto menor o erro, menor a distribuição dos pontos ao longo da reta e, quanto mais alto $\mathrm{o} \mathrm{R}^{2}$, maior a relação entre o viés e a variável, portanto, maior a interferência da variável na estimativa (figuras 9 e 10).

Indicadores internos também têm sido utilizados para estimar o fluxo de MS ileal em eqüinos, em relação ao consumo de MS. ALMEIDA et al. (1998a) encontrou super estimativas através dos indicadores FDAi e CELi. Os autores atribuíram este resultado à recuperação dos indicadores no conteúdo ileal que poderia ter sido influenciada pela possível retenção de material fibroso nas cânulas. É sugerido ainda que os níveis mais elevados de fibra (maior proporção de volumoso na dieta) podem influenciar na eficiência da estimativa destes indicadores. Mais tarde os mesmos autores (ALMEIDA et al., 2000) relataram não haver diferenças entre os coeficientes de digestibilidade da MS obtidos com a FDAi e CELi comparados à colheita total de fezes, com o percentual de recuperação fecal destes indicadores de 98,75 e $101,72 \%$, respectivamente.

Resultados diferenciados foram observados para FDAi e CELi, variando conforme a dieta (feno Coast cross exclusivo ou feno + concentrado) (ALVARENGA, 1996). Houve melhor recuperação da FDAi com a dieta exclusiva de feno (médias: 91,35 vs 76,45\%). O autor concluiu que a FDAi foi o indicador que melhor estimou valores de fluxo de MS ileal nos eqüinos fistulados.

Considerando os conceitos de acurácia, precisão e robustez, é possível pontuar falhas específicas dos indicadores, tais como o efeito do tipo de forragem/tratamento ou de variáveis que influenciam nas suas estimativas de digestibilidade. Deste modo, a aplicação progressiva deste modelo possibilitaria o mais perfeito conhecimento do potencial real do indicador. 
O modelo de avaliação utilizado e desenvolvido neste trabalho é bastante inovador; ainda assim, nas condições deste trabalho e em concordância com outros autores (ALMEIDA et al. 2000; ALVARENGA, 1996 e PENNINIG e JONHSON, 1983b), os indícios apontam a FDAi como o melhor dos indicadores estudados, seguido da CIA e por último a CELi. Para esta classificação considerou-se uma pontuação para cada quesito avaliado, sendo, para acurácia 2 pontos, precisão 1 ponto, qualidade 1 ponto, robustez 1 ponto para cada variável (CDMS, CMS, idade, peso e tratamento), somando no total 9 pontos no atendimento de todos os requisitos.

O apêndice 2 traz a composição das fezes da colheita parcial, utilizada para cálculo da digestibilidade através dos indicadores, enquanto o apêndice 3 engloba as médias de coeficientes de digestibilidade aparente estimados pelos indicadores internos, assim como os obtidos pela colheita total de fezes.

\subsection{Viabilidade econômica d a substituição MDPS por FVA}

O levantamento do custo dos alimentos e das 4 rações estudadas está demonstrado na tabela 12. Estimou-se o preço do MDPS através da média das relações com o milho (grão), baseada no aporte nutricional e nos preços entre estes insumos encontrados no estado de São Paulo. Na literatura foi encontrada relação de preços semelhante à média calculada e utilizada para este estudo $(0,82$ no período da primavera, segundo SILVA et al., 1982). Foi observado que na medida de inclusão do FVA o preço/kg de ração se elevou.

Tabela 12: Custo de alimentos e rações para eqüinos utilizando o FVA em substituição ao MDPS.

\begin{tabular}{cccccccc}
\hline Alimentos $^{1}$ & $\begin{array}{c}\text { Milho } \\
\text { (Grão) }\end{array}$ & MDPS & FVA & $\begin{array}{c}\text { Farelo } \\
\text { de Soja }\end{array}$ & $\begin{array}{c}\text { Farelo de } \\
\text { Trigo }\end{array}$ & Calcita & Sal \\
\hline $\mathrm{R} \$ / \mathrm{kg}$ & 0,362 & 0,295 & 0,366 & 0,689 & 0,246 & 0,146 & 0,128 \\
\hline Rações & T1 & T2 & T3 & T4 & & & \\
$\mathrm{R} \$ / \mathrm{kg}$ & 0,312 & 0,326 & 0,345 & 0,348 & & & \\
\cline { 1 - 5 } & &
\end{tabular}

${ }^{1}$ Média de preços entre as 5 cidades pesquisadas.

${ }^{2}$ Substituição do MDPS pelo FVA: T1 = 0\%; $22=33 \%$; $33=66 \%$; $44=100 \%$.

A viabilidade econômica para a substituição de ingredientes de rações pelo 
FVA tem sido mostrada em alguns poucos trabalhos publicados que, em sua maioria, diferem dos resultados deste estudo. SILVA et al. (1982) observaram menor custo/kg de alimento e por $\mathrm{kg}$ de carcaça produzida com $100 \%$ de substituição do farelo de trigo pela VAT (vagem de algaroba triturada) em bovinos em confinamento, refletindo a superioridade da performance dos animais e os efeitos e variação dos preços e quantidades dos alimentos utilizados. Usando a mesma substituição para vacas leiteiras, NOBRE (1982) obteve menores custos de produção de leite e de alimentação diária/vaca. O autor ressalta que, estando idênticos os custos do farelo de trigo e da vagem de algaroba, a variação foi proporcionada pelos custos e quantidades de outros alimentos, modificadas em função da entrada da VAT.

Ainda divergindo do presente estudo, autores ressaltam benefícios econômicos com a utilização da vagem de algaroba. RAVILAKA et al. (1995) observaram menor custo/kg de ganho de peso $(\mathrm{p}<0,05)$ com a inclusão de $30 \%$ de VAT em dietas para cordeiros. TALPADA e SHUKLA (1990) chegaram à conclusão que $30 \%$ de VAT no concentrado para vacas de leite reduz o custo da alimentação $/ \mathrm{kg}$ de leite produzido. Buzo et al. apud AZEVÊDO (1982) relatou (México) uma economia de 29,8\% no custo de alimentação de ovinos de engorda, utilizando $45 \%$ de farinha de vagem de algaroba na ração.

Um fato que deve ser ressaltado com relação aos trabalhos supracitados é que, os preços utilizados para análise econômica de rações contendo vagens de algaroba, aparentemente, excluem transporte, mão de obra e processamento, fatores estes considerados e agregados ao preço/kg da vagem no presente trabalho. Concluise isso a partir da falta de informações sobre processamento destas vagens, ou mesmo pela citação de que o material foi apenas triturado (VAT ao invés de FVA), levando a entender que este processo ocorreu experimentalmente, sendo desconsiderado, portanto, seu custo operacional e comercial.

A relação entre os preços da vagem de algaroba e do milho grão apresentada na literatura é da ordem de 0,70 e 0,45 segundo os autores NOBRE (1982) e SILVA et al. (1982), respectivamente. Considerando que o preço da vagem de algaroba, apenas colhida e ensacada, obtida neste estudo foi de $\mathrm{R} \$ 0,20 / \mathrm{kg}$, a sua relação com o milho grão $(\mathrm{R} \$ 0,36 / \mathrm{kg})$ é de 0,55 ; logo, um valor intermediário àqueles encontrados na literatura. 
$\mathrm{Na}$ análise de custo do presente trabalho observou-se que os preços do milho e do FVA são equivalentes (tabela 12). Porém, historicamente os preços/kg do milho já foram maiores que os do período de colheita ( $2^{\mathrm{a}}$ quinzena de junho/2002) (figura $11, \mathrm{FGV}, 2002)^{3}$. Ao longo do ano, a cotação do milho é influenciada por vários fatores, entre eles, a sazonalidade (figura 12$)^{3}$. No período de entressafra (normalmente estiagem) os preços do milho tendem a se elevar. Foi observado que o pico de produção das vagens da algarobeira coincide com o período seco, e, se este se alonga, a fase produtiva também perdura (BARBOSA, 1977; EMATERBA, 1983). Em virtude da adaptação às regiões de grandes períodos de estiagem, a algarobeira não sofre tanto as influências da sazonalidade (HAAG, 1986). Enfim, por razões estruturais ou por sazonalidade, os preços do milho podem se elevar viabilizando o uso do FVA.

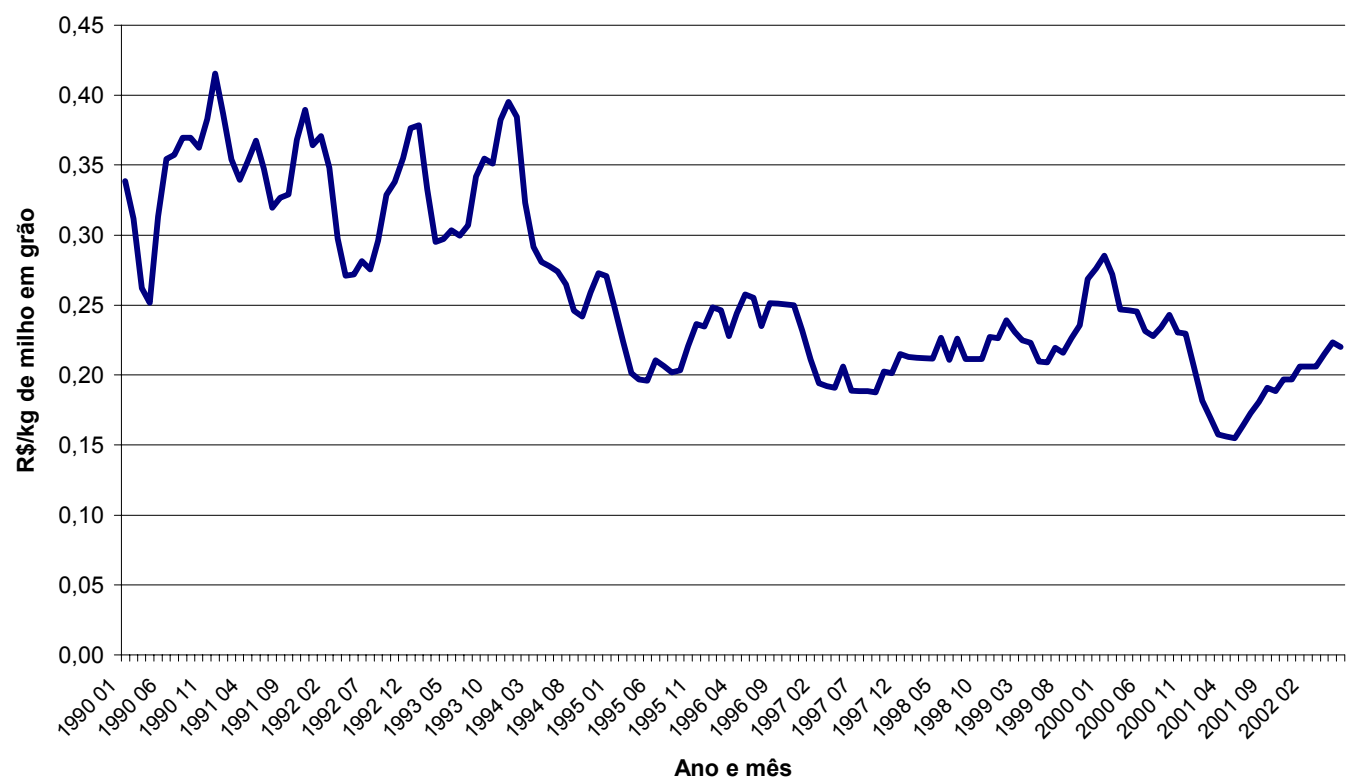

Figura 11: Cotações de preço ao produtor do milho (grão) ao longo de 10 anos, deflacionados pelo IGP-M. Elaborado a partir de dados obtidos da Fundação Getúlio Vargas FGV - Agroanalysis (2002).

\footnotetext{
${ }^{3}$ Os valores pontuados nas figuras 13 e 14 são preços ao produtor, portanto estão aquém da realidade pesquisada, já que se cotou preços de revendedores, provavelmente maiores em torno de $30 \%$ do que os valores observados.
} 
Sazonalidade dos preços do milho

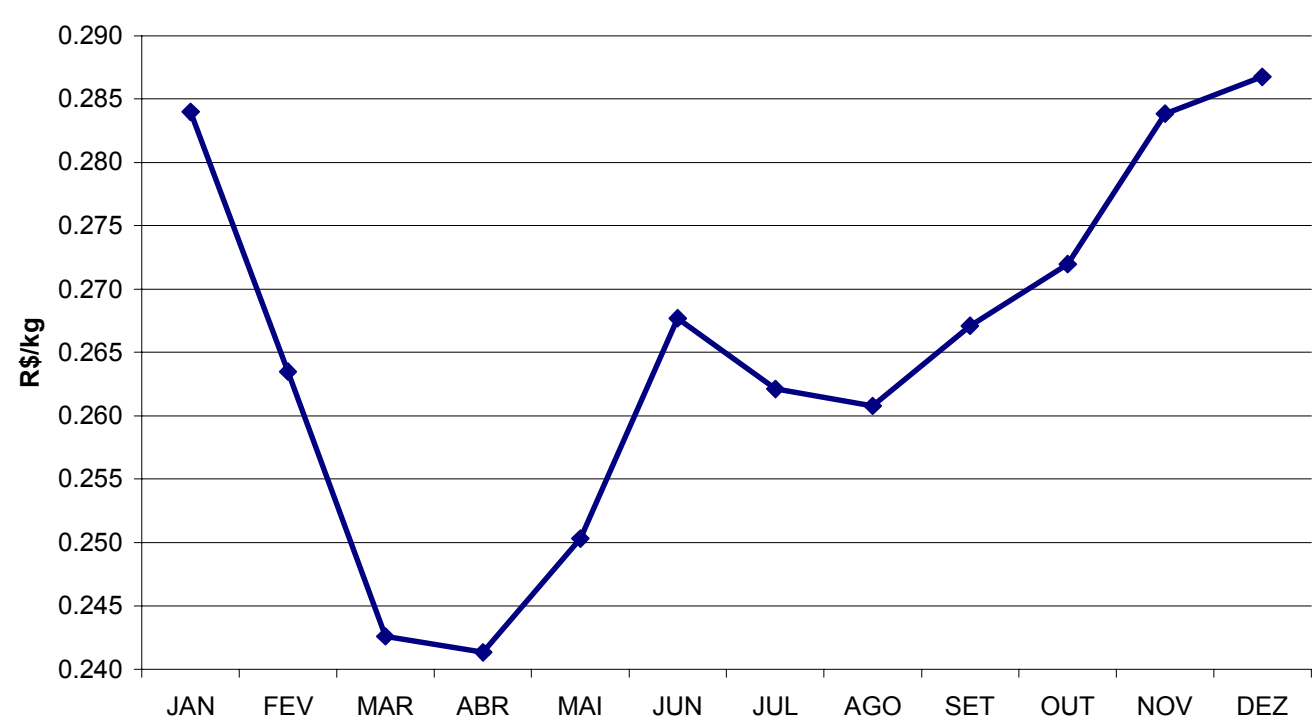

Figura 12: Sazonalidade dos preços do milho demonstrado por regressão linear.

Método utilizado: mínimos quadrados ordinários onde a variável dependente é o preço do milho e as variáveis independentes são 12 variáveis binárias $(0,1)$ representativas dos meses do ano. Elaborado a partir de dados (10 anos) obtidos da FGV - Agroanalysis (2002).

Expondo uma comparação semelhante à abordada no presente trabalho, NOBRE (1982) relacionou o custo da vagem de algaroba e do farelo de trigo (alimento substituído), que estavam idênticos na época da pesquisa. $\mathrm{O}$ autor mostra que há tendências de elevação de preço do farelo de trigo em função da escassez no mercado regional, enquanto a algaroba tende a ter um custo relativamente mais baixo, à medida que sua produção for sendo intensificada pelas empresas rurais. É interessante observar que o preço do milho cotado na época foi $42,86 \%$ acima do preço do farelo de trigo.

Foram calculados os preços relativos FVA/MDPS e, conseqüentemente, FVA/milho, para os quais a substituição pelo FVA seria viável economicamente. Os resultados indicam que, para as rações se equivalerem economicamente, o preço/kg do FVA deve ser 85,95\% e 70,09\% dos preços/kg do MDPS e do milho, respectivamente. Segundo ESPÍNDOLA et al. (1989), a FVA pode substituir o milho desde que o seu preço/kg não ultrapasse $65 \%$ do preço/kg do milho, em rações para coelhos em engorda.

As elevações de preço das rações observadas neste trabalho foram da ordem 
de 4,53, 10,64 e 11,60\% para os níveis de 33, 66 e 100\% de substituição em relação ao tratamento isento de FVA. Em concordância com o presente estudo, o FVA encareceu o custo de alimentação/kg de peso vivo em rações para aves e suínos (PINHEIRO et al., 1993; PINHEIRO et al., 1998). Entretanto os autores atribuem estes resultados ao óleo vegetal utilizado nas rações com a finalidade de ajustar a densidade energética das dietas.

Diferindo destes resultados, ARAÚJO et al. (1990) verificou vantagem econômica para inclusão de FVA até o nível de 20\% em rações para suínos em terminação. Considerou-se no custo espessura de toucinho e conversão alimentar. Em concordância, PINHEIRO et al. (1986) obteve reduções de 9,78, 19,46 e 29,03\% para níveis de 20, 40 e 60\% de substituição, em relação ao tratamento isento de algaroba, ressaltando, todavia, que as diferenças do custo de alimentação por $\mathrm{kg}$ de suíno vivo não foram tão grandes devido ao maior tempo de experimentação obtido pelos animais consumindo FVA.

$\mathrm{O}$ uso de alimentos alternativos é limitado por vezes devido à problemática de custo e produção desses alimentos, visto que, na maioria das vezes não estão em quantidades disponíveis no mercado ainda a ponto de suprir uma possível demanda para incorporá-los as rações animais.

O FVA se encaixa neste contexto já que se sabe da existência de apenas uma empresa (RIOCON $\left.{ }^{\circledR}\right)$, em todo o estado da Bahia, que investe na produção e processamento das vagens. $\mathrm{O}$ custo de transporte e a ausência de concorrência do produto no mercado causam, destarte, elevação do preço final. Atribui-se a esses fatores a inviabilidade atual do uso do farelo por novos investidores.

Considerando que não existe efetivamente distribuição do FVA no estado da Bahia, há grandes possibilidades de redução do preço final à medida que novos pólos de produção, processamento e principalmente distribuição do FVA forem sendo abertos, indicando que o valor do FVA poderá ser inferior ao do milho (talvez ao MDPS também), tornando seu uso em rações viável economicamente. Aliado a isso, as pesquisas sobre a utilização do FVA na nutrição animal devem se intensificar dando o suporte tecno-científico necessário. 


\subsection{CONCLUSÕES}

Cumprindo os objetivos deste trabalho, parece lícito concluir-se que:

1. O farelo de vagem de algaroba (FVA) pode substituir em até $100 \%$ o rolão de milho (MDPS) em rações para eqüinos adultos em manutenção, sem afetar o consumo de MS e a digestibilidade dos nutrientes MS, MO, PB e HCEL;

2. Apesar da substituição progressiva do MDPS pelo FVA proporcionar efeitos indesejáveis nos coeficientes de digestibilidade das fibras (FDN e FDA), reduzindo como conseqüência o aproveitamento energético da ração com altos níveis de FVA, os prejuízos são pequenos, não descartando, portanto, o uso do FVA em até 100\% de substituição;

3. A substituição do MDPS pelo FVA não é viável economicamente, quando se consideram todos os custos envolvidos na colheita, processamento e comercialização deste material; entretanto, em vistas de suas vantagens de aclimatação e disponibilidade sobre o milho, é viável a sua utilização no nordeste na alimentação animal;

4. De acordo com o modelo de avaliação efetuado, a ordem de classificação para utilização dos indicadores é FDAi, CIA e CELi, considerando os conceitos de acurácia, precisão e robustez, e ainda a taxa de recuperação de cada indicador. 


\subsection{IMPLICAÇÕES}

O modelo inovador de avaliação de indicadores desenvolvido neste trabalho, considerando a diferença das estimativas pelo indicador e pela colheita total de fezes (viés), é capaz de oferecer uma análise de fatores que afetam as estimativas de digestibilidade de indicadores, expondo seu real potencial de predição. Dono de baixa complexidade estatística, o modelo pode ser executado sem maiores dificuldades até mesmo na interpretação dos resultados. Outra vantagem seria a padronização do método de avaliação, tornando as comparações entre trabalhos mais verdadeiras.

O levantamento do custo-benefício é uma ferramenta imprescindível para a aplicabilidade prática da pesquisa científica. Contudo há dificuldade de comparação de dados econômicos, principalmente, em função da reduzida informação contida nos trabalhos, no que diz respeito ao aspecto econômico, mas também às especificações técnicas sobre o material avaliado. Estudos mais detalhados são necessários para que se possa comparar e inferir sobre a viabilidade econômica da fonte utilizada.

O FVA pode se tornar um recurso biológico e economicamente viável para a região nordeste, a partir da disseminação e fomento da produção deste material, respaldado na pesquisa científica. 


\section{ANEXO A}

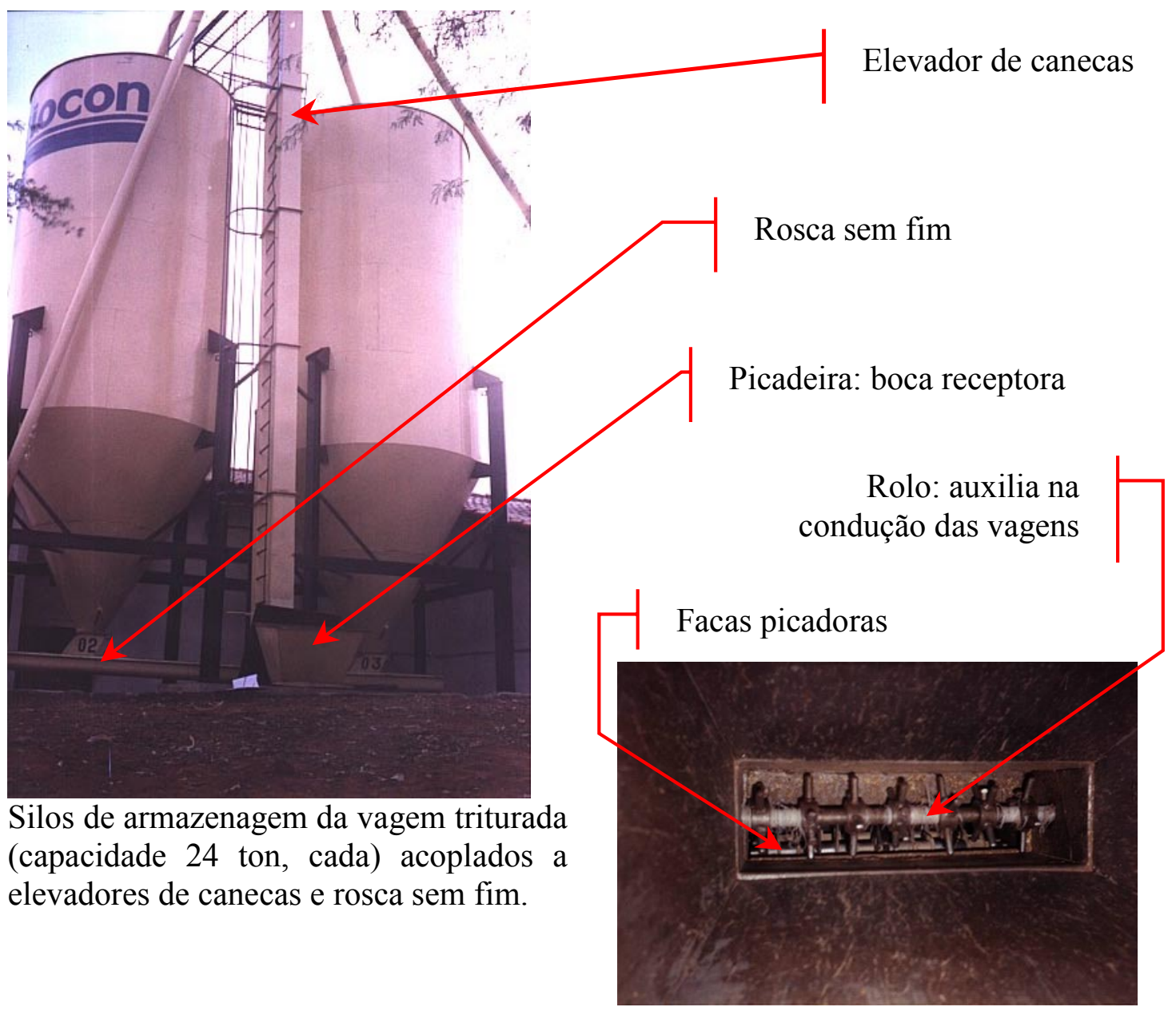

Vista superior da picadeira.

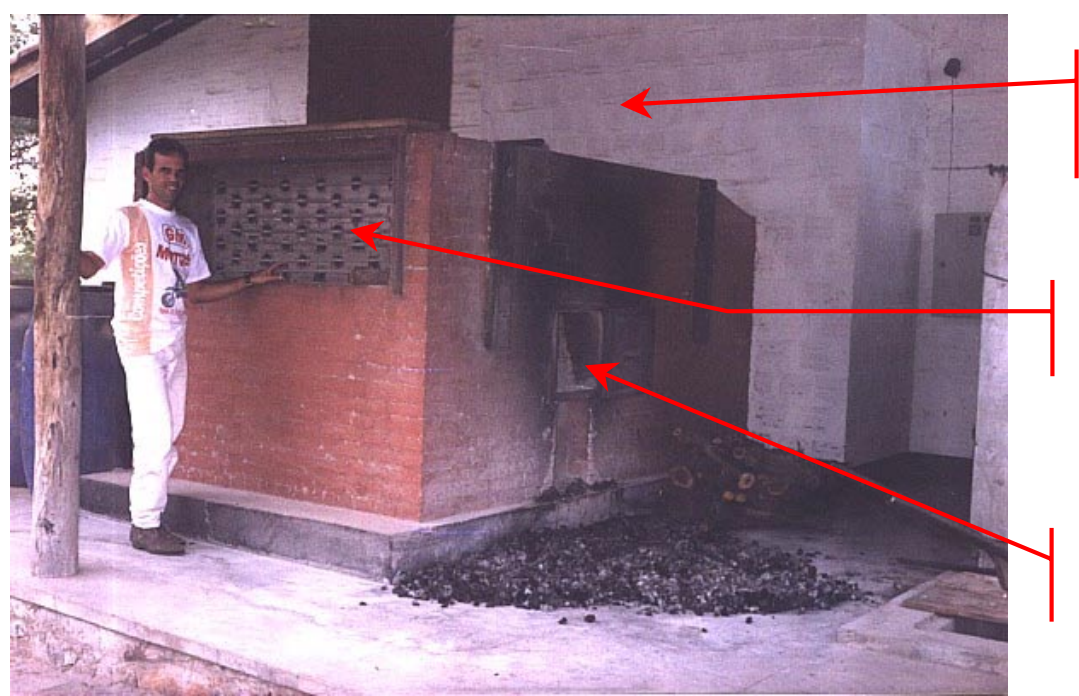

Parede externa da fábrica

Tubos de aço

Receptor de carvão

Fornalha: aquecimento do ar externo. 


\section{ANEXO B}

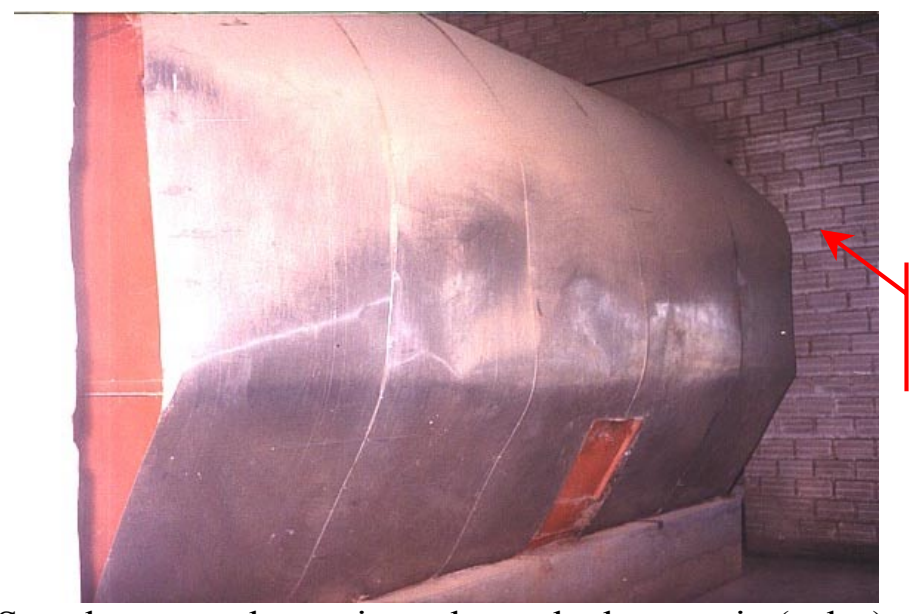

Parede interna da fábrica

Secador: capa de aço impede perda de energia (calor).

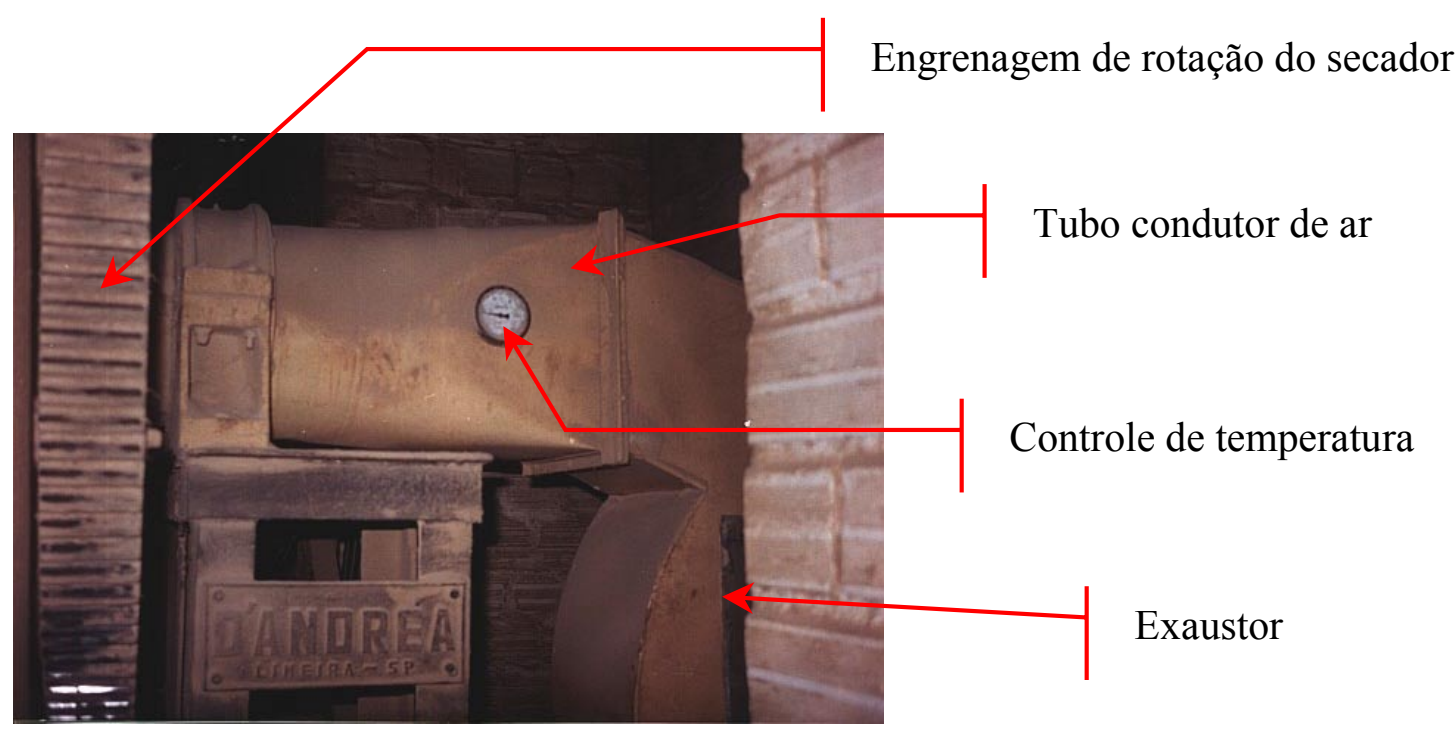

Secador: condução e aquecimento do ar.

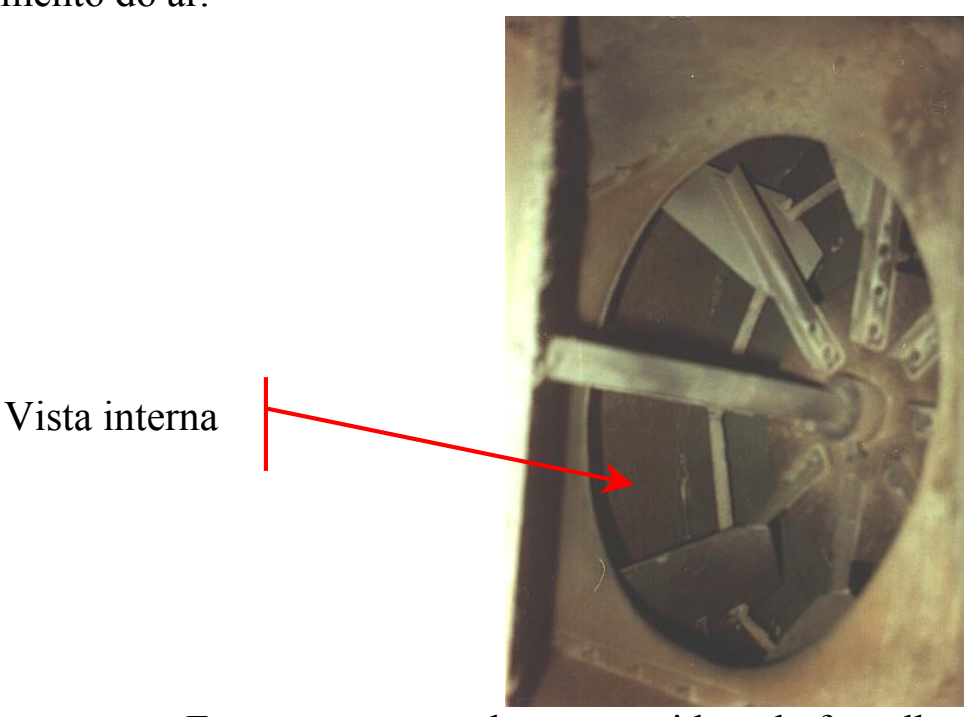

Exaustor: sucção do ar aquecido pela fornalha. 


\section{ANEXO C}

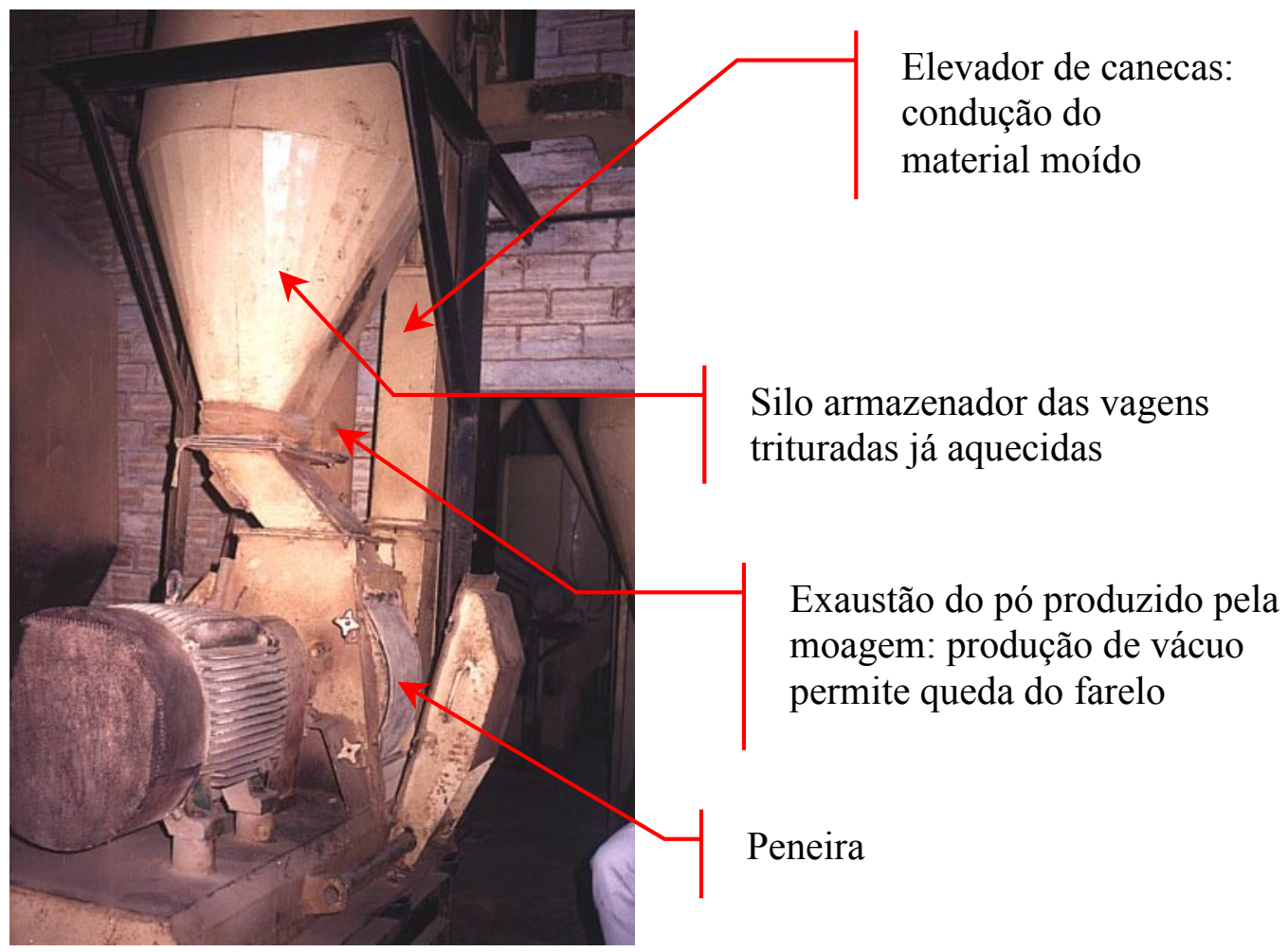

Moinho.

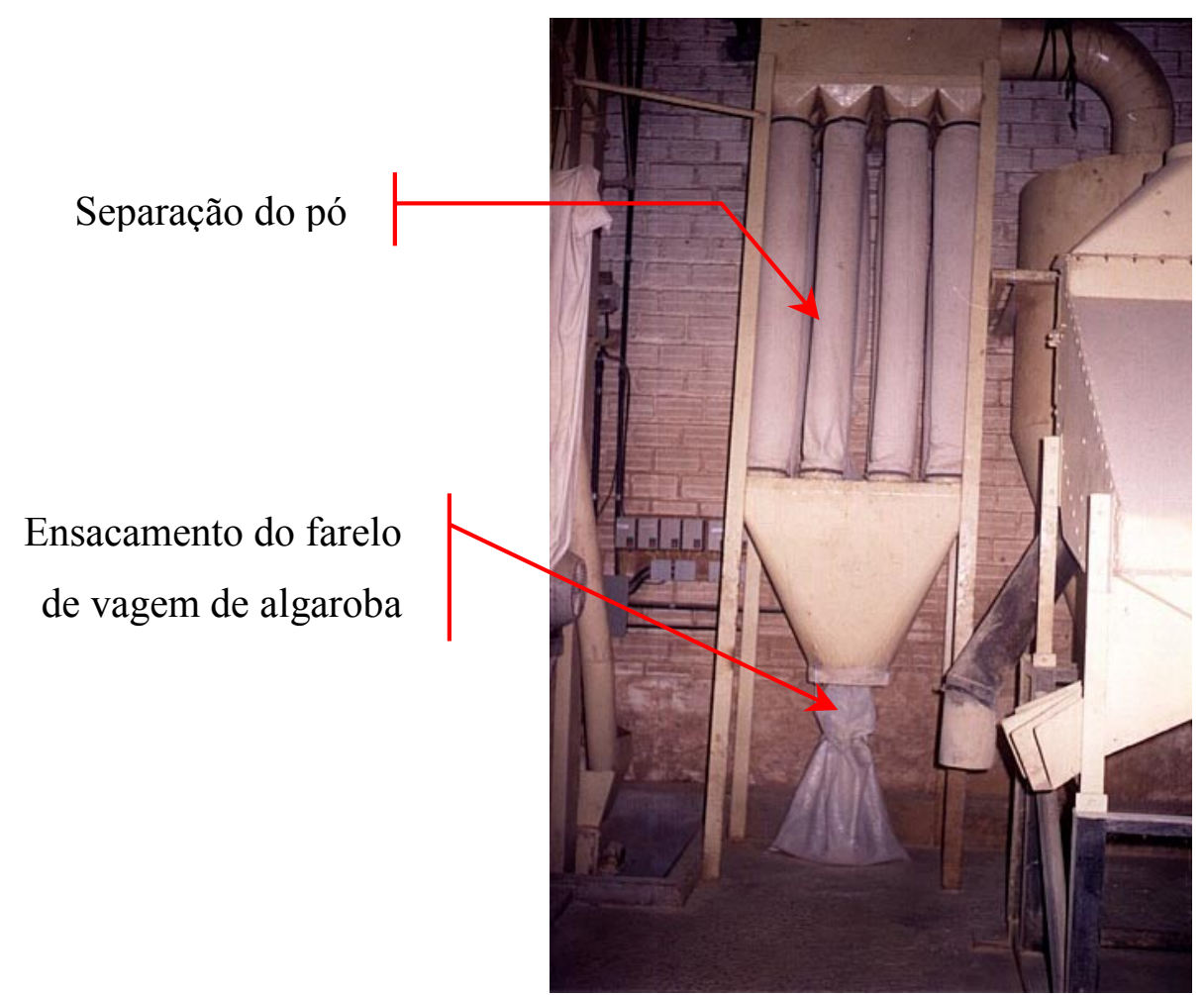

Silo armazenador do farelo de algaroba e ensacador. 


\section{REFERÊNCIAS BIBLIOGRÁFICAS}

ALMEIDA, F.Q.; VALADARES FILHO, S.C.; QUEIROZ, A.C.; SILVA, J.F.C.; ALVARENGA, R.C.; CECON, P.R.; LEÃO, M.I. Fluxo de matéria seca ileal obtido com indicadores internos e externos em eqüinos. Rev. Bras. Zootec., v. 27, n. 3, p. 513-520, 1998a.

ALMEIDA, F.Q.; VALADARES FILHO, S.C.; QUEIROZ, A.C.; LEÃO, M.I.; SILVA, J.F.C.; CECON, P.R.. Digestibilidade aparente e verdadeira pré-cecal e total da proteína em dietas com diferentes níveis protéicos em eqüinos. Rev. Bras. Zootec., v. 27, n. 3, p. 521-529, 1998 b.

ALMEIDA, F.Q.; VALADARES FILHO, S.C.; LEÃO, M.I.; DONZELE, J.L.; SILVA, J.F.C.; CECON, P. R.. Digestibilidade aparente pré-cecal, pós-ileal e total da proteína do milho e do farelo de soja. Rev. Bras. Zootec., v. 27, n. 3, p. 530-537, 1998c.

ALMEIDA, F.Q.; VALADARES FILHO, S.C.; ALMEIDA, M.I.; QUEIROZ, A.C.; DONZELE, J.L.; CECON, P.R.; LEÃO, M.I. Uso de indicadores internos e externo na determinação da digestibilidade aparente de nutrientes em dietas para eqüinos. In: REUNIÃO ANUAL DA SOCIEDADE BRASILEIRA DE ZOOTECNIA, 37., 2000, Viçosa. Anais... Viçosa: SBZ, 2000. /cd-rom/.

ALVARENGA, R.C. Fluxo de matéria seca ileal, metodologias de coleta de digesta e digestibilidade aparente total e parcial em eqüinos. $1996.59 \mathrm{p}$. Dissertação Mestrado - Universidade Federal de Viçosa.

ARAÚJO, K.V. Métodos para determinação da digestibilidade aparente dos nutrientes em eqüinos. 1999. 155 p. Dissertação Mestrado Universidade Federal de Lavras.

ARAÚJO, K.V.; LIMA, J.A.F.; FIALHO, E.T.; MIYAGI, E.S. Comparação entre os indicadores internos e o método de coleta total na determinação da digestibilidade dos nutrientes de alimentos volumosos, em eqüinos. Rev. Soc. Bras. Zoot., v. 29, n. 3, p. 745-751, 2000.

ARAÚJO, L.O.D.; GONÇALVES, L.C.; REZENDE, A.S.C.; RODRIGUEZ N.M.; MAURÍCIO, R.M. Digestibilidade aparente em eqüídeos submetidos a dieta composta de concentrado e volumoso, fornecido com diferentes intervalos de tempo. Arq. Br. Med. Vet. Zoot., v. 49, n. 2, p. 225-237, 1997. 
ARAÚJO, M.C.L.M.; VIANA, S.P.; SANTOS, M.V.F.; SANTOS, M.E.P.; SAMPAIO, F.A. Substituição parcial do milho (Zea mays L.) e farelo de trigo (Triticum aestivum L.) pela farinha de vagem de algaroba (Prosopis Juliflora (S.w.) D.C.) na alimentação de suínos em terminação. In: REUNIÃO ANUAL DA SOCIEDADE BRASILEIRA DE ZOOTECNIA, 27., 1990, Campinas. Anais... Campinas: SBZ, 1990. p. 164.

ASSIS, C.J.C.; BRANDÃO, J.S.; OLIVEIRA, M.O.; SILVA, V.A.L. O fruto triturado da algarobeira na ração final de frangos de corte. In: REUNIÃO ANUAL DA SOCIEDADE BRASILEIRA DE ZOOTECNIA, 27., 1990, Campinas. Anais... Campinas: SBZ, 1990. p. 129.

AZEVÊDO, C.F. Algarobeira na alimentação animal e humana. In: SIMPÓSIO BRASILEIRO SOBRE ALGAROBA, 1., 1982, Natal.. Anais... Natal: EMPARN, 1982. p. 283-299.

BARBOSA, H.P. Valor nutritivo da algaroba (Prosopis juliflora (Sw) D.C.) através de ensaio de digestibilidade em carneiros. 1977.48 p. Dissertação Mestrado - Universidade Federal de Viçosa.

BARROS, N.A.M.T.; QUEIRÓZ FILHO, J.L.. Efeitos na substituição progressiva do melaço por vagens de algaroba (Prosopis Juliflora (S.w.) D.C.) na alimentação de ruminantes. In: SIMPÓSIO BRASILEIRO SOBRE ALGAROBA, 1., 1982, Natal. Anais... Natal: EMPARN, 1982. p. 385-407.

BRANDÃO, J.S; SILVA, V.A.L.; OLIVEIRA, M.O.; BARBOSA, H.P. Algaroba nas rações inicial e final de frangos de corte. In: REUNIÃO ANUAL DA SOCIEDADE BRASILEIRA DE ZOOTECNIA, 26., 1989, Porto Alegre. Anais... Porto Alegre: SBZ, 1989. p. 208.

CAMPOS, J. Tabela para cálculo de rações. 2. ed. Viçosa, MG: Imprensa Universitária / UFV, 1995.

CHURCH, D.C. The ruminal animal digestive physiology and nutrition. 1993. Cap. 9, p. 172- 201.

COCHRAN, R.C; ADAMS, D.C.; WALLACE, J.D.; GALYEAN, M.L. Predicting digestibility of different diets with internal markers: evaluation of four potencial markers. J. Anim. Sci., v. 63, p. 1476-1483, 1986.

CUDDEFORD, D.; HUGUIES, D. A comparison between chromiummordanted hay and acid-insoluble ash to determine apparent digestibitity of a chaffed, molassed hay/straw mixture. Equine Vet. J., v. 22, n. 2, p. 122-125, 1990.

CYMBALUK, N.F. Comparison of forage digestion by cattle and horses. Can. J. Anim. Sci., v. 70, p. 601-610, 1990.

De FOMBELlE, A.; JACOTOT, E.; DROGOUL, C.; BONNEFOY, T; JULLIAND V. Effect of the hay:grain ratio on digestive physiology and 
microbial ecosystem in ponies. In: EQUINE NUTRITION AND PHYSIOLOGY SYMPOSIUM, 16., 1999. Proceedings. p. 151-154.

DEL VALLE, F.R.; ESCOBEDO, M.; MUÑOZ, M.J.; ORTEGA, R.; BOURGES, H. Chemical and nutritional studies on mesquite beans (Prosopis juliflora). J. Food Sci., v. 48, p. 914-919, 1983.

EMPRESA DE ASSISTÊCNICA TÉCNICA E EXTENSÃO RURAL DA BAHIA. Algarobeira: promissora forrageira para a região semi-árida, por José Tavares de Almeida. Salvador, 1983. 52 p. (EMATERBA, Série estudos diversos, 13).

ESPINDOLA, G.B.; GUERREIRO, M.E.F.; SOUZA, A.A.; SILVA, E.F. Substituição do milho pela vagem de algaroba (Prosopis Juliflora) como fonte de energia em rações para coelhos. In: REUNIÃO ANUAL DA SOCIEDADE BRASILEIRA DE ZOOTECNIA, 22., 1985, Balneário Camburiú. Anais... Balneário Camburiú: SBZ, 1985. p. 1.

FARIAS, G.G.M.; BARROS, N.A.M.T. A algarobeira como linha de pesquisa da UFRN: Estudos nutricionais e agronômicos. In: SIMPÓSIO BRASILEIRO SOBRE ALGAROBA, 1., 1982, Natal. Anais... Natal: EMPARN, 1982. p. 380-384.

FERRET, A.; PLAIXATS, J.; CAJA G.; GASA, J.; PRIÓ, P. Using markers to estimate apparent dry matter digestibility, faecal output and dry matter intake in dairy ewes fed Italian ryegrass hay or Alfafa hay. Small Rum. Res., v. 33, p.145-152, 1999.

FUNDAÇÃO GETÚlIO VARGAS. Agroanalisys, 2002. Disponível em: http://www.ipeadata.gov.br/. Data: 11 de julho de 2002.

FRAPE, D. L. Equine nutrition and feeding. London: Longman Scientifc \& Technical, 1986. $373 \mathrm{p}$.

GAZETA MERCANTIL. Agroanalisys, 2002. Disponível em: http://www.ipeadata.gov.br/. Data: 20 de julho de 2002.

GOMES, P. A algarobeira. Rio de Janeiro, RJ: Ministério da Agricultura, 1961. 49 p. il.(SIA 865).

GOMIDE, J.A.; QUEIRÓZ, D.S. Valor nutritivo de leguminosas arbóreas e arbustivas. In: SIMPÓSIO SOBRE USOS MÚLTIPLOS DE LEGUMINOSAS ARBÓREAS E ARBUSTIVAS, 1., 1993, Nova Odessa. Anais... Nova Odessa, 1993. p. 31-62.

GONÇALVES, L.C.; REZENDE, A.S.C.; CARVALHO, M.A.G.; RODRIGUEZ, N.M.; BORGES, A.L.C.C. Digestibilidade aparente em eqüídeos submetidos a três condutas de arraçoamento.I. Matéria seca, proteína bruta e energia bruta. Arq. Br. Med. Vet. Zoot., v. 50, n. 4, p. 421-427, 1998. 
HAAG, H.P. Forragens na seca: algaroba, guandu e palma forrageira. Campinas, SP: Fundação Cargill, 1986. p. 1-24.

HARRIS, D.M.; RODIEK, A.V. Dry matter of diets containing beet pulp fed to horses. In: EQUINE NUTRITION AND PHYSIOLOGY SYMPOSIUM,13., 1993, Gainesville, Florida. Proceedings... p. 100-101.

IATROS: Estatística e pesquisa científica para profissionais de saúde. Acurácia e Precisão, 2002. Disponível em: http://www.vademecum.com.br/iatros. Data: 02 de abril de 2002.

JONKER, J.S.; KOHN, R.A.; ERDMAN, R.A. Using milk urea nitrogen to predict nitrogen excretion and utilization efficiency in lactanting dairy cows. J. Dairy Sci., v. 81, n. 10, p. 2681-2692, 1998.

LaCASHA, P.A.; BRADY, H.A.; ALLEN, V.G.; RICHARDSON, C.R.; POND, K.R. Voluntary intake, digestibility, and subsequent selection of Matua Bromegrass, coastal Bermudagrass, and Alfafa hays by yearling horses. J. Anim. Sci., v. 77, p. 2766-2773, 1999.

LIMA, D.F.; NEGREIROS, A. N.M.; LIMA, C.J.; LEITE, E.L.; FARIAS, G.G.M; SILVA, L.F.; FLORES, H. Avaliação nutricional da farinha da algaroba (Prosopis juliflora): preparo, composição centesimal e toxidez. Arq. Biol. Tecnol. v. 26, n. 2, p. 193, 1983. (Resumo).

LIMA FILHO, H.L.; COSTA, A.N.; CARVALHO REIS, J. Efeito de diferentes níveis de farelo de vagem da algarobeira (Prosopis juliflora $(\mathrm{Sw})$ D.C.) na ração sobre parâmetros produtivos de suínos machos mestiços. Ciên. Vet. Tróp., v. 1, n. 2, p. 81-87, 1998. (Resumo).

MACHADO, H.M. Efeito de diferentes combinações de capim elefante (Penissetum purpureum Schum): cana de açúcar (Saccharum officinarum L.) sobre a digestibilidade, em eqüinos, utilizando diferentes metodologias de determinação. 1992. 71 p. Dissertação Mestrado - Universidade Federal de Viçosa.

MARTIN-ROSSET, W.; DOREAU, M.; BOULOT, S.; MIRAGLIA, N. Influence of level of feeding and physiological state on diet digestibility in light and heavy breed horses. Livestock Prod. Sci., v. 25, p. 257-264, 1990.

MARTIN-ROSSET, W. La alimentacion de los caballos. Paris: INRA, 1990. (versíon española y presentacíon Dr. Antonio Conceillón Martinez, 1993. p 174.)

MEYER, H. Alimentação de Cavalos. São Paulo: Varela, 1995. 303 p.

MILLIKEN, G.A.; JOHNSON, D.E. Analysis of messy data, volume I: designed experiments. Belmont, CA: Lifetime Learning Publication,1984.

MIRAGLIA, N.; BERGERO, D.; BASSANO, B.; TARANTOLA, M.; 
LADETTO, G. Studies of apparent digetibility in horses and the use of internal markers. Livestock Prod. Sci., v. 60, p. 21-25, 1999.

MOORE-COLYER, M.J.S.; LONGLAND, A.C. Intakes and in vivo apparent digestibilities of four types of conserved grass forage by ponies. Anim. Sci., v. 71, p. 527-534, 2000.

NOBRE, F.V. Algaroba na alimentação de vacas em lactação. 1982. 74 p. Dissertação Mestrado - Universidade Federal de Pernambuco, BNB - ETENE. (Título original: "Substituição do farelo de trigo (Triticum vulgare) pelo fruto triturado da algarobeira (Prosopis Juliflora (S.w.) D.C.), na alimentação de vacas em lactação".)

NATIONAL RESEARCH COUNCIL. Nutrient requirements of horses. 5. ed. rev. Washington: National Academy of Scienses, 1989. 100 p.

NOZELLA, E.F. Determinação de taninos em plantas com potencial forrageiro para ruminantes. 2001. 58 p. Dissertação Mestrado CENA/USP, Piracicaba.

OLIVEIRA, A.A.M.A. Digestão total e pré-cecal dos nutrientes em potros fistulados no íleo. 1995. 92 p. Dissertação Mestrado - Universidade Federal de Viçosa.

OLIVEIRA, C.A.A.; ALMEIDA F.Q.; LOPES, B.A.; CORASSA, A.; SANTOS, T.M.; LANA, A.M.Q.; VIEIRA, A.A.; PINTO, L.F. Avaliação da digestibilidade aparente de nutrientes em dietas com diferentes níveis de fibra para eqüinos. In: REUNIÃO ANUAL DA SOCIEDADE BRASILEIRA DE ZOOTECNIA, 38, 2001, Piracicaba. Anais... Piracicaba: SBZ, 2001a. p. 807808.

OLIVEIRA, G.J.C.; LIMA, J.A.F.; ARAÚJO, K.V.; FIALHO, E.T.; BERTECHINI, A.G.; FREITAS, R.T.F.; PÉREZ, J.R.O. Influência da pectina sobre a digestibilidade de nutrientes, em eqüinos. In: REUNIÃO ANUAL DA SOCIEDADE BRASILEIRA DE ZOOTECNIA, 38, 2001, Piracicaba. Anais... Piracicaba: SBZ, 2001b. p. 781-782.

OLIVEIRA, J.N.C.; SILVA, J.H.V.; OLIVEIRA, G.X.; LIMA, J. F.G.; RIBEIRO, M.L.G.; SILVA, E.L.; JORDÃO FILHO, J. Avaliação do farelo de algaroba (Prosopis juliflora (Sw.) D.C.) na alimentação de codornas japonesas (Coturnix coturnix japonica). In: REUNIÃO ANUAL DA SOCIEDADE BRASILEIRA DE ZOOTECNIA, 38, 2001, Piracicaba. Anais... Piracicaba: SBZ, 2001c. p. 892-893.

ORTEGA-NIEBLAS, M.; VÁZQUEZ-MORENO, L.; ROBLESBURGUEÑO, M.R. Protein quality and antinutritional factors of wild legume seeds from the sonoran desert. J. Agric. Food Chem., v. 44, p. 3130-3132, 1996. 
PEARSON, R. A.; MERRITT, J. B. Intake, digestions and gastrointestinal transit time in resting donkeys and ponies and exercised donkeys given ad libitum hay and straw diets. Equine Vet. J., v. 13, n. 5, p. 339-343, 1991.

PENNING, P.D.; JOHNSON, R.H. The use of internal markers to estimate herbage digestibility and intake: 1. potencially indistible cellulose and acid insoluble ash. J. Agri. Sci., v. 100, p. 127-131, 1983 a.

PENNING, P.D.; JOHNSON, R.H. The use of internal markers to estimate herbage digestibility and intake: 2. indistible acid detergent fibre. J. Agri. Sci., v. 100 , p. $133-138,1983$ b.

PINHEIRO, F.M.L.; ESPÍNDOLA, G.B.; FUENTES, M.F.F.; GUERREIRO, M.E.F.; PINHEIRO, M.J.P. Farinha de vagem de algaroba com fonte de energia em rações iniciais para frangos de corte. In: REUNIÃO ANUAL DA SOCIEDADE BRASILEIRA DE ZOOTECNIA, 35., 1998, Botucatu. Anais... Botucatu: SBZ, 1998. p. 180-182.

PINHEIRO, M.J.P.; PIRES, G.S.; COSTA, E.S.; FERNANDES, M.B.; ROSADO, C.A.S. Utilização da vagem de algaroba (Prosopis Juliflora (S.w.) D.C.) na alimentação de suínos em terminação. In: REUNIÃO ANUAL DA SOCIEDADE BRASILEIRA DE ZOOTECNIA, 23., 1986, Campo Grande. Anais... Campo Grande: SBZ, 1986. p. 53.

PINHEIRO, M.J.P.; SOUZA, R.P.; ESPÍNDOLA, G.B. Efeitos da adição de farelo de vagem de algaroba em rações para suínos na fase de terminação. Pesq. Agropec. Bras., v. 28, n. 12, p. 1443-1449, 1993.

RAVILAKA, K.; PATEL, A.M.; MURTHY, K.S.; WADHWANI, K.N. Growth efficiency in feedlot lambs on Prosopis juliflora based diets. Small Rum. Res., v. 16, p. 227-231,1995.

REZENDE, A.S.C.; GONÇALVES, L.C.; CARVALHO, M.A.G.; RODRIGUEZ, N.M.; BORGES, A.L.C.C. Digestibilidade aparente em eqüídeos submetidos a três condutas de arraçoamento. II. frações fibrosas. Arq. Br. Med. Vet. Zoot., v. 50, n. 4, p. 429-434, 1998.

SILVA, A.M.A.; PEREIRA, J.A.A.; COSTA, P.M.A.; MELLO, H.V. Utilização da algaroba (Prosopis Juliflora (S.w.) D.C.) na alimentação de suínos. Rev. Soc. Bras. Zoot., v. 18, n. 2, p. 179-183, 1989a.

SILVA, A.M.A.; PEREIRA, J.A.A.; COSTA, P.M.A.; MELLO, H.V. Valor nutritivo da algaroba (Prosopis Juliflora (S.w.) D.C.), na alimentação de suínos. Rev. Soc. Bras. Zoot., v. 18, n. 2, p. 184-195, 1989b.

SILVA, A.M.A.; RODRIGUES, M.E.; SILVA, J.F. Valor nutritivo da algaroba (Prosopis Juliflora (S.w.) D.C.) na alimentação de coelhos. Vet. e Zoot., São Paulo, v. 2, p. 9-16, 1990a.

SILVA, D.J. Análise de alimentos: métodos químicos e biológicos. 2. ed. 
Viçosa, MG, UFV: Imprensa Universitária, 1990b. 166 p.

SILVA, D.S.; LEITÃO, S.C.; OLIVEIRA FILHO, J.J. Substituição do farelo de trigo (Triticum vulgare Komarnitzky) pelo fruto triturado da algarobeira (Prosopis Juliflora (S.w.) D.C.). In: SIMPÓSIO BRASILEIRO SOBRE ALGAROBA, 1., 1982, Natal. Anais... Natal: EMPARN, 1982. p.361-379.

SILVA, J.H.V.; TOLEDO, R.S.; ALBINO, L.F.T.; RIBEIRO, M.L.G. Composição química e valores energéticos da semente de Cunhã (Clitoria ternatea L.), feijão guandú (Cajanus cajan) e da vagem de algaroba (Prosopis juliflora (Sw.) D.C.) para aves. In: REUNIÃO ANUAL DA SOCIEDADE BRASILEIRA DE ZOOTECNIA, 38, 2001, Piracicaba. Anais... Piracicaba: SBZ, 2001. p. 891-892.

STATISTICAL ANALYSIS SISTEMS INSTITUTE. SAS/STAT ${ }^{\circledR}$ user's guide: version 6. 5. ed. Cary, NC: SAS Institute Inc.,1989. v. 2, 846 p.

SUNVOLD, G.D and COCHRAN, R.C. Technical note: evaluation of acid detergent lignin, alkaline peroxide lignin, acid insoluble ash, and indigestible acid detergent fiber as internal markers for prediction of alfafa, bromegrass, and prairie hay digestibility by beef steers. J. Anim. Sci., v. 69, p. 4951-4955, 1991.

TALPADA, P.M.; SHUKLA, P.C. Influence of feeding Prosopis juliflora pods on digestibility and balances in lactantes cows. Ind. J. An. Sci., v. 58, n. 6, p. 727-730. 1988.

TALPADA, P.M.; SHUKLA, P.C. Utilization of Prosopis juliflora pods in the concentrate supplement of lactating cows. Ind. J. An. Sci., v. 60, n. 9, p. 1121$1123,1990$.

VANKER, S.G.; TALPADA, P.M.; KHANNA, K. Feasibility of utilization of Prosopis juliflora pods in broiler ration. Guj. Agric. Univ. Res. J., v. 23, n. 2, p. 91-96, 1998. (Resumo).

VAN KEULEN, J.; YOUNG, B.A. Evaluation of acid-insoluble ash as a natural marker in ruminant digestibility studies. J. Anim. Sci., v. 44, p. 282$287,1977$.

VERMOREL, M.; VERNET, J.; MARTIN-ROSSET, W. Digestive and energy utilisation of two diets by ponies and horses. Livestock Prod. Sci., v. 51, p. 13-19, 1997. 
APÊNDICE 1

Cálculo demonstrativo para obtenção do preço do MDPS a partir do milho (grão), baseando-se na composição nutricional (PB e EB) e na relação existente entre o preço dos dois insumos no mercado do estado de SP.

Tabela 13: Teor de nutrientes (\% na MS) e preço do MDPS e do milho.

\begin{tabular}{|c|c|c|c|c|c|}
\hline \multicolumn{2}{|l|}{ Alimentos } & PB (\%)* & EB (Mcal/kg)* & & R\$/kg \\
\hline \multicolumn{2}{|c|}{ Milho (grão) } & 8,18 & 4,90 & & 0,36 \\
\hline \multicolumn{2}{|c|}{ MDPS } & 6,96 & 4,10 & $\mathrm{AC}$ & CALCULAR \\
\hline \multicolumn{6}{|c|}{ * Fonte: CAMPOS (1995). } \\
\hline \multicolumn{3}{|l|}{ Proteína Bruta (PB) } & \multicolumn{3}{|c|}{ Energia Bruta (EB) } \\
\hline $1 \mathrm{~kg}$ MDPS $\Rightarrow$ & $6,96 \%$ & & $1 \mathrm{~kg}$ MDPS & $\Rightarrow$ & $4,10 \mathrm{Mcal} / \mathrm{kg}$ \\
\hline \multirow{2}{*}{\multicolumn{2}{|c|}{$\begin{array}{l}\mathrm{X} \text { kg MDPS } \Rightarrow 8,18 \% \\
X=1,18 \mathrm{~kg} \text { de MDPS }\end{array}$}} & & X kg MDPS & $\Rightarrow$ & $4,90 \mathrm{Mcal} / \mathrm{kg}$ \\
\hline & & & $\mathrm{X}=1,20 \mathrm{~kg}$ & $\mathrm{Ml}$ & DPS \\
\hline
\end{tabular}

Relação Nutricional $(\mathrm{PB})=1 \mathrm{~kg}$ Milho $/ 1,18 \mathrm{~kg}$ MDPS $=0,847$

Relação Nutricional $(\mathrm{EB})=1 \mathrm{~kg}$ Milho $/ 1,20 \mathrm{~kg}$ MDPS $=0,833$

A ração (T1) possui $106 \mathrm{~g}$ de $\mathrm{PB}$ e $3.491 \mathrm{kcal}$ por $\mathrm{kg}$ de ração (MS). Deste total o MDPS contribui com $57 \mathrm{~g}$ e $2.716 \mathrm{kcal}$, portanto, 53,73 e 77,81\%, respectivamente.

Ponderando estes valores temos:

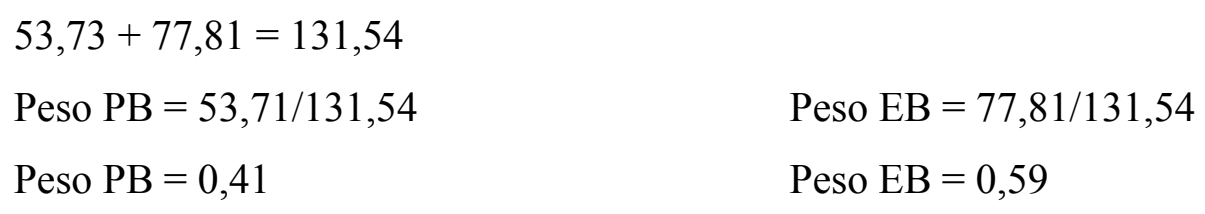

Relação nutricional média $=[(0,847 \times 0,41)+(0,833 \times 0,59)] / 2 \quad=\mathbf{0 , 8 4 5}$ 
Tabela 14: Preços e relações encontradas para MDPS e milho em revendedores de insumos no estado de São Paulo, na $2^{\text {a }}$ quinzena de julho de 2002.

\begin{tabular}{l|cc|c}
\hline \multirow{2}{*}{$\begin{array}{c}\text { Ingrediente } \\
\text { Cidades }\end{array}$} & \multicolumn{2}{|c|}{ R\$/kg } & $\begin{array}{c}\text { Relações } \\
\text { MDPS/Milho }\end{array}$ \\
\cline { 2 - 3 } & MDPS & Milho & 0,81 \\
Mogi Mirim & 0,27 & 0,33 & 0,78 \\
Mogi Mirim & 0,23 & 0,30 & 0,79 \\
Pirassununga & 0,21 & 0,27 & 0,75 \\
Pirassununga & 0,22 & 0,30 & 0,77 \\
Pirassununga & 0,20 & 0,26 & 0,76 \\
Limeira & 0,28 & 0,37 & 0,87 \\
Limeira & 0,26 & 0,30 & $\mathbf{0 , 7 8 9}$ \\
\hline \multicolumn{1}{c}{ Média } & &
\end{tabular}

Média aritmética simples das relações encontradas $=(0,845+0,789) / 2=0,82$

Preço do MDPS segundo relação MDPS/Milho média encontrada:

$\mathrm{R} \$ / \mathrm{kg}$ MDPS $=0,82 \times 0,36 \quad \Rightarrow \quad$ Preço médio/kg MDPS $=\mathbf{R} \$ \mathbf{0 , 2 9}$

Tabela 15: Taxa de câmbio R\$/US\$ comercial - venda média semanal, nos meses de junho e julho de 2002.*

\begin{tabular}{cc}
\hline Período & R\$/US\$ \\
\hline 17 a $21 / 06 / 2002$ & 2,719 \\
24 a $28 / 06 / 2002$ & 2,838 \\
01 a 05/07/2002 & 2,872 \\
08 a $12 / 07 / 2002$ & 2,844 \\
15 a 19/07/2002 & 2,867 \\
22 a 26/07/2002 & 2,949 \\
\hline Fonte: GAZETA MERCANTIL $(2002)$
\end{tabular}


APÊNDICE 2

Tabela 16: Composição química média fecal de éguas consumindo feno de Coast cross e concentrado (60:40\%) com diferentes níveis de FVA em substituição ao MDPS (colheita parcial de fezes).

\begin{tabular}{|c|c|c|c|c|c|c|}
\hline \multirow[b]{2}{*}{ Tratamentos } & \multicolumn{6}{|c|}{ Nutrientes (\% na MS) } \\
\hline & MS total & $M M$ & $P B^{*}$ & $F D N$ & $F D A^{*}$ & $E B(M c a l / k g)^{*}$ \\
\hline T1 & 23,03 & 5,61 & 5,76 & 73,49 & 44,60 & 4,03 \\
\hline $\mathbf{T 2}$ & 24,91 & 5,76 & 5,21 & 71,24 & 45,19 & 3,89 \\
\hline T3 & 20,92 & 4,78 & 5,21 & 70,83 & 46,07 & 3,88 \\
\hline T4 & 24,12 & 5,09 & 4,79 & 72,88 & 48,34 & 3,89 \\
\hline$C V(\%)^{2}$ & 13,83 & 14,78 & 6,26 & 2,15 & 1,86 & 1,72 \\
\hline
\end{tabular}

Substituição do MDPS pelo FVA: T1 = 0\%;T2 = 33\%;T3 = 66\%;T4 = 100\%.

${ }^{2}$ Coeficiente de variação.

* Diferença significativa (teste F) com efeitos linear para PB $\left(y=-0,0088 \mathrm{x}+5,6793, \mathrm{R}^{2}=0,5211, \mathrm{p}=\right.$ $0,0032)$ e para FDA $\left(\mathrm{y}=0,0365 \mathrm{x}+44,234, \mathrm{R}^{2}=0,6783, \mathrm{p}=0,0001\right)$, e quadrático para $\mathrm{EB}(\mathrm{y}=$ $\left.0,00004 x^{2}-0,0051 x+4,0291, R^{2}=0,5658, p=0,0032\right)$. 
APÊNDICE 3

Tabela 17: Média dos coeficientes de digestibilidade (\%) da MS (CDMS), MO (CDMO), PB (CDPB), FDN (CDFDN), FDA (CDFDA), HCEL (CDHCEL) e EB, (CDEB) de éguas alimentadas com feno de Coast cross e concentrado (60:40\%) com diferentes níveis de FVA em substituição MDPS, determinados por colheita total de fezes e indicadores internos.

\begin{tabular}{|c|c|c|c|c|c|c|c|c|}
\hline Trat. & Ind. ${ }^{2}$ & $C D M S$ & CDMO & $C D P B$ & $C D F D A$ & $C D F D N$ & CDHCEL & $C D E B$ \\
\hline \multirow[t]{4}{*}{ T1 } & $\mathrm{CT}$ & 51,53 & 52,61 & 56,28 & 16,50 & 27,48 & 40,00 & 43,30 \\
\hline & FDAi & 51,03 & 51,92 & 59,05 & 17,64 & 27,66 & 39,09 & 41,96 \\
\hline & CELi & 47,62 & 48,57 & 56,53 & 11,91 & 22,62 & 34,84 & 37,92 \\
\hline & CIA & 65,24 & 65,88 & 70,86 & 41,53 & 48,67 & 56,80 & 58,80 \\
\hline \multirow[t]{4}{*}{ T2 } & $\mathrm{CT}$ & 50,05 & 51,10 & 57,65 & 22,26 & 27,67 & 34,43 & 37,70 \\
\hline & FDAi & 45,48 & 46,39 & 58,82 & 12,67 & 23,65 & 37,32 & 36,40 \\
\hline & CELi & 41,96 & 42,93 & 56,16 & 7,03 & 18,72 & 33,29 & 32,31 \\
\hline & CIA & 65,13 & 65,71 & 73,64 & 44,17 & 51,17 & 59,89 & 59,32 \\
\hline \multirow[t]{4}{*}{ T3 } & $\mathrm{CT}$ & 47,66 & 48,72 & 55,38 & 11,24 & 19,52 & 30,17 & 35,20 \\
\hline & FDAi & 49,48 & 49,89 & 61,97 & 16,69 & 27,97 & 42,46 & 41,90 \\
\hline & CELi & 47,14 & 47,58 & 60,19 & 12,83 & 24,65 & 39,84 & 39,22 \\
\hline & CIA & 66,26 & 66,51 & 74,63 & 44,43 & 51,87 & 61,42 & 61,21 \\
\hline \multirow[t]{4}{*}{ T4 } & CT & 47,54 & 48,30 & 58,24 & 7,90 & 20,70 & 37,13 & 37,93 \\
\hline & FDAi & 47,00 & 47,40 & 63,19 & 8,52 & 22,49 & 40,41 & 39,07 \\
\hline & CELi & 47,09 & 47,49 & 63,25 & 8,68 & 22,62 & 40,51 & 39,18 \\
\hline & CIA & 62,23 & 62,52 & 73,76 & 34,82 & 44,76 & 57,51 & 56,59 \\
\hline \multicolumn{9}{|c|}{$C V(\%)^{3}$} \\
\hline & $C T$ & 4,86 & $4,4,62$ & $7 \overline{7,38}$ & 27,33 & 16,61 & 12,65 & 7,17 \\
\hline & $F D A i$ & 4,53 & 4,83 & 2,79 & 26,53 & 13,07 & 10,55 & 6,42 \\
\hline & CEL $i$ & 6,62 & 6,81 & 3,62 & 50,87 & 20,21 & 13,06 & 9,44 \\
\hline & CIA & 2,70 & 2,89 & 2,18 & 5,89 & 5,85 & 6,37 & 3,49 \\
\hline
\end{tabular}

Substituição do MDPS pelo FVA: T1 = 0\%;T2 = 33\%;T3 = 66\%;T4 =100\%.

${ }^{2}$ Colheita total de fezes (CT) e Indicadores: CIA, FDAi e CELi.

${ }^{3}$ Coeficiente de variação. 